\title{
Defect Chemistry and Doping of BiCuSeO
}

\begin{abstract}
Michael Y. Toriyama, ${ }^{a *}$ Jiaxing Qu, ${ }^{b}$ G. Jeffrey Snyder, ${ }^{a}$ Prashun Gorai ${ }^{i *}$
While $p$-type $\mathrm{BiCuSeO}$ is a well-known mid-temperature oxide thermoelectric (TE) material, computations predict that superior TE performance can be realized through $n$-type doping. In this study, we use firstprinciples defect calculations to show that $\mathrm{Cu}$ vacancies are responsible for the native $p$-type self doping; yet, we find that $\mathrm{BiCuSeO}$ is $n$-type dopable under Cu-rich growth conditions, where the formation of $\mathrm{Cu}$ vacancies is suppressed. We computationally survey a broad suite of 23 dopants and find that only $\mathrm{Cl}$ and $\mathrm{Br}$ are effective $n$-type dopants. Therefore, we recommend that future experimental doping efforts utilize phase boundary mapping to optimize the electron concentration and resolve the anomalous $p$ $n-p$ transitions observed in halogen-doped BiCuSeO. The prospects of $n$-type doping, as revealed by our defect calculations, paves the path for rational design of BiCuSeO chemical analogues with similar doping behavior and even better TE performance.
\end{abstract}

\section{Introduction}

p-type $\mathrm{BiCuSeO}$ is one of the most promising thermoelectric (TE) materials for mid-temperature applications, ${ }^{1}$ reaching a maximum TE figure of merit $(z T)$ of $\sim 1.5$ at $823 \mathrm{~K}$ when co-doped with $\mathrm{Ca}$ and $\mathrm{Pb} .^{2}$ The high $z T$ is, in part, due to the high thermopower $(\sim 350 \mu \mathrm{V} / \mathrm{K} \text { at room temperature })^{1}$ as well as the intrinsically low lattice thermal conductivity $(<1 \mathrm{~W} / \mathrm{mK})$ arising from its low Young's modulus ${ }^{3,4}$ and strong anharmonicity. ${ }^{5}$ As a result, $\mathrm{BiCuSeO}$ has attracted, and continues to inspire, a myriad of studies to further improve its TE performance. ${ }^{1,6-8}$

Tuning of the charge carrier (hole, electron) concentrations is needed to optimize the $p$ - or $n$-type TE performance of materials. ${ }^{9}$ For BiCuSeO, doping efforts have almost exclusively been limited to optimizing the hole carrier concentration because the as-grown material is natively $p$-type. Doping with group-2 elements $(\mathrm{Ca}, \mathrm{Sr}$, and $\mathrm{Ba}$ ) has been successful in optimizing $p$-type BiCuSeO. ${ }^{10-13}$ Other efforts to optimize $p$-type BiCuSeO have included doping with group-1 elements such as $\mathrm{Na},{ }^{14-16} \mathrm{~K},{ }^{17,18}$ and $\mathrm{Cs},{ }^{19}$ converging the light and heavy hole bands through alloying with $\mathrm{La},{ }^{20}$ and increasing the electrical conductivity via isovalent $\mathrm{Ag}$ doping. ${ }^{21-23}$ The widespread success of $p$-type $\mathrm{Bi}$ $\mathrm{CuSeO}$ begs the question of whether $\mathrm{BiCuSeO}$ can be doped $n$ type and if it performs equally well as a TE material. We address these questions in this study by computing the formation energies of native defects and 23 dopants in BiCuSeO.

Yang et al. ${ }^{26}$ have shown, using Boltzmann transport theory calculations, that the $z T$ of $n$-type $\mathrm{BiCuSeO}$ can exceed that of $p$ type $\mathrm{BiCuSeO}$ due to the low conduction band effective mass. We also perform an independent analysis based on a semi-empirical model for the quality factor $(\beta)$, which is a measure of the optimized $z T^{24,25,27}$

$$
\beta \propto \frac{\mu m_{\mathrm{DOS}}^{*}{ }^{3 / 2}}{\kappa_{L}} T^{5 / 2}
$$

${ }^{a}$ Northwestern University, Evanston, IL 60208. ${ }^{b}$ University of Illinois at UrbanaChampaign, Urbana, IL 61801. ' Colorado School of Mines, Golden, CO 80401. ${ }^{*} E-$ mail: michaeltoriyama2024@u.northwestern.edu,pgorai@mines.edu

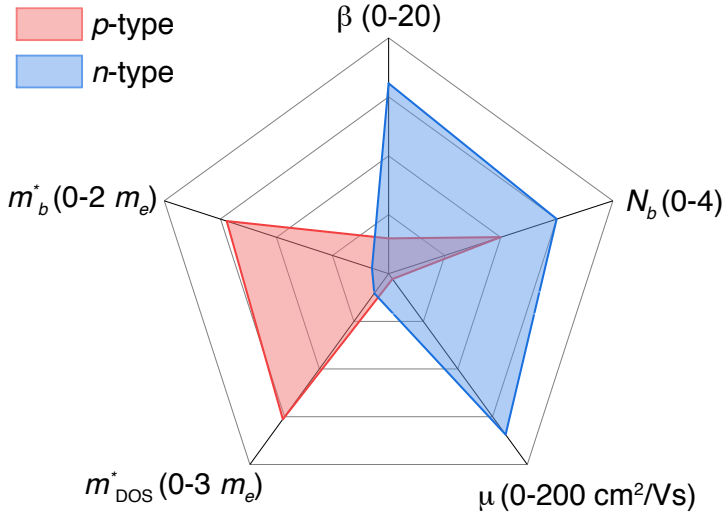

Fig. 1 Comparison of the relevant calculated electronic transport properties of $p$-type (red) and $n$-type (blue) BiCuSeO. $\beta$ is the predicted thermoelectric performance, ${ }^{24,25} \mu$ is the room-temperature mobility in $\mathrm{cm}^{2} / \mathrm{Vs}, N_{b}$ is the band degeneracy, and $m_{b}^{*}$ and $m_{\text {DOS }}^{*}$ are the band and density-of-states (DOS) effective masses, respectively, in units of the free electron mass $\left(m_{e}\right)$.

where $\mu$ is the intrinsic charge carrier mobility at $300 \mathrm{~K}, m_{\mathrm{DOS}}^{*}$ is the density-of-states effective mass, $\kappa_{L}$ is the lattice thermal conductivity at $300 \mathrm{~K}$, and $T$ is the temperature. Parameters that are relevant for electronic transport are summarized in Figure 1. Note that $\kappa_{L}$ is a common denominator for $p$ - and $n$-type $\beta$. We calculate a hole mobility of $6 \mathrm{~cm}^{2} / \mathrm{Vs}$, which is in agreement with the range of experimentally-measured Hall mobilities (4 $\left.22 \mathrm{~cm}^{2} / \mathrm{Vs}\right){ }^{1,28}$ While $m_{\mathrm{DOS}}^{*}$ is higher for $p$-type BiCuSeO suggesting higher thermopower, the combination of lower band effective mass $\left(m_{b}^{*}\right)$, corresponding to a higher carrier mobility, and higher band degeneracy $\left(N_{b}\right)$ predicts a higher TE performance for $n$-type BiCuSeO.

While previous experimental studies have attempted to synthesize $n$-type $\mathrm{BiCuSeO},{ }^{29-32}$ none have been able to successfully demonstrate stable $n$-type conductivity. In particular, doping with halogens $(\mathrm{Cl}, \mathrm{Br}$, and $\mathrm{I})$ is found to undergo an anomalous $p$ $n-p$ transition in the carrier type with increasing temperature, 
which has been attributed to the poor thermal stability of the dopants in BiCuSeO. ${ }^{30,31}$ While this unusual behavior was explained in terms of the chemical bonding strength, ${ }^{31}$ it is not entirely clear why $n$-type doping is difficult - is it due to compensating acceptor-like native defects that limit $n$-type doping or the low solubility of dopants? In addition, a broader pool of plausible $n$-type dopants for $\mathrm{BiCuSeO}$ remains to be explored.

In this study, we assess the $p$ - and $n$-type dopability of BiCuSeO by performing first-principles defect calculations for a comprehensive set of native defects and dopants. We find that $\mathrm{BiCuSeO}$ is natively a $p$-type semiconductor, mainly due to the low formation energies of acceptor copper vacancies $\left(\mathrm{V}_{\mathrm{Cu}}\right)$. Interestingly, we also find that $\mathrm{BiCuSeO}$ is $n$-type dopable under $\mathrm{Cu}$-rich conditions, when the formation of the electron-compensating $\mathrm{V}_{\mathrm{Cu}}$ is most suppressed. Despite the possibility of achieving $n$-type Bi$\mathrm{CuSeO}$, out of the 23 dopants that are considered in this study, we find that only doping with halogens $(\mathrm{Cl}, \mathrm{Br})$ achieve free electron concentrations of $\sim 10^{18} \mathrm{~cm}^{-3}$. Accordingly, while native electron-compensating acceptor defects can be suppressed under appropriate growth conditions, the solubility of dopants is the primary limiting factor to achieving $n$-type conductivity in BiCuSeO. As a result, we stress that thermodynamic growth conditions and the resulting competing impurity phases of doped samples be carefully analyzed when pursuing $n$-type BiCuSeO.

\section{Computational Methods}

The first-principles density functional theory (DFT) calculations were performed using the Vienna Ab initio Simulation Package (VASP). ${ }^{33,34}$ The core and valence electrons were treated with the projector augmented wave method. ${ }^{35,36}$ The plane-wave energy cutoff was set to $340 \mathrm{eV}$ for all calculations except for dopant calculations involving $\mathrm{F}$, where we instead use a larger cutoff of $540 \mathrm{eV}$. A rotationally invariant Hubbard $U$ on-site correction ${ }^{37}$ was applied to $\mathrm{Cu}(U=5 \mathrm{eV}) .{ }^{38}$

\subsection{Structure Relaxation}

$\mathrm{BiCuSeO}$ has ZrSiCuAs-type layered structure with space group P4/nmm (number 129), shown in Figure S1(a). Since BiCuSeO has a layered crystal structure, we found that structure relaxation with the generalized gradient approximation (GGA) of PerdewBurke-Ernzerhof (PBE) ${ }^{39}$ overestimated the $c$ axis by 1.5\% (Table $\mathrm{S} 1$ in the supplementary information). It is well known that the GGA functional underbinds the layers in quasi-2D structures such as $\mathrm{BiCuSeO}$ due to the absence of long-range van der Waals interactions. ${ }^{40}$ The crystal structure relaxed with the vdW-corrected optB86 exchange-correlation functional $(\mathrm{vdW}+U){ }^{41}$ yielded lattice constants in much better agreement with experimental values $(<0.1 \%$ error, see Table S1) compared to GGA $+U$.

\subsection{Electronic Structure}

The electronic structure of $\mathrm{BiCuSeO}$ was calculated using the GGA $+U$ functional on the crystal structure relaxed using $\mathrm{vdW}+U$, as suggested by Marom et al. ${ }^{42}$ The electronic structure was calculated using the tetrahedron method for $k$-point integrations, ${ }^{43}$ using a dense $12 \times 12 \times 6 \Gamma$-centered $k$-point mesh. It is well-known that the band gap is underestimated with the GGA functional, which can affect the calculated defect formation energies and charge carrier concentrations. We address the band gap issue by applying shifts to the band edge positions based on GW quasiparticle energy calculations, ${ }^{44-48}$ which resulted in the valence (conduction) band edge shifts of $-0.36(+0.08)$ eV relative to the GGA band edges. We also included relativistic spin-orbit coupling (SOC) effects due to the presence of heavy Bi atoms, from which we obtained valence (conduction) band edge shifts of +0.02 (-0.31) eV. The "corrected" band gap of $0.88 \mathrm{eV}$ is in close agreement with the experimental value of $\sim 0.8 \mathrm{eV} .{ }^{49}$ The band structure calculated along the high-symmetry $k$-point paths ${ }^{50,51}$ is shown in Figure S2.

\subsection{Defect Energetics}

The defect energetics were calculated using the standard supercell approach. ${ }^{52,53}$ A $3 \times 3 \times 2$ supercell of $\mathrm{BiCuSeO}$, containing 144 atoms, was considered for all defect formation energy calculations. We calculated the total energies of the host and defected supercells using a two-step process: first, we relaxed the ionic positions using the optB86 vdW-corrected functional with a $3 \times 3 \times 2$ $\Gamma$-centered $k$-point mesh, and afterwards calculated the total energy of the vdW-relaxed supercell using a self-consistent GGA $+U$ calculation with a $6 \times 6 \times 4 \Gamma$-centered $k$-point mesh.

The formation energies of defects were calculated as

$$
\Delta E_{D^{q}}=E_{D^{q}}-E_{\mathrm{host}}+\sum_{i} n_{i} \mu_{i}+q E_{\mathrm{F}}+E_{\mathrm{corr}}
$$

where $\Delta E_{D^{q}}$ is the formation energy of defect $D$ in charge state $q, E_{D^{q}}$ and $E_{\text {host }}$ are the total energies of the supercell with and without the defect respectively, and $E_{\mathrm{F}}$ is the Fermi energy.

The chemical potential $\mu_{i}$ of element $i$ is expressed relative to a reference state $\left(\mu_{i}^{0}\right)$ such that $\mu_{i}=\mu_{i}^{0}+\Delta \mu_{i}$. A certain number of atoms $\left(n_{i}\right)$ of element $i$ are added $\left(n_{i}<0\right)$ or removed $\left(n_{i}>0\right)$ from the host supercell to form the defect $D$. The reference chemical potentials $\mu_{i}^{0}$ were determined by fitting them to a set of experimentally-measured formation enthalpy ${ }^{54,55}$ (under standard conditions) of several compounds in the $\mathrm{Bi}-\mathrm{Cu}$ Se-O quaternary chemical space. ${ }^{56-61}$ The fitted values of $\mu_{i}^{0}$ of all elements considered in this study are tabulated in Table S2. The bounds on $\Delta \mu_{i}$ are set by thermodynamic phase stability conditions; specifically, $\Delta \mu_{i}$ should satisfy the constraint $\Delta \mu_{\mathrm{Bi}}+\Delta \mu_{\mathrm{Cu}}+\Delta \mu_{\mathrm{Se}}+\Delta \mu_{\mathrm{O}}=\Delta H_{f}^{\mathrm{BiCuSeO}}$, where $\Delta H_{f}^{\mathrm{BiCuSeO}}$ is the formation enthalpy of BiCuSeO. Also, $\Delta \mu_{\mathrm{Bi}}, \Delta \mu_{\mathrm{Cu}}, \Delta \mu_{\mathrm{O}}$, and $\Delta \mu_{\mathrm{Se}}$ values should be such that other competing phases are unstable relative to $\mathrm{BiCuSeO}$. In experiments, $\Delta \mu_{i}=0$ corresponds to $i$-rich growth conditions and a large negative value of $\Delta \mu_{i}$ represents $i$ poor growth conditions.

Corrections to the defect formation energy arising from finitesize effects were included in $E_{\text {corr }}$, following the methodology of Lany and Zunger. ${ }^{52,62}$ The finite-size corrections include: (i) alignment of the average electrostatic potential between the neutral, defect-free host supercell and the charged, defected supercells, (ii) removal of artificial, long-range interactions between the image charges in periodic supercells that are charged, and (iii) 
correction for Moss-Burnstein-type band filling ${ }^{63}$ due to shallow defects.

The pylada-defects software ${ }^{64}$ was used in this work for automating the point defect calculations, including the creation of defect supercells and calculation of finite-size corrections. The formation energies of native point defects (vacancy, anti-site, interstitial) and dopants (substitutional, interstitial) were calculated in charge states $q=-3,-2,-1,0,+1,+2$, and +3 . Additional charge states were considered where necessary. The plausible sites that can accommodate interstitial defects were determined by a Voronoi tessellation scheme implemented in pyladadefects. ${ }^{64}$ The lowest-energy interstitial site was determined from the total energy of the interstitial configurations in the neutral charge state. The structures of $\mathrm{Cu}_{\mathrm{i}}^{1+}$ and $\mathrm{O}_{\mathrm{i}}^{0}$ are shown in Figure S1. The optimized defect structures are available in a public repository. ${ }^{65}$

\subsection{Charge Carrier Concentrations}

The free charge carrier concentrations were calculated by solving for the equilibrium Fermi energy $\left(E_{\mathrm{F}}^{\mathrm{eq}}\right)$ satisfying the charge neutrality condition, which is expressed as

$$
\sum_{D^{q}}\left[q N_{D} e^{-\Delta E_{D^{q}} / k_{B} T}\right]+p-n=0
$$

where the sum runs over all defects $D^{q}, N_{D}$ is the site concentration where defect $D$ can be formed, $k_{B}$ is the Boltzmann constant, $T$ is the temperature, and $p$ and $n$ are the hole and electron concentrations, respectively. We assume that the defects formed at the synthesis temperature are kinetically "frozen in"; that is, when a material is quenched to lower temperatures, the defect concentrations reflect the defect thermodynamics at the synthesis temperature. Therefore, in Eq. 3, we use the synthesis temperature (not to be confused with the transport measurement temperature) to compute the net free carrier concentration. This commonly used assumption, emanating from the fact that most defects are not mobile at lower temperatures, provides accurate predictions of free carrier concentrations in agreement with experiments. ${ }^{45,46,66}$ The free carrier concentrations $p$ and $n$ are calculated as

$$
\begin{aligned}
& p=\int_{-\infty}^{\mathrm{VBM}} g(E)[1-f(E)] d E \\
& n=\int_{\mathrm{CBM}}^{\infty} g(E) f(E) d E
\end{aligned}
$$

where $f(E)$ is the Fermi-Dirac distribution. The density of states $g(E)$ was calculated using DFT with a $\Gamma$-centered $12 \times 12 \times 6 k$ point grid ${ }^{67}$ and the tetrahedron method for Brillouin zone integration (Section 2.2).

\section{Results and Discussion}

\subsection{Native Point Defects in BiCuSeO}

Our convex hull analysis suggests that there are 12 distinct fourphase stability regions of $\mathrm{BiCuSeO}$ in the quaternary equilibrium Bi-Cu-Se-O phase space. Each stability region is defined by the equilibrium between $\mathrm{BiCuSeO}$ and three other competing phases. (a) most Cu-poor

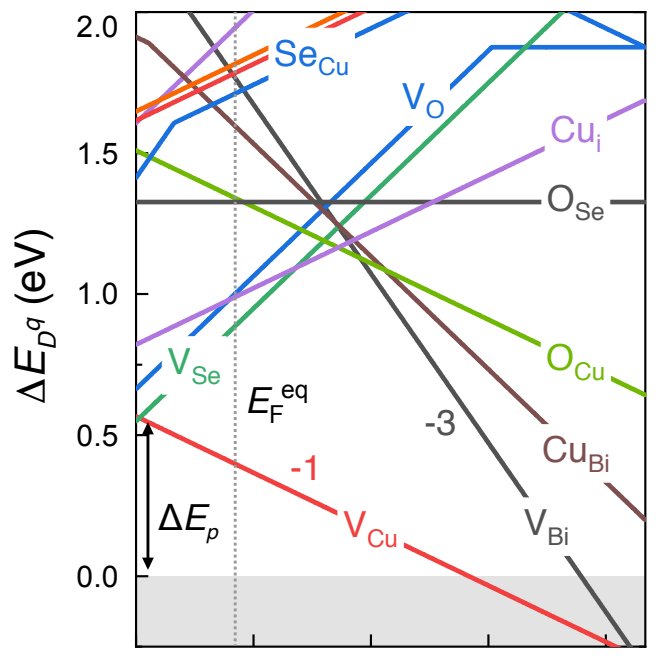

(b) most Cu-rich

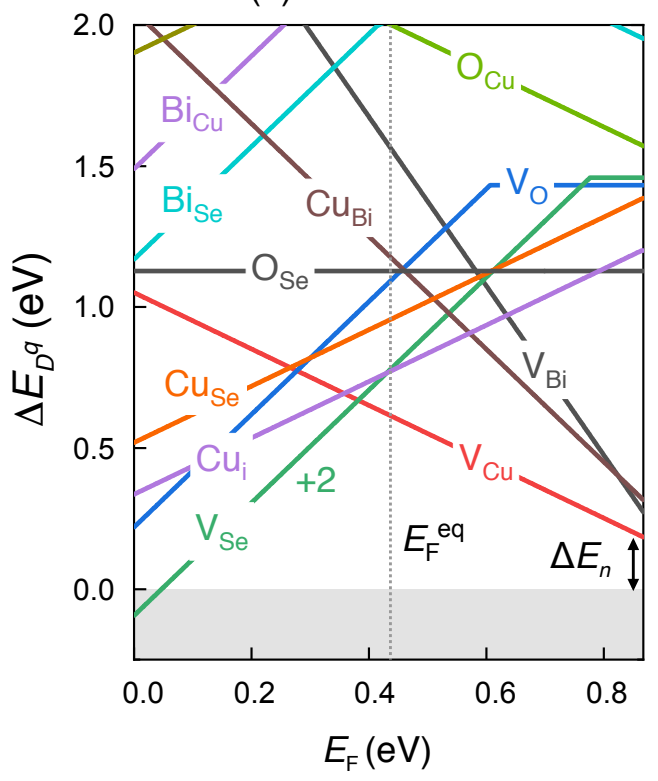

Fig. 2 Formation energies of native defects in $\mathrm{BiCuSeO}$ are shown for the (a) most $\mathrm{Cu}$-poor growth condition (equilibrium with $\mathrm{Se}, \mathrm{Bi}_{2} \mathrm{O}_{3}$, and $\mathrm{Bi}_{2} \mathrm{O}_{2} \mathrm{Se}$ ) with the highest free hole concentration of $1.3 \times 10^{20} \mathrm{~cm}^{-3}$, and (b) most Cu-rich conditions (equilibrium with $\mathrm{Bi}, \mathrm{Cu}_{2} \mathrm{O}$, and $\mathrm{Cu}_{2} \mathrm{Se}$ ) with lowest free hole concentration of $5.1 \times 10^{18} \mathrm{~cm}^{-3}$, assuming a synthesis temperature of $973 \mathrm{~K}$. The equilibrium Fermi energy is marked by the dotted vertical lines. Under Cu-poor conditions, BiCuSeO is natively a degenerate $p$-type semiconductor with scope for higher hole doping because of the large $p$-type dopability window $\left(\Delta E_{p}\right)$. Under the most $\mathrm{Cu}$-rich condition, $\mathrm{BiCuSeO}$ has an $n$-type dopability window $\left(\Delta E_{n}\right)$ suggesting the possibility of $n$-type doping. The formation energies of all native defects are shown in Figure S3 in the supplementary information.

In the chemical potential space, these phase stability regions (Table S3) correspond to different elemental chemical potentials $\left(\mu_{i}\right.$ in Eq. 2) and, as a result, different defect and carrier concentrations. In principle, the elemental chemical potentials can be controlled by modifying the growth conditions (e.g., Cu-poor vs. Curich) and by performing phase boundary mapping, ${ }^{66,68}$ in which 
the competing (impurity) phases of a material are explicitly determined to gauge the thermodynamic state of the material. We find that $\mathrm{BiCuSeO}$ is in thermodynamic equilibrium with $\mathrm{Se}, \mathrm{Bi}_{2} \mathrm{O}_{3}$ and $\mathrm{Bi}_{2} \mathrm{O}_{2} \mathrm{Se}$ under the most Cu-poor growth condition, and in equilibrium with $\mathrm{Bi}, \mathrm{Cu}_{2} \mathrm{O}$, and $\mathrm{Cu}_{2} \mathrm{Se}$ under the most Cu-rich condition (Table S3).

Our defect calculations show that $\mathrm{BiCuSeO}$ is natively a $p$ type semiconductor under $\mathrm{Cu}$-poor and $\mathrm{Cu}$-rich growth conditions due to the low formation energy of the acceptor-like $\mathrm{Cu}$ vacancy $\left(\mathrm{V}_{\mathrm{Cu}}\right)$, as shown in Figure 2. The relevant defects are those with the lowest formation energy at the equilibrium Fermi energy $\left(E_{\mathrm{F}}^{\mathrm{eq}}\right)$, which is determined self-consistently by solving the charge neutrality condition (Section 2.4). In Figure 2, $E_{\mathrm{F}}^{\mathrm{eq}}$ (marked with a dotted vertical line) is calculated assuming the typical synthesis temperature of $973 \mathrm{~K}$. It has been shown experimentally that decreasing the $\mathrm{Cu}$ content in $\mathrm{BiCu}_{1-x} \mathrm{SeO}$ increases the hole carrier concentration. ${ }^{69}$ This can be explained by the low formation energy of the acceptor defect $\mathrm{V}_{\mathrm{Cu}}$ under $\mathrm{Cu}$-poor growth conditions, which is consistent with our predictions. Therefore, our results show that synthesizing $\mathrm{BiCuSeO}$ under $\mathrm{Cu}$-poor growth conditions is a practical method to tune the hole carrier concentration due to the low formation energies of $\mathrm{V}_{\mathrm{Cu}}$.

The free hole concentration is maximized when $\mathrm{BiCuSeO}$ is grown under Cu-poor conditions (Figure 2a). Under the most Curich conditions, the hole concentration is minimized (Figure $2 \mathrm{~b}$ ) due to charge compensation by electrons generated by the formation of Se vacancies $\left(\mathrm{V}_{\mathrm{Se}}\right)$ and $\mathrm{Cu}$ interstitials $\left(\mathrm{Cu}_{\mathrm{i}}\right)$. In contrast, hole compensation does not occur under $\mathrm{Cu}$-poor conditions due to the higher formation energies of $\mathrm{V}_{\mathrm{Se}}$ and $\mathrm{Cu}_{\mathrm{i}}$. Our predicted free hole concentrations in native $\mathrm{BiCuSeO}$ range from $5.1 \times 10^{18}$ $\mathrm{cm}^{-3}$ (Cu-rich) to $1.3 \times 10^{20} \mathrm{~cm}^{-3}$ (Cu-poor), in agreement with experimental measurements as shown in Figure 3.

A material is considered $p$-type dopable if the formation energy of the lowest-energy native donor defect is positive for all values of $E_{\mathrm{F}}$ within the band gap. In such a case, holes generated by a sufficiently soluble acceptor dopant are not compensated significantly by the electrons created by the native donor defect. Accordingly, a $p$-type dopability window $\left(\Delta E_{p}\right)$ may be defined at the VBM (Figure 2a), where a large positive $\Delta E_{p}$ indicates a highly $p$-type dopable material while a negative window would suggest difficulty in $p$-type doping. Similarly, an $n$-type dopability window $\left(\Delta E_{n}\right)$ is set by the formation energy of the lowest-energy native acceptor defect at the CBM and provides a measure of the potential for $n$-type doping. Under the most Cu-poor condition (Figure 2a), $\Delta E_{p}$ is $>0.5 \mathrm{eV}$. In fact, we find $\mathrm{BiCuSeO}$ has a positive $\Delta E_{p}$ in 10 out of the 12 phase stability regions, which is not surprising considering the widespread success in $p$-type doping of BiCuSeO e.g., with group- 2 alkaline-earth elements. $4,10-13,71-73,76$

Perhaps the less anticipated result of our defect calculations is the prospect of doping BiCuSeO $n$-type, as evidenced by a positive $\Delta E_{n}$ under Cu-rich growth conditions (Figure 2b) where the formation of the electron-compensating acceptor $V_{\mathrm{Cu}}$ is most suppressed. As such, it may be possible to realize $n$-type doping of $\mathrm{BiCuSeO}$ provided a sufficiently soluble dopant can be found. In the following section, we discuss 23 different $p$ - and $n$-type candidate dopants and the necessary growth conditions to maximize

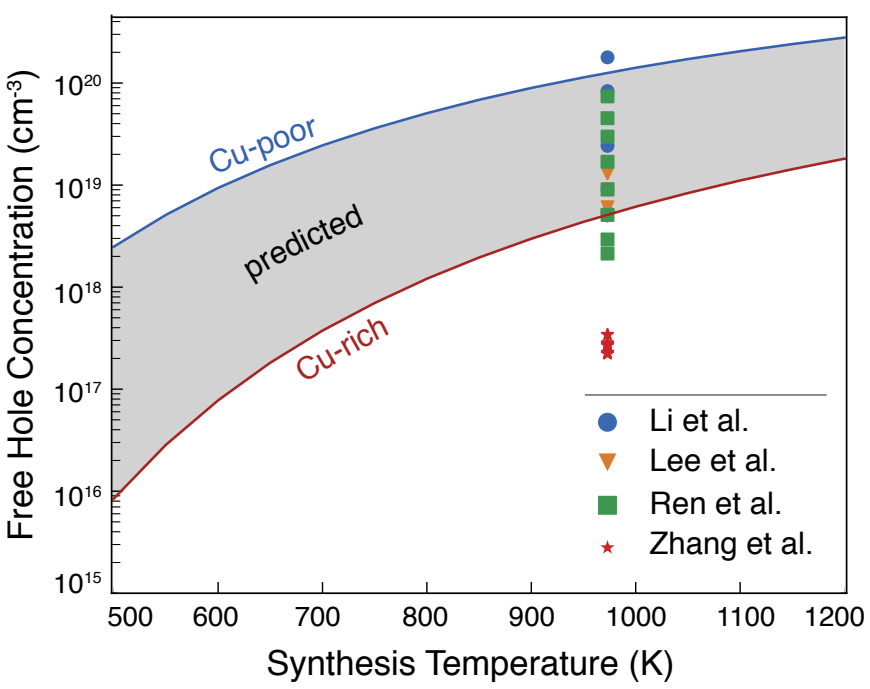

Fig. 3 Shaded area is the predicted range of free hole carrier concentrations in native $\mathrm{BiCuSeO}$ as a function of synthesis temperature. The highest (lowest) free hole concentrations are achieved under the most $\mathrm{Cu}$-poor (Cu-rich) growth conditions. Experimentally measured hole carrier concentrations are shown as colored symbols $(\mathrm{Li}$ et al., ${ }^{3}$ Lee et al., ${ }^{17}$ Ren et al.. ${ }^{70}$ Zhang et al. ${ }^{31}$ ). The predicted range of hole concentrations are in fair agreement with experiments.

the corresponding free carrier concentrations.

\subsection{Dopants in BiCuSeO}

We calculate the formation energies of 23 plausible $p$ - and $n$-type dopants for $\mathrm{BiCuSeO}$ and the resulting free carrier concentrations generated by each dopant. All dopants are considered as substitutional defects, and some are additionally considered as interstitials where appropriate (e.g., Li). We calculate the carrier concentrations in all five-phase equilibrium regions where $\mathrm{BiCuSeO}$ is stable in the quinary Bi-Cu-Se-O-dopant phase space. The equilibrium phases and the corresponding free carrier concentrations in each phase region are listed in Tables S4 - S26. For each of the 23 dopants, the range of achievable free carrier concentrations are shown in Figure 4 and compared to available data from experimental doping studies.

Ideally, a dopant will extend the achievable range of carrier concentrations beyond what is attained through native selfdoping. However, there are several factors that may limit the efficiency of a dopant. First, the solubility of a dopant is the critical limiting factor; if the formation energy of the substitutional (or interstitial) dopant is high compared to the native defects i.e., solubility of the dopant is low, then the concentration of free carriers generated by the dopant is insignificant compared to the native self-doped carrier concentration. Second, free carriers generated by the dopant may be charge compensated by the carriers of the opposite type (electrons, holes) generated by the native defects (donors, acceptors). Such a scenario occurs when the formation energy of the compensating native defect is low and is one of the central reasons why a dopability window (e.g., $\Delta E_{p}$ and $\Delta E_{n}$ in Figure 2) is necessary (but not sufficient) to realize the desired doping. Finally, certain dopants may form both substitutional (or 


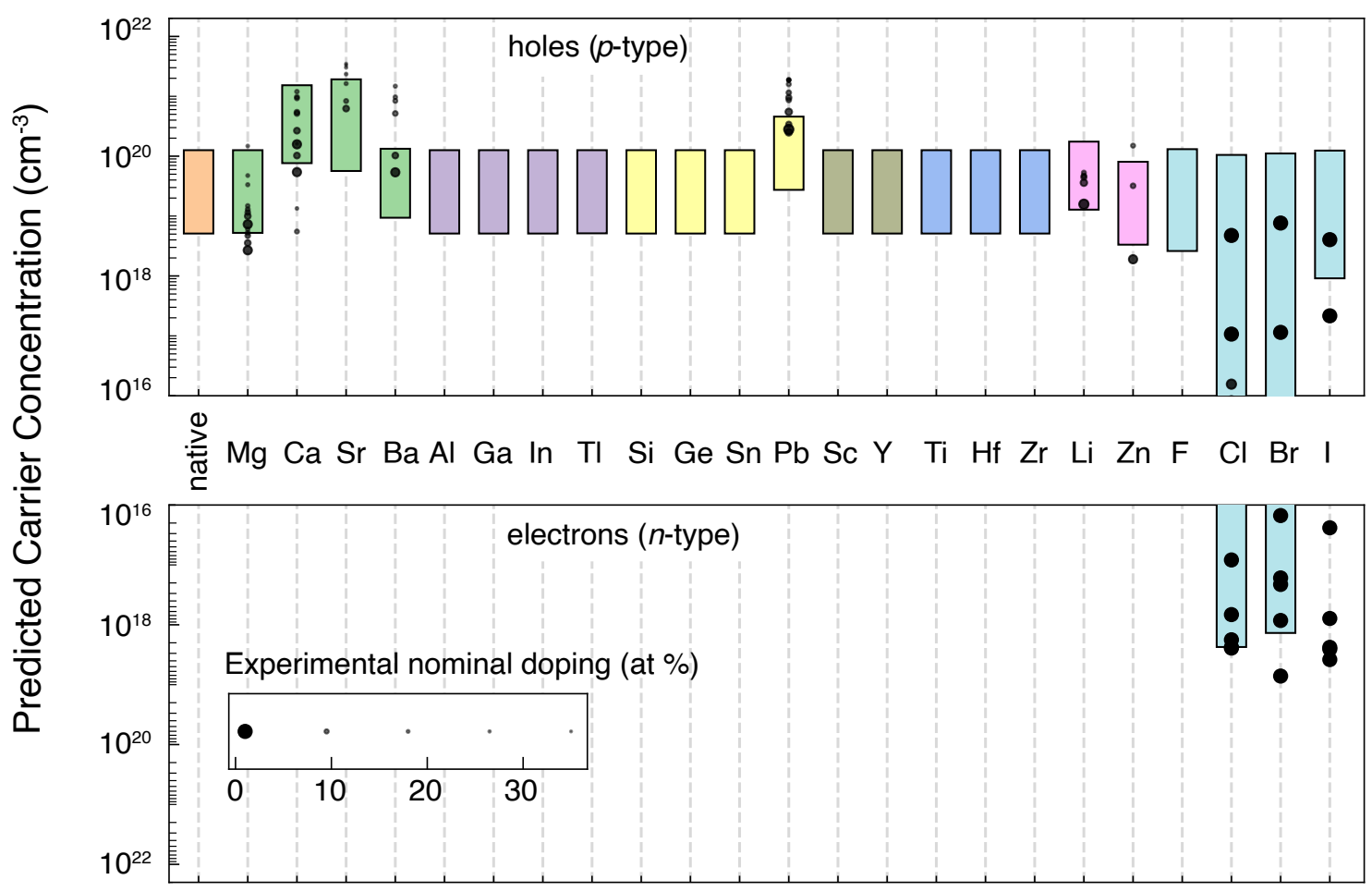

Fig. 4 Predicted range of free carrier concentrations for native defects and 23 dopants in BiCuSeO. The typical synthesis temperature of $973 \mathrm{~K}$ is used to calculate the carrier concentrations. The free hole ( $p$-type) and electron ( $n$-type) concentrations are shown in the top and bottom panels, respectively. Experimentally measured carrier concentrations are shown with solid black circles, $4,10-12,28,29,31,70-75$ where the size of the marker corresponds to the nominal doping concentration ranging from 1 to 35 atomic \%, as shown in the inset. Larger circles correspond to lower doping concentrations, whereas smaller circles to higher doping concentrations.

interstitial) acceptor and donor defects depending on the substituting site in the structure, such that the dopant generated electrons and holes self-compensate.

We find that the primary factor limiting $n$-type doping of Bi$\mathrm{CuSeO}$, despite being $n$-type dopable under $\mathrm{Cu}$-rich growth conditions, is the low solubility of dopants, as discussed in detail in Section 3.2.2. Many of the dopants considered in this study exhibit high formation energies in BiCuSeO, even under the most dopant-rich thermodynamic conditions.

\subsection{1 p-type Dopants}

For the purposes of benchmarking our dopant calculations, we first consider a series of well-known $p$-type dopants in BiCuSeO, the group-2 alkaline-earth metals $\left(\mathrm{Mg},{ }^{71,72} \mathrm{Ca},{ }^{4,12,73} \mathrm{Sr},{ }^{10,76}\right.$ and $\left.\mathrm{Ba}^{11,13}\right)$. The formation energies of these dopants as substitutional defects on the $\mathrm{Bi}$ and $\mathrm{Cu}$ sites are shown in Figure S4. We find that the alkaline-earth metals preferentially substitute on the $\mathrm{Bi}$ site rather than the $\mathrm{Cu}$ site to form shallow acceptorlike defects, which is consistent with experimental observations of $p$-type doping with these group-2 elements. Preferential substitution on the $\mathrm{Cu}$ site would have resulted instead in donor-like substitutional defects and $n$-type doping.

It is well-known that $\mathrm{Mg}$ is the least effective $p$-type dopant in BiCuSeO out of the group-2 alkaline-earth metals. ${ }^{1,71,72}$ Our calculations suggest that this is due to the high formation energy of $\mathrm{Mg}_{\mathrm{Bi}}$ relative to the dominant native acceptor defect $\mathrm{V}_{\mathrm{Cu}}$ (Figure $\mathrm{S} 4)$; in other words, the solubility of $\mathrm{Mg}$ in $\mathrm{BiCuSeO}$ is low. In contrast, $\mathrm{Ca}$ and $\mathrm{Sr}$ are highly effective with predicted maximum free hole concentrations of $1.5 \times 10^{21} \mathrm{~cm}^{-3}$ and $1.9 \times 10^{21} \mathrm{~cm}^{-3}$ achieved under the most Ca- and Sr-rich doping conditions (Tables S5, S6). The predicted hole concentrations for $\mathrm{Ca}$ and $\mathrm{Sr}$ doping are also in good agreement with available experimental data (Figure 4). 4,10,12,73 For low nominal doping ( $<5$ atomic \%) with $\mathrm{Ba}$, the measured hole concentrations are $\leq 10^{20} \mathrm{~cm}^{-3}$, in agreement with our predicted range of $9.4 \times 10^{18}-1.3 \times 10^{20} \mathrm{~cm}^{-3}$. This range of hole concentrations is comparable to native and Mg-doped BiCuSeO, suggesting that $\mathrm{Ba}$ is not an effective $p$-type dopant. The trend in the predicted hole concentrations for the group-2 dopants appear reasonable if we consider the ionic radii similarity between $\mathrm{Bi}^{3+}(0.96 \AA)$ and the dopants (Mg: $0.72 \AA$, Ca: $1.00 \AA$, Sr: $1.18 \AA$, Ba: $1.35 \AA$ ). ${ }^{77}$

However, there are reports of higher hole concentrations achieved in heavily Ba-doped $\mathrm{BiCuSeO}$ with 15 atomic \% $\mathrm{Ba} .{ }^{11}$ The discrepancy between our predictions and experiments for high nominal doping concentrations could be due to the breakdown of the dilute doping assumption used in our defect calculations. In the dilute limit, it is assumed that the dopants introduce charge carriers (electrons or holes) without perturbing the electronic structure of the host material i.e., the rigid band approximation. Predictions of carrier concentrations based on the dilute doping assumption are in excellent agreement with experiments, as shown in this work for native $\mathrm{BiCuSeO}$ (Section 3.1) and in other studies on $\mathrm{Mg}_{3} \mathrm{Sb}_{2},{ }^{66} \mathrm{PbTe}^{45} \mathrm{KGaSb}_{4},{ }^{46}$ and $\mathrm{CoSb}_{3} \cdot{ }^{78}$ In Ref. 11 , it is shown that 15 at. \% Ba doping is associated with a concomitant $\sim 1 \%$ expansion in the lattice parameters, which 
(a) most $\mathrm{Cu}-/ \mathrm{Cl}-$ rich

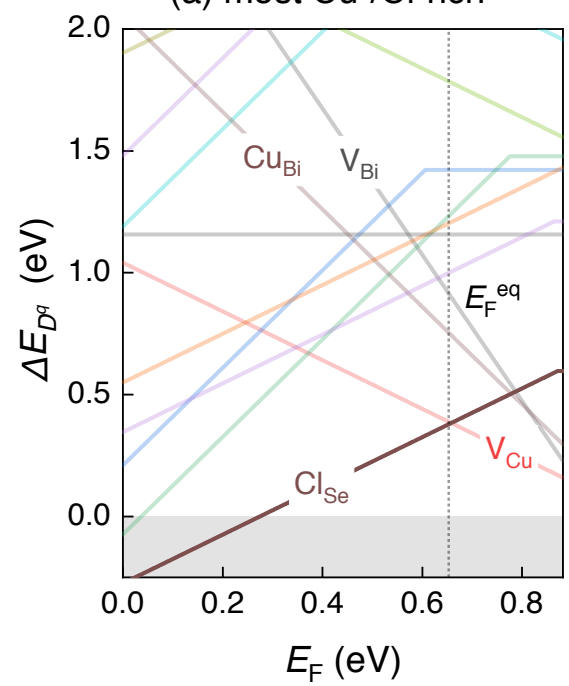

(b) most Cu-/Br-rich

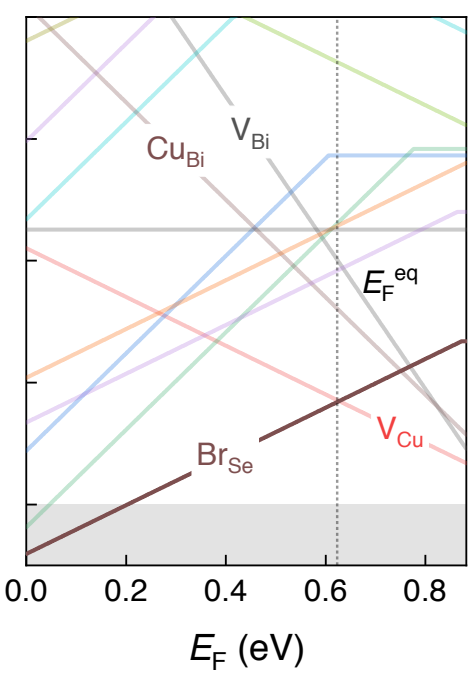

(c) most Cu-/l-rich

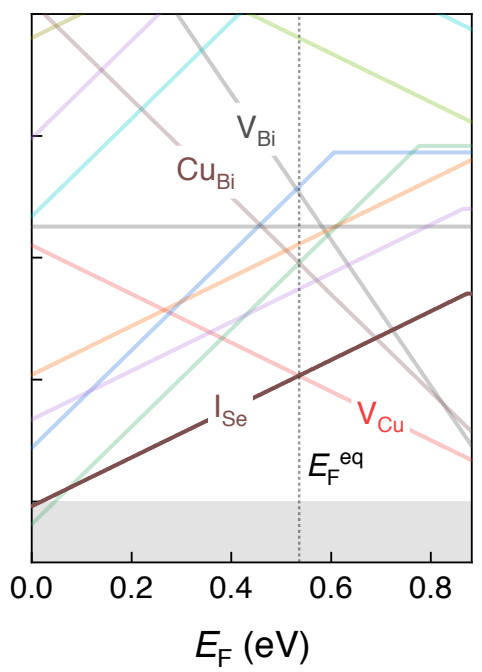

Fig. 5 Formation energy associated with (a) $\mathrm{Cl}$, (b) $\mathrm{Br}$, and (c) I doping in $\mathrm{BiCuSeO}$. For each dopant, BiCuSeO is in thermodynamic equilibrium with the following impurity phases: (a) $\mathrm{Bi}, \mathrm{Cu}_{2} \mathrm{Se}, \mathrm{BiClO}$, and $\mathrm{Bi}_{24} \mathrm{Cl}_{10} \mathrm{O}_{31}$, (b) $\mathrm{Bi}, \mathrm{Bi}_{4} \mathrm{Br}_{2} \mathrm{O}_{5}, \mathrm{Cu}_{2} \mathrm{O}$, and $\mathrm{Cu}_{2} \mathrm{Se}$, and $(\mathrm{c}) \mathrm{Bi}, \mathrm{Cu}_{2} \mathrm{Se}, \mathrm{Cu}_{2} \mathrm{O}, \mathrm{and}_{4} \mathrm{Bi}_{2} \mathrm{O}_{5}$. Halogens prefer to occupy the Se site (dopant substitutions on the $\mathrm{O}$ site are higher in energy and not shown). The native defects of BiCuSeO, from Figure 2, are shown in lighter color. The equilibrium Fermi energy $\left(E_{\mathrm{F}}^{\mathrm{eq}}\right)$ determined by charge neutrality at $973 \mathrm{~K}$ are shown as vertical dotted lines.

clearly indicates that the dilute doping assumption may no longer valid. For such high doping concentrations, interactions between the dopant atoms become prevalent, which are not considered in the dilute doping model. Nonetheless, the predicted carrier concentration ranges of the other group-2 dopants $(\mathrm{Mg}, \mathrm{Ca}, \mathrm{Sr}$ ) are in agreement with experiments, suggesting that the maximum carrier concentration attainable through group- 2 doping has been already achieved in experiments. Further increases in hole concentrations for $p$-type $\mathrm{BiCuSeO}$ is unlikely to be achieved with group-2 doping.

\subsection{2 n-type Dopants}

Our calculated native defect formation energetics reveal that $\mathrm{Bi}$ $\mathrm{CuSeO}$ is $n$-type dopable under Cu-rich growth conditions (Section 3.1). Combined with the fact that the $n$-type performance of $\mathrm{BiCuSeO}$ is predicted to surpass that of $p$-type (Section 1), it is worthwhile to search for efficient $n$-type dopants. In our search for $n$-type dopants, we assess 19 different elements, including those in group-1 (Li), group-3 (Sc, Y), group-4 (Ti, Zr, $\mathrm{Hf}$, group-12 (Zn), group-13 (Al, Ga, In, Tl) group-14 (Si, Ge, $\mathrm{Sn}, \mathrm{Pb}$ ), and group-17 (F, Cl, Br, I).

Through this broad search, we find that only group-17 halogens (Cl, Br) serve as $n$-type dopants in BiCuSeO (Figure 4). The formation energies of the substitutional halogen dopants in $\mathrm{Bi}$ $\mathrm{CuSeO}$ under the most halogen-rich thermodynamic conditions (to maximize solubility) are shown in Figure 5. The highest achievable free electron concentration by $\mathrm{Cl}$ doping is predicted to be $2.4 \times 10^{18} \mathrm{~cm}^{-3}$, when $\mathrm{BiCuSeO}$ is in equilibrium with $\mathrm{Bi}$, $\mathrm{Cu}_{2} \mathrm{Se}, \mathrm{BiClO}$, and $\mathrm{Bi}_{24} \mathrm{Cl}_{10} \mathrm{O}_{31}$ (Table S24). Similarly, $\mathrm{Br}$ is predicted to be an $n$-type dopant with highest electron concentration of $1.4 \times 10^{18} \mathrm{~cm}^{-3}$ when in equilibrium with $\mathrm{Bi}, \mathrm{Bi}_{4} \mathrm{Br}_{2} \mathrm{O}_{5}, \mathrm{Cu}_{2} \mathrm{O}$, and $\mathrm{Cu}_{2} \mathrm{Se}$ (Table S25). In contrast, we find that $\mathrm{F}$ and I are ineffective $n$-type halogen dopants (Figure 5c, Figure S5).
Zhang et al. reported $n$-type BiCuSeO by doping the material with $\mathrm{Cl}, \mathrm{Br}$, and $\mathrm{I},{ }^{30,31}$ providing valuable experimental evidence that $\mathrm{BiCuSeO}$ can indeed be doped $n$-type. Our finding that Bi$\mathrm{CuSeO}$ is $n$-type dopable (Section 3.1) is retrospectively corroborated by these experiments. The same experimental studies ${ }^{30,31}$ report that halogen doping induces an anomalous $p$ - $n$ - $p$ transition in the conductivity type with increasing temperature, which the authors attribute to weak, thermally unstable $\mathrm{Cu}-X(X=\mathrm{Cl}$, $\mathrm{Br}, \mathrm{I})$ bonds compared to the Cu-Se bond strength in the parent material. ${ }^{31}$ Based on our results, we suggest that the different thermodynamic states of the quinary Bi-Cu-Se-O- $X(X=\mathrm{Cl}, \mathrm{Br}$, I) phase space be explored in detail e.g., through phase boundary mapping ${ }^{66,79,80}$ to understand the observed $p-n-p$ transition in the conductivity type. In phase boundary mapping, the presence of specific dopant-related competing phases in a sample is the signature of the corresponding thermodynamic state defined by the elemental chemical potentials e.g., Cu-/Cl-rich. The solubility of dopants in these different thermodynamic states play a crucial role in the resulting carrier concentration, as demonstrated in several studies. ${ }^{68,81}$ Moreover, studies on the thermal stability of BiCuSeO have suggested that the material is prone to Se volatilization especially at higher temperatures, ${ }^{82,83}$ which likely affects the dopant solubility given that our results predict the substitution of the halogen atoms on the Se site. In light of our results which indicate that both $n$ - and $p$-type conductivity (Figure 3) are possible with $\mathrm{Cl}$ and $\mathrm{Br}$ depending on the thermodynamic state, we suggest that the anomalous $p-n-p$ transition be revisited with further experimental analysis.

In contrast to experiments, we predict that I is not an $n$-type dopant in BiCuSeO (Figure 4) due to its low solubility compared to $\mathrm{Cl}$ and $\mathrm{Br}$. It is curious that although our calculated carrier concentrations of $p$-type dopants (e.g., $\mathrm{Ca}, \mathrm{Sr}$ ) match experimental values rather well especially at low nominal doping concen- 
trations, I is the only dopant for which our predictions do not agree with experiments. This is especially surprising since the nominal concentration of $\mathrm{I}$ in experiments is 1 at. $\%,{ }^{31}$ which is much lower than the nominal doping concentrations of the other dopants. Due to the limited number of halogen doping studies, it is difficult to gauge the exact cause of the disagreement. As mentioned before, the apparent $p-n-p$ transition in the conductivity type with temperature ${ }^{30,31}$ suggests some anomalous behavior of the material. Further experimental studies of halogen doping in conjunction with first-principles defect and dopant calculations are needed to resolve these issues.

Apart from the halogens, we find that none of the other considered $n$-type dopants are effective. While Li and $\mathrm{Zn}$ are known $p$ type dopants in $\mathrm{BiCuSeO},{ }^{28,74,84}$ we wanted to explore the possibility of $n$-type doping if donor defects, $\mathrm{Li}_{\mathrm{i}}$ and $\mathrm{Zn}_{\mathrm{Cu}}$, are favorable under certain thermodynamic equilibrium conditions. However, our results suggest that this is not the case for $\mathrm{Li}$ and $\mathrm{Zn}$ doping. For example, Li preferentially substitutes on the $\mathrm{Bi}$ site $\left(\mathrm{Li}_{\mathrm{Bi}}\right)$ to form an acceptor defect that leads to $p$-type rather than the desired $n$-type doping (Figure S6). As expected, Li isovalently substitutes the $\mathrm{Cu}$ site forming the neutral $\mathrm{Li}_{\mathrm{Cu}}$ defect. Our predicted range of carrier concentrations for $\mathrm{Li}$-doped $\mathrm{BiCuSeO}$ matches the experimentally-measured hole concentrations ${ }^{74}$ (Figure 4), suggesting that the formation of $\mathrm{Li}_{\mathrm{i}}$ is not favorable. For $\mathrm{Zn}$, we predict that the substitution on the $\mathrm{Cu}$ site ( $\mathrm{Zn}_{\mathrm{Cu}}$ in Figure S7) is associated with a high formation energy such that the $\mathrm{BiCuSeO}$ is still $p$-type with free hole concentration of $3.3 \times 10^{18} \mathrm{~cm}^{-3}$ (Table s9).

Group-3 (Sc, Y) and group-13 (Al, Ga, and In) elements are found to be isovalent dopants preferentially substituting on the Bi site (Figures S8, S10). Substitution on the Cu site, which creates donor defects, is associated with high formation energies. It is interesting that $\mathrm{Tl}$, which is also a group-13 element, acts as an acceptor on the Bi site instead of an isovalent dopant (Figure S10d). However, the high formation energies i.e., low solubility of group-3 and group-13 dopants in $\mathrm{BiCuSeO}$ make them ineffective $n$-type dopants (Figure 4). We also find that group-4 dopants (Ti, Zr, Hf) are also ineffective due to their low solubility even under the most dopant-rich and Cu-rich conditions (Figure S9). Therefore, these dopants do not extend the range of achievable carrier concentration from what is already attained through native self-doping (Figure 4).

We also consider $n$-type doping of $\mathrm{BiCuSeO}$ with group-14 elements ( $\mathrm{Si}, \mathrm{Ge}, \mathrm{Sn}, \mathrm{Pb}$ ). It is worth mentioning that a previous computational study of group-14 dopants by Shen et al. suggested that $\mathrm{Si}$ is an exceptional $n$-type dopant for BiCuSeO. ${ }^{85}$ While our results agree that $\mathrm{Si}_{\mathrm{Bi}}$ is a donor defect and $\mathrm{Ge}_{\mathrm{Bi}}, \mathrm{Sn}_{\mathrm{Bi}}$, and $\mathrm{Pb}_{\mathrm{Bi}}$ are acceptors (Figure $\mathrm{S} 11$ ), the formation energies of group-14 dopants in $\mathrm{BiCuSeO}$ are too high to increase the free electron concentration. We believe that this discrepancy is attributed to the phase stability information included in our calculation of the defect formation energy. While Shen et al. assume that group-14 doped $\mathrm{BiCuSeO}$ is in thermodynamic equilibrium with the dopant in its elemental form i.e., $\Delta \mu_{\text {dopant }}=0 \mathrm{eV}$, our phase stability analysis, which considers all possible competing phases (Tables S14 - S17), shows that this is not possible. For all group-14 dopants, the most dopant-rich condition corresponds to $\Delta \mu_{\text {dopant }}<0 \mathrm{eV}$. For example, we find Si-doped $\mathrm{BiCuSeO}$ is in equilibrium with elemental $\mathrm{Bi}, \mathrm{Cu}_{3} \mathrm{Se}_{2}, \mathrm{Bi}_{2} \mathrm{Se}_{3}$, and $\mathrm{SiO}_{2}$ in the most Si-rich phase region (Table S14). As a result, our calculated formation energies of the group-14 dopants in $\mathrm{BiCuSeO}$ are higher than those calculated by Shen et al., ${ }^{85}$ suggesting that the solubility of group-14 dopants is much lower than previously predicted.

\section{Conclusions and Outlook}

We use first-principles defect calculations to show that the low formation energy of copper vacancies is responsible for the native p-type character of $\mathrm{BiCuSeO}$. Interestingly, we find that $\mathrm{BiCuSeO}$ is also $n$-type dopable under Cu-rich growth conditions. Through a broad computational survey of plausible $n$-type dopants, we identify $\mathrm{Cl}$ and $\mathrm{Br}$ as the most effective $n$-type dopants. We find that more than half of the plausible dopants are ineffective, providing useful guidance for future experimental doping efforts; for $n$-type doping, experiments should continue to focus on halogen doping to resolve the anomalous temperature-dependent $p-n-p$ transition.

BiCuSeO is a well-known $p$-type TE material. The prospects of $n$-type doping, as revealed by our defect calculations and recent experimental doping studies, prompt us to ask whether the electron concentration in $\mathrm{BiCuSeO}$ can be optimized to unlock the high $n$-type TE performance predicted by computations. Furthermore, it is also worth asking whether we can design chemical analogues of $\mathrm{BiCuSeO}$, with similar thermopower and thermal conductivity, that can be doped both $p$ - and $n$-type.

We may envision such a design possibility by comparing the defect energetics of $\mathrm{BiCuSeO}$ with one of its chemical analogues, LaCuSeO, which crystallizes in the same $P 4 / \mathrm{nmm}$ layered structure. While the formation energy of the acceptor $\mathrm{V}_{\mathrm{Cu}}$ is relatively low in both compounds, which is expected due to the common $\left(\mathrm{Cu}_{2} \mathrm{Se}_{2}\right)^{2-}$ layers in both structures, there is little opportunity for $n$-type doping of LaCuSeO. ${ }^{86}$ The distinctly different $n$-type dopability of $\mathrm{BiCuSeO}$ and $\mathrm{LaCuSeO}$ can be explained by the relative positions of the conduction band edge (CBE). Heuristic guidelines suggest that compounds with lower CBEs tend to be $n$-type dopable. ${ }^{87,88}$ Since the $\mathrm{CBE}$ of $\mathrm{BiCuSeO}$, which is primarily derived from $\mathrm{Bi}-6 p$ states, is lower than that of $\mathrm{LaCuSeO}$, where the CBE is composed of Cu- $4 s / \mathrm{La}-5 d$ states, ${ }^{49}$ it is expected that La$\mathrm{CuSeO}$ would be less $n$-type dopable compared to BiCuSeO. This heuristic comparison between $\mathrm{LaCuSeO}$ and $\mathrm{BiCuSeO}$ contextualizes chemical substitution as an inverse design principle to realize $p$ - and $n$-type dopable materials. ${ }^{48,89}$ By substituting Bi with an element with larger electron affinity e.g., Sb, that lowers the energy of the CBE, an $n$-type dopable analogue of $\mathrm{BiCuSeO}$ may be possible. The discovery and design of such chemical analogues will be the focus of a future study.

\section{Acknowledgements}

MYT is funded by the United States Department of Energy through the Computational Science Graduate Fellowship (DOE CSGF) under grant number DE-SC0020347. JQ is funded by the NSF DIGI-MAT program, grant number 1922758. GJS acknowledges support from NSF DMR, DMREF grant number 
1729487 and P.G. acknowledges support from NSF through award DMR-2102409. The research was performed using computational resources sponsored by the Department of Energy's Office of Energy Efficiency and Renewable Energy and located at the NREL. This research was also supported in part through the computational resources and staff contributions provided for the Quest high performance computing facility at Northwestern University, which is jointly supported by the Office of the Provost, the Office for Research, and Northwestern University Information Technology.

\section{References}

1 L.-D. Zhao, J. He, D. Berardan, Y. Lin, J.-F. Li, C.-W. Nan and N. Dragoe, Energy Environ. Sci., 2014, 7, 2900.

2 Y. Liu, L.-D. Zhao, Y. Zhu, Y. Liu, F. Li, M. Yu, D.-B. Liu, W. Xu, Y.-H. Lin and C.-W. Nan, Adv. Energy Mater., 2016, 6, 1502423.

3 F. Li, J.-F. Li, L.-D. Zhao, K. Xiang, Y. Liu, B.-P. Zhang, Y.-H. Lin, C.-W. Nan and H.-M. Zhu, Energy Environ. Sci., 2012, 5, 7188.

4 Y.-L. Pei, J. He, J.-F. Li, F. Li, Q. Liu, W. Pan, C. Barreteau, D. Berardan, N. Dragoe and L.-D. Zhao, NPG Asia Mater., 2013, 5, e47.

5 H. Shao, X. Tan, G.-Q. Liu, J. Jiang and H. Jiang, Sci. Rep., 2016, 6, 1.

6 X. Zhang, C. Chang, Y. Zhou and L.-D. Zhao, Materials, 2017, 10, 198.

7 R. Liu, X. Tan, Y.-C. Liu, G.-K. Ren, J.-L. Lan, Z.-F. Zhou, C.-W. Nan and Y.-H. Lin, Rare Metals, 2018, 37, 259.

8 G.-K. Ren, J.-L. Lan, L.-D. Zhao, C. Liu, H. Yuan, Y. Shi, Z. Zhou and Y.-H. Lin, Mater. Today, 2019, 29, 68.

9 G. J. Snyder and E. S. Toberer, Nat. Mater., 2008, 7, 105.

10 C. Barreteau, D. Berardan, E. Amzallag, L. Zhao and N. Dragoe, Chem. Mater., 2012, 24, 3168.

11 J. Li, J. Sui, Y. Pei, C. Barreteau, D. Berardan, N. Dragoe, W. Cai, J. He and L.-D. Zhao, Energy Environ. Sci., 2012, 5, 8543.

12 F. Li, T.-R. Wei, F. Kang and J.-F. Li, J. Mater. Chem. A, 2013, $1,11942$.

13 J. Sui, J. Li, J. He, Y.-L. Pei, D. Berardan, H. Wu, N. Dragoe, W. Cai and L.-D. Zhao, Energy Environ. Sci., 2013, 6, 2916.

14 J. Li, J. Sui, Y. Pei, X. Meng, D. Berardan, N. Dragoe, W. Cai and L.-D. Zhao, J. Mater. Chem. A, 2014, 2, 4903.

15 M. Zhang, J. Yang, Q. Jiang, L. Fu, Y. Xiao, Y. Luo, D. Zhang, Y. Cheng and Z. Zhou, J. Electron. Mater., 2015, 44, 2849.

16 J.-L. Lan, C. Deng, W. Ma, G.-K. Ren, Y.-H. Lin and X. Yang, J. Alloy Compd., 2017, 708, 955.

17 D. Sun Lee, T.-H. An, M. Jeong, H.-S. Choi, Y. Soo Lim, W.S. Seo, C.-H. Park, C. Park and H.-H. Park, Appl. Phys. Lett., 2013, 103, 232110.

18 J.-L. Lan, W. Ma, C. Deng, G.-K. Ren, Y.-H. Lin and X. Yang, J. Mater. Sci., 2017, 52, 11569.

19 A. Achour, K. Chen, M. J. Reece and Z. Huang, J. Alloy Compd.,
2018, 735, 861.

20 Y. Liu, J. Ding, B. Xu, J. Lan, Y. Zheng, B. Zhan, B. Zhang, Y. Lin and C. Nan, Appl. Phys. Lett., 2015, 106, 233903.

21 S. Tan, H. Lei, D. Shao, H. Lv, W. Lu, Y. Huang, Y. Liu, B. Yuan, L. Zu, X. Kan, W. Song and Y. Sun, Appl. Phys. Lett., 2014, 105, 082109.

22 Y.-C. Liu, Y.-H. Zheng, B. Zhan, K. Chen, S. Butt, B. Zhang and Y.-H. Lin, J. Eur. Ceram. Soc., 2015, 35, 845.

23 M. U. Farooq, S. Butt, K. Gao, X. L. Pang, X. Sun, Asfandiyar, F. Mohmed, A. Ahmad, A. Mahmood and N. Mahmood, J. Alloy. Compd., 2017, 691, 572.

24 J. Yan, P. Gorai, B. Ortiz, S. Miller, S. A. Barnett, T. Mason, V. Stevanović and E. S. Toberer, Energy Environ. Sci., 2015, 8, 983.

25 S. A. Miller, P. Gorai, B. R. Ortiz, A. Goyal, D. Gao, S. A. Barnett, T. O. Mason, G. J. Snyder, Q. Lv, V. Stevanović and E. S. Toberer, Chem. Mater., 2017, 29, 2494.

26 J. Yang, G. Yang, G. Zhang and Y. X. Wang, J. Mater. Chem. A, 2014, 2, 13923.

27 R. McKinney, P. Gorai, E. S. Toberer and V. Stevanovic, Chem. Mater., 2019, 31, 2048.

28 G.-K. Ren, S. Butt, Y.-C. Liu, J.-L. Lan, Y.-H. Lin, C.-W. Nan, F. Fu and X.-F. Tang, Phys. Status Solidi A, 2014, 211, 2616.

29 Z. Zhou, X. Tan, G. Ren, Y. Lin and C. Nan, J. Electron Mater., 2017, 46, 2593.

30 X. Zhang, D. Feng, J. He and L.-D. Zhao, J. Solid State Chem., 2018, 258, 510.

31 X. Zhang, D. Wang, G. Wang and L.-D. Zhao, Ceram. Int., 2019, 45, 14953.

32 S. Tan, C. Gao, C. Wang, Y. Sun, Q. Jing, Q. Meng, T. Zhou and J. Ren, Solid State Sci., 2019, 98, 106019.

33 G. Kresse and J. Furthmüller, Comp. Mater. Sci., 1996, 6, 15.

34 G. Kresse and J. Furthmüller, Phys. Rev. B, 1996, 54, 11169.

35 P. E. Blöchl, Phys. Rev. B, 1994, 50, 17953.

36 G. Kresse and D. Joubert, Phys. Rev. B, 1999, 59, 1758.

37 S. Dudarev, G. Botton, S. Savrasov, C. Humphreys and A. Sutton, Phys. Rev. B, 1998, 57, 1505.

38 P. Gorai, E. S. Toberer and V. Stevanović, Phys. Chem. Chem. Phys., 2016, 18, 31777.

39 J. P. Perdew, K. Burke and M. Ernzerhof, Phys. Rev. Lett., 1996, 77, 3865.

40 P. Gorai, E. S. Toberer and V. Stevanović, J. Mater. Chem. A, 2016, 4, 11110.

41 J. Klimeš, D. R. Bowler and A. Michaelides, Phys. Rev. B, 2011, 83, 195131.

42 N. Marom, A. Tkatchenko, M. Scheffler and L. Kronik, J. Chem. Theory Comput., 2010, 6, 81.

43 P. E. Blöchl, O. Jepsen and O. K. Andersen, Phys. Rev. B, 1994, 49, 16223.

44 H. Peng, D. O. Scanlon, V. Stevanovic, J. Vidal, G. W. Watson and S. Lany, Phys. Rev. B, 2013, 88, 115201.

45 A. Goyal, P. Gorai, E. S. Toberer and V. Stevanović, npj Comput. Mater., 2017, 3, 1. 
46 B. R. Ortiz, P. Gorai, V. Stevanovic and E. S. Toberer, Chem. Mater., 2017, 29, 4523.

47 P. Gorai, B. R. Ortiz, E. S. Toberer and V. Stevanović, J. Mater. Chem. A, 2018, 6, 13806.

48 P. Gorai, A. Ganose, A. Faghaninia, A. Jain and V. Stevanović, Mater. Horiz., 2020, 7, 1809.

49 H. Hiramatsu, H. Yanagi, T. Kamiya, K. Ueda, M. Hirano and H. Hosono, Chem. Mater., 2008, 20, 326.

50 W. Setyawan and S. Curtarolo, Comp. Mater. Sci., 2010, 49, 299.

51 S. Curtarolo, W. Setyawan, G. L. Hart, M. Jahnatek, R. V. Chepulskii, R. H. Taylor, S. Wang, J. Xue, K. Yang, O. Levy, M. J. Mehl, H. T. Stokes, D. O. Demchenko and D. Morgan, Comp. Mater. Sci., 2012, 58, 218.

52 S. Lany and A. Zunger, Model. Simul. Mater. Sc., 2009, 17, 084002.

53 C. Freysoldt, B. Grabowski, T. Hickel, J. Neugebauer, G. Kresse, A. Janotti and C. G. Van de Walle, Rev. Mod. Phys., 2014, 86, 253.

54 S. Lany, Phys. Rev. B, 2008, 78, 245207.

55 V. Stevanović, S. Lany, X. Zhang and A. Zunger, Phys. Rev. B, 2012, 85, 115104.

56 D. D. Wagman, W. H. Evans, V. B. Parker, R. H. Schumm and I. Halow, 1982.

57 D. R. Lide, CRC Handbook of Chemistry and Physics, 1992.

58 A. Olin, 2005.

59 H. Oppermann, H. Göbel, P. Schmidt, H. Schadow and V. Vassilev, Z. Naturforsch. B, 1999, 54, 261.

60 G. Moiseev, N. Vatolin and N. Belousova, J. Therm. Anal. Calorim., 2000, 61, 289.

61 N. Babanly, Y. A. Yusibov, Z. Aliev and M. Babanly, Russ. J. Inorg. Chem., 2010, 55, 1471.

62 S. Lany and A. Zunger, Phys. Rev. B, 2008, 78, 235104.

63 E. Burstein, Phys. Rev., 1954, 93, 632.

64 A. Goyal, P. Gorai, H. Peng, S. Lany and V. Stevanović, Comp. Mater. Sci., 2017, 130, 1.

65 https://github.com/prashungorai/papers/tree/ main/2021/BiCuseo.

66 S. Ohno, K. Imasato, S. Anand, H. Tamaki, S. D. Kang, P. Gorai, H. K. Sato, E. S. Toberer, T. Kanno and G. J. Snyder, Joule, 2018, 2, 141.

67 H. J. Monkhorst and J. D. Pack, Phys. Rev. B, 1976, 13, 5188.

68 M. Wood, M. Y. Toriyama, S. Dugar, J. Male, S. Anand,
V. Stevanović and G. J. Snyder, Adv. Energy Mater., 2021, 11, 2100181.

69 Y. Liu, L.-D. Zhao, Y. Liu, J. Lan, W. Xu, F. Li, B.-P. Zhang, D. Berardan, N. Dragoe, Y.-H. Lin, C.-W. Nan, J.-F. Li and H. Zhu, J. Am. Chem. Soc., 2011, 133, 20112.

70 G.-K. Ren, S. Wang, Z. Zhou, X. Li, J. Yang, W. Zhang, Y.-H. Lin, J. Yang and C.-W. Nan, Nat. Comm., 2019, 10, 1.

71 J.-L. Lan, B. Zhan, Y.-C. Liu, B. Zheng, Y. Liu, Y.-H. Lin and C.-W. Nan, Appl. Phys. Lett., 2013, 102, 123905.

72 J. Li, J. Sui, C. Barreteau, D. Berardan, N. Dragoe, W. Cai, Y. Pei and L.-D. Zhao, J. Alloy Compd., 2013, 551, 649.

73 C.-L. Hsiao and X. Qi, Acta Mater., 2016, 102, 88.

74 J. Tang, R. Xu, J. Zhang, D. Li, W. Zhou, X. Li, Z. Wang, F. Xu, G. Tang and G. Chen, ACS Appl. Mater. Int., 2019, 11, 15543.

75 J.-L. Lan, Y.-C. Liu, B. Zhan, Y.-H. Lin, B. Zhang, X. Yuan, W. Zhang, W. Xu and C.-W. Nan, Adv. Mater., 2013, 25, 5086.

76 L.-D. Zhao, D. Berardan, Y.-L. Pei, C. Byl, L. Pinsard-Gaudart and N. Dragoe, Appl. Phys. Lett., 2010, 97, 092118.

77 R. D. Shannon, Acta Crystall. A-Crys., 1976, 32, 751.

78 G. Li, U. Aydemir, M. Wood, W. A. Goddard III, P. Zhai, Q. Zhang and G. J. Snyder, Chem. Mater., 2017, 29, 3999.

79 C. M. Crawford, B. R. Ortiz, P. Gorai, V. Stevanovic and E. S. Toberer, J. Mater. Chem. A, 2018, 6, 24175.

80 P. Jood, J. P. Male, S. Anand, Y. Matsushita, Y. Takagiwa, M. G. Kanatzidis, G. J. Snyder and M. Ohta, J. Am. Chem. Soc., 2020, 142, 15464.

81 R. Orenstein, J. P. Male, M. Toriyama, S. Anand and G. J. Snyder, J. Mater. Chem. A, 2021, 9, 7208.

82 F. Li, T.-R. Wei, F. Kang and J.-F. Li, J. Alloy Compd., 2014, 614, 394.

83 A. Novitskii, G. Guélou, A. Voronin, T. Mori and V. Khovaylo, Scripta Mater., 2020, 187, 317.

84 G. Ren, S. Butt, C. Zeng, Y. Liu, B. Zhan, J. Lan, Y. Lin and C. Nan, J. Electron. Mater., 2015, 44, 1627.

85 J. Shen and Y. Chen, ACS Appl. Mater. Inter., 2017, 9, 27372.

86 D. O. Scanlon, J. Buckeridge, C. R. A. Catlow and G. W. Watson, J. Mater. Chem. C, 2014, 2, 3429.

87 S. Zhang, S.-H. Wei and A. Zunger, J. Appl. Phys., 1998, 83, 3192.

88 S.-H. Wei, Comp. Mater. Sci., 2004, 30, 337.

89 J. Qu, V. Stevanović, E. Ertekin and P. Gorai, J. Mater. Chem. A, 2020, 8, 25306. 


\title{
- Supplementary Information -
}

\section{Defect Chemistry and Doping of BiCuSeO}

\author{
Michael Y. Toriyama, ${ }^{*, \dagger}$ Jiaxing $Q u{ }^{\ddagger}$ G. Jeffrey Snyder, ${ }^{\dagger}$ and Prashun Gorai*, ${ }^{*}$ \\ $\dagger$ †aterials Science and Engineering, Northwestern University, Evanston, IL 60208, USA. \\ $\ddagger$ Mechanical Engineering, University of Illinois at Urbana-Champaign, Urbana, IL 61801. \\ \Metallurgical and Materials Engineeering, Colorado School of Mines, Golden, CO 80401, USA. \\ E-mail: MichaelToriyama2024@u.northwestern.edu; pgorai@mines.edu
}




\section{Pristine and Interstitial Structures}

(a) BiCuSeO

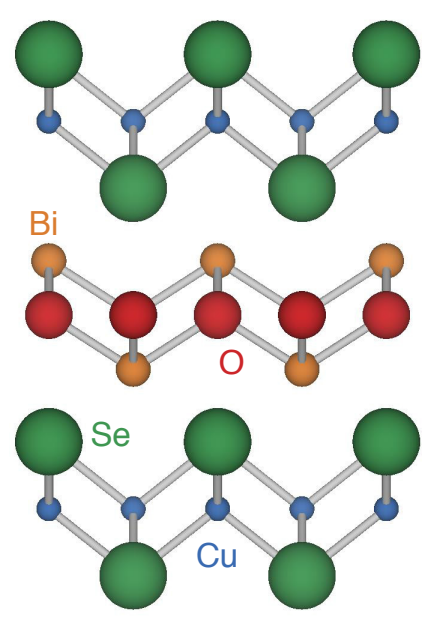

(b) Cu interstitial
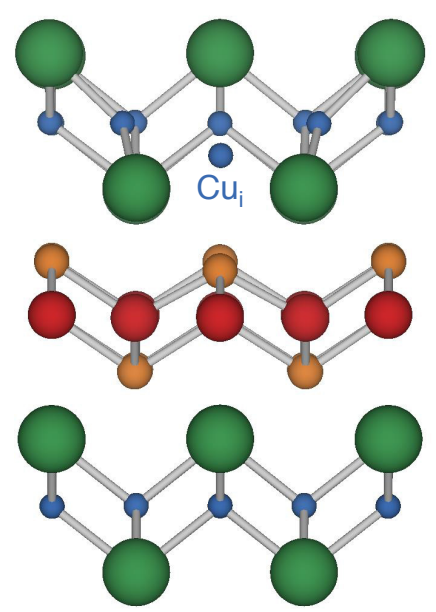

(c) $O$ interstitial

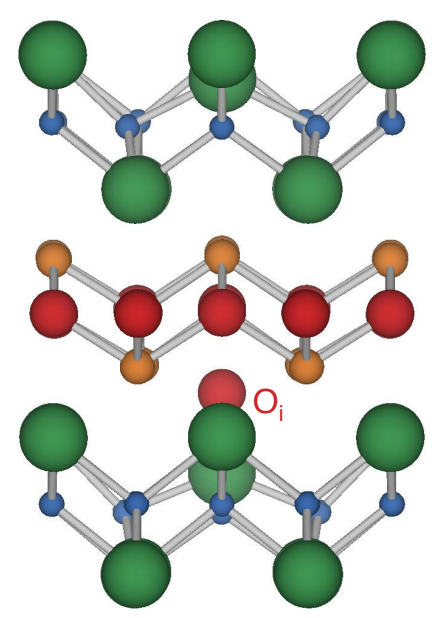

Figure S1: (a) Crystal structure of $\mathrm{BiCuSeO}$, (b) Structure of copper interstitial $\left(\mathrm{Cu}_{\mathrm{i}}^{+1}\right)$, and (c) Structure of oxygen interstitial $\left(\mathrm{O}_{\mathrm{i}}^{0}\right)$.

\section{Calculated Lattice Parameters}

\begin{tabular}{lcccc}
\hline Method & $a(\AA)$ & $c(\AA)$ & $a$ Error $(\%)$ & $c$ Error $(\%)$ \\
\hline PBE $+U$ & 3.949 & 9.062 & 0.52 & 1.49 \\
vdW $+U$ & 3.926 & 8.927 & 0.08 & 0.02 \\
Experiment $^{1}$ & 3.929 & 8.929 & & \\
\hline
\end{tabular}

Table S1: Lattice constants calculated using different functionals and compared to experimental values. ${ }^{1}$ The experimental lattice constants are better reproduced with the van der Waals-corrected functional with Hubbard $U$ correction $(\mathrm{vdW}+U)$. 


\section{Electronic Structure of BiCuSeO}

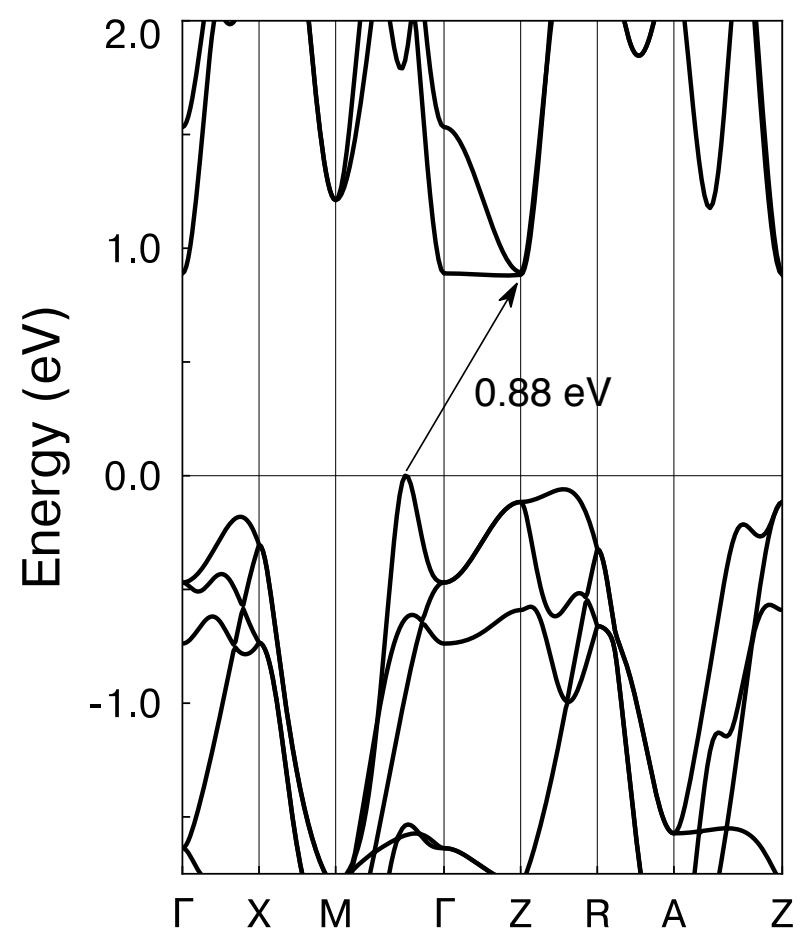

Figure S2: Computed electronic band structure of $\mathrm{BiCuSeO}$ along the special $k$-point paths of the Brillouin zone. The band edge positions are rigidly shifted to according to GW and spin-orbit coupling calculations. 


\section{Elemental Reference Chemical Potentials}

\begin{tabular}{|c|c|}
\hline Element & $\mu^{0}(\mathrm{eV})$ \\
\hline $\mathrm{Bi}$ & -4.42 \\
\hline $\mathrm{Cu}$ & -1.65 \\
\hline $\mathrm{Se}$ & -3.63 \\
\hline $\mathrm{O}$ & -4.76 \\
\hline $\mathrm{Li}$ & -1.64 \\
\hline $\mathrm{Zn}$ & -0.80 \\
\hline $\mathrm{Mg}$ & -1.00 \\
\hline $\mathrm{Ca}$ & -1.60 \\
\hline $\mathrm{Sr}$ & -1.15 \\
\hline $\mathrm{Ba}$ & -1.34 \\
\hline $\mathrm{Al}$ & -2.81 \\
\hline $\mathrm{Ga}$ & -2.30 \\
\hline In & -2.27 \\
\hline $\mathrm{Tl}$ & -2.35 \\
\hline $\mathrm{Si}$ & -4.74 \\
\hline $\mathrm{Ge}$ & -4.07 \\
\hline Sn & -3.65 \\
\hline $\mathrm{Pb}$ & -3.79 \\
\hline $\mathrm{Sc}$ & -4.49 \\
\hline $\mathrm{Y}$ & -4.81 \\
\hline $\mathrm{Ti}$ & -5.39 \\
\hline $\mathrm{Zr}$ & -5.97 \\
\hline $\mathrm{Hf}$ & -7.51 \\
\hline $\mathrm{F}$ & -1.52 \\
\hline $\mathrm{Cl}$ & -1.73 \\
\hline $\mathrm{Br}$ & -1.74 \\
\hline I & -1.67 \\
\hline
\end{tabular}

Table S2: Elemental reference chemical potentials $\mu^{0}$, fitted to experimental formation enthalpies. ${ }^{2,3}$ $\mathrm{GGA}+\mathrm{U}$ functional is used to calculate the total energy of the compounds used in the fitting. 


\section{Phase Equilibria of BiCuSeO}

\begin{tabular}{|c|c|c|c|c|c|}
\hline Equilibrium Phases & $\Delta \mu_{\mathrm{Bi}}$ & $\Delta \mu_{\mathrm{Cu}}$ & $\Delta \mu_{\mathrm{O}}$ & $\Delta \mu_{\mathrm{Se}}$ & $p-n\left(\mathrm{~cm}^{-3}\right)$ \\
\hline $\mathrm{Se}, \mathrm{Cu}_{3} \mathrm{Se}_{2}, \mathrm{Bi}_{2} \mathrm{Se}_{3}$ & -0.378 & -0.62 & -1.923 & 0.0 & $7.36 \times 10^{19}$ \\
\hline $\mathrm{Se}, \mathrm{Bi}_{2} \mathrm{O}_{2} \mathrm{Se}, \mathrm{Bi}_{2} \mathrm{O}_{3}$ & -0.602 & -0.708 & -1.61 & 0.0 & $1.26 \times 10^{20}$ \\
\hline $\mathrm{Se}, \mathrm{Bi}_{2} \mathrm{O}_{2} \mathrm{Se}, \mathrm{Bi}_{2} \mathrm{Se}_{3}$ & -0.378 & -0.708 & -1.835 & 0.0 & $1.25 \times 10^{20}$ \\
\hline $\mathrm{Se}, \mathrm{Cu}_{3} \mathrm{Se}_{2}, \mathrm{Bi}_{2} \mathrm{O}_{3}$ & -0.865 & -0.62 & -1.435 & 0.0 & $7.48 \times 10^{19}$ \\
\hline $\mathrm{Cu}_{2} \mathrm{O}, \mathrm{Cu}_{3} \mathrm{Se}_{2}, \mathrm{Bi}_{2} \mathrm{O}_{3}$ & -0.603 & -0.445 & -1.61 & -0.262 & $2.6 \times 10^{19}$ \\
\hline $\mathrm{Cu}_{2} \mathrm{Se}, \mathrm{Cu}_{2} \mathrm{O}, \mathrm{Cu}_{3} \mathrm{Se}_{2}$ & -0.285 & -0.318 & -1.864 & -0.453 & $1.13 \times 10^{19}$ \\
\hline $\mathrm{Bi}, \mathrm{Cu}_{2} \mathrm{O}, \mathrm{Bi}_{2} \mathrm{O}_{3}$ & 0.0 & -0.244 & -2.012 & -0.664 & $5.61 \times 10^{18}$ \\
\hline $\mathrm{Bi}, \mathrm{Cu}_{2} \mathrm{Se}, \mathrm{Cu}_{2} \mathrm{O}$ & 0.0 & -0.223 & -2.054 & -0.643 & $5.11 \times 10^{18}$ \\
\hline $\mathrm{Bi}, \mathrm{Cu}_{2} \mathrm{Se}, \mathrm{Cu}_{3} \mathrm{Se}_{2}$ & 0.0 & -0.318 & -2.149 & -0.453 & $1.1 \times 10^{19}$ \\
\hline $\mathrm{Bi}, \mathrm{Cu}_{3} \mathrm{Se}_{2}, \mathrm{Bi}_{2} \mathrm{Se}_{3}$ & 0.0 & -0.452 & -2.216 & -0.252 & $2.33 \times 10^{19}$ \\
\hline $\mathrm{Bi}, \mathrm{Bi}_{2} \mathrm{O}_{2} \mathrm{Se}, \mathrm{Bi}_{2} \mathrm{O}_{3}$ & 0.0 & -0.507 & -2.012 & -0.402 & $3.44 \times 10^{19}$ \\
\hline $\mathrm{Bi}, \mathrm{Bi}_{2} \mathrm{O}_{2} \mathrm{Se}, \mathrm{Bi}_{2} \mathrm{Se}_{3}$ & 0.0 & -0.582 & -2.087 & -0.252 & $5.4 \times 10^{19}$ \\
\hline
\end{tabular}

Table S3: Chemical potentials $\Delta \mu_{\mathrm{i}}$ (in eV) in all phase regions of the quaternary Bi-Cu-Se-O phase space that are in equilibrium with $\mathrm{BiCuSeO}$. The corresponding charge carrier concentration in each phase region, as determined by charge neutrality at the typical synthesis temperature of $973 \mathrm{~K}$, is listed. 
Native Defects in BiCuSeO

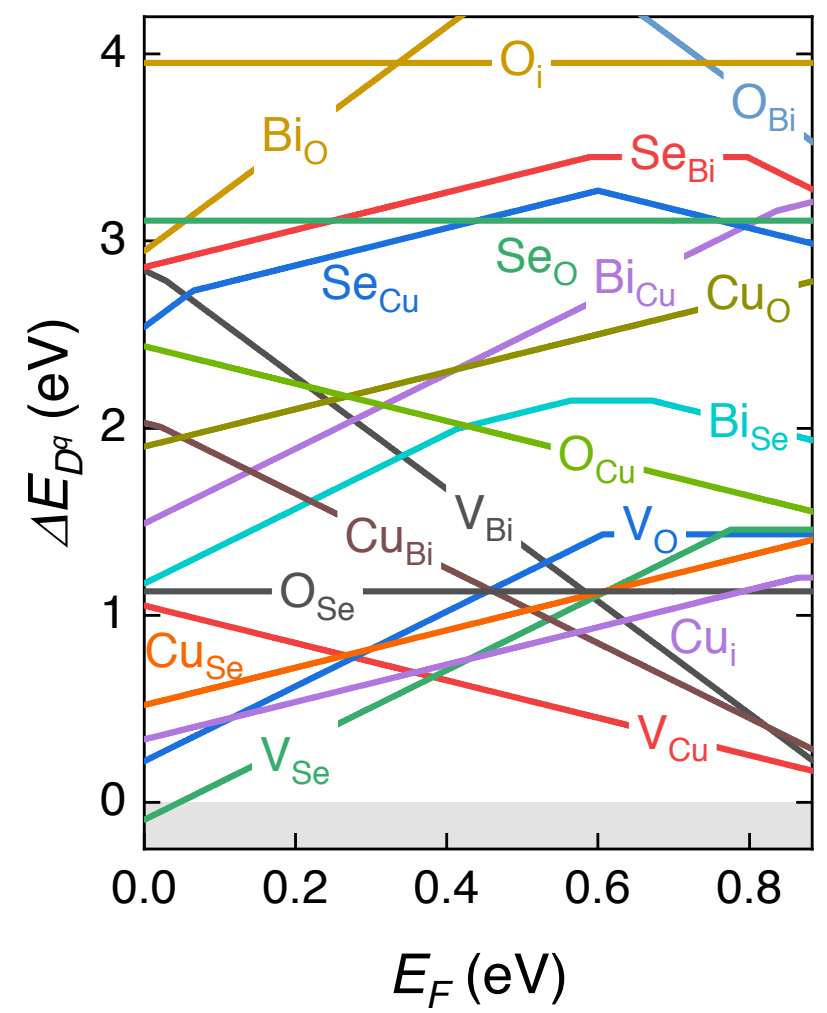

Figure S3: Formation energy $\left(\Delta E_{D^{q}}\right)$ as a function of Fermi energy $\left(E_{\mathrm{F}}\right)$ of all native defects in BiCuSeO under the most $\mathrm{Cu}$-rich condition where $\mathrm{BiCuSeO}$ is in equilibrium with $\mathrm{Bi}, \mathrm{Cu}_{2} \mathrm{Se}$, and $\mathrm{Cu}_{2} \mathrm{O}$. 


\section{Group-2 Doping: $\mathrm{Mg}, \mathrm{Ca}, \mathrm{Sr}, \mathrm{Ba}$}

(a) most Cu-poor/Mg-rich

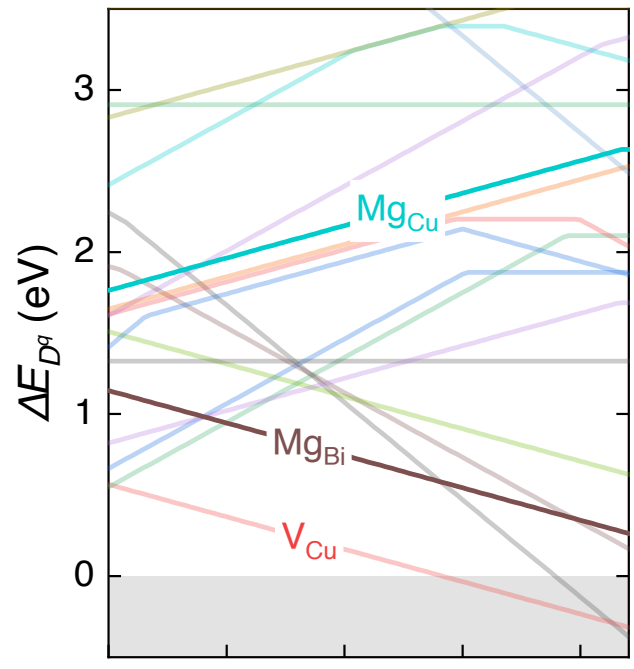

(c) most Cu-poor/Sr-rich

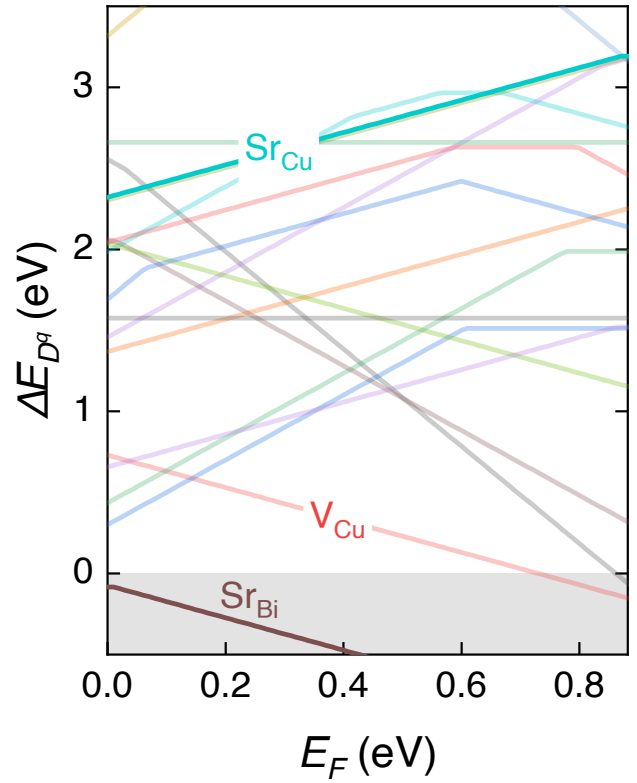

(b) most Cu-poor/Ca-rich

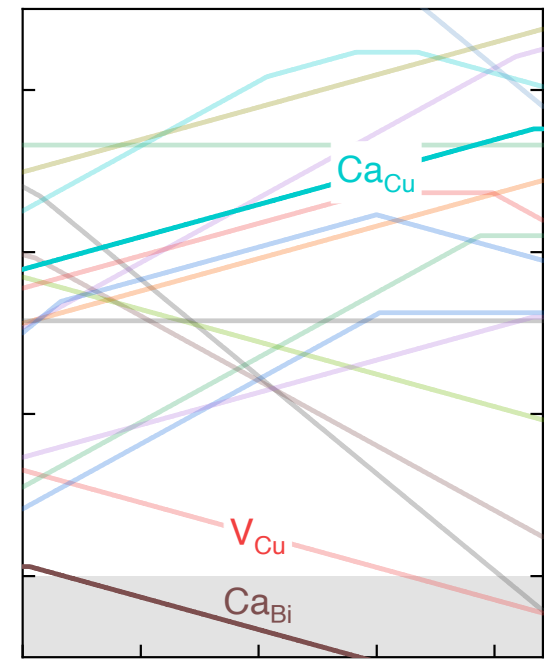

(d) most Cu-poor/Ba-rich

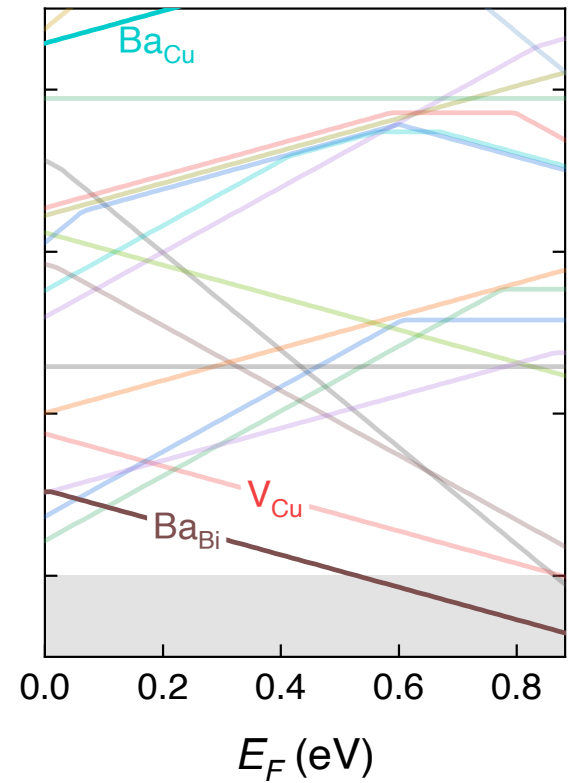

Figure S4: Formation energy of defects associated with (a) Mg, (b) Ca, (c) Sr, and (d) Ba doping under the most $\mathrm{Cu}$-poor and dopant-rich conditions i.e., phase regions that yield the highest hole concentrations. $\mathrm{BiCuSeO}$ is in equilibrium with the following phases: (a) Se, $\mathrm{MgO}, \mathrm{Bi}_{2} \mathrm{O}_{2} \mathrm{Se}$, and $\mathrm{Bi}_{2} \mathrm{O}_{3}$, (b) Se, $\mathrm{CaO}$, $\mathrm{Cu}_{3} \mathrm{Se}_{2}$, and $\mathrm{CaSeO}_{3}$, (c) $\mathrm{SrSeO}_{3}, \mathrm{SrSe}, \mathrm{Bi}_{2} \mathrm{O}_{5} \mathrm{Sr}_{2}$, and $\mathrm{Cu}_{3} \mathrm{Se}_{2}$, and (d) $\mathrm{BaCu}_{2} \mathrm{Se}_{2}, \mathrm{BaSeO}_{3}, \mathrm{Cu}_{3} \mathrm{Se}_{2}$, and $\mathrm{Ba}_{2} \mathrm{Bi}_{4} \mathrm{O}_{8}$. Native defects of $\mathrm{BiCuSeO}$ (Figure 2 in main text) are shown in lighter colors. 


\section{Group-17 Doping: F}

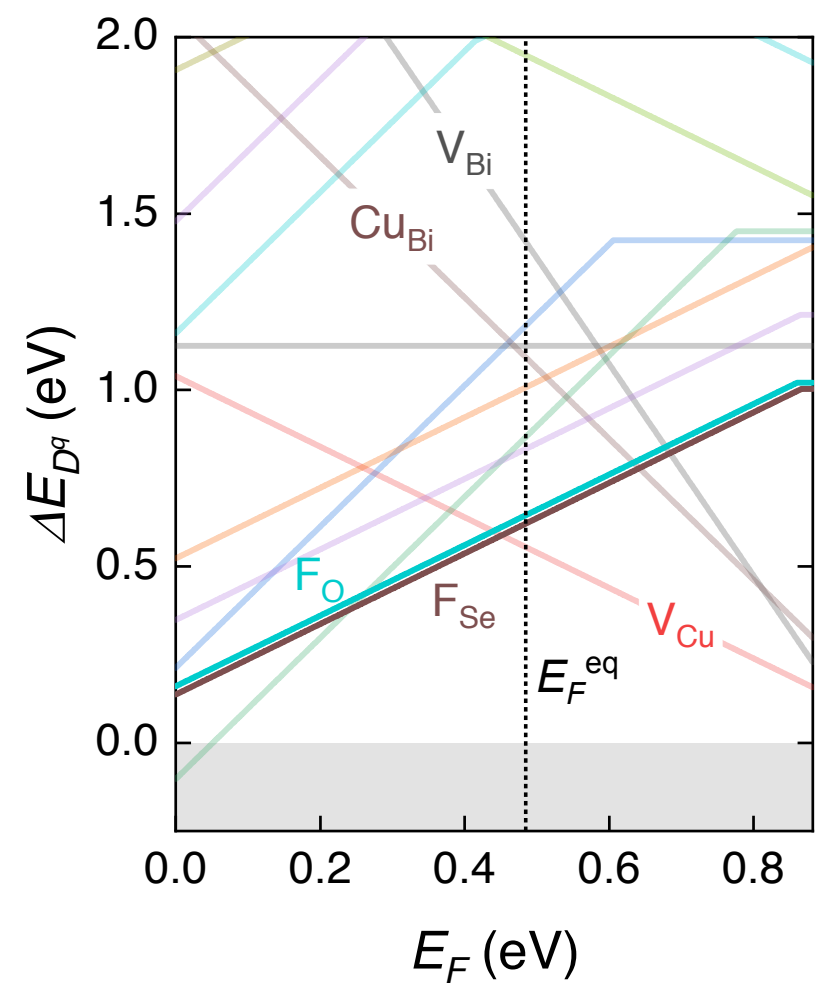

Figure S5: Formation energy of defects associated with $\mathrm{F}$ doping under the most $\mathrm{Cu}$-rich condition, where $\mathrm{BiCuSeO}$ is in equilibrium with $\mathrm{Bi}, \mathrm{Cu}_{2} \mathrm{O}, \mathrm{Cu}_{2} \mathrm{Se}$, and $\mathrm{BiFO}$. Native defects of $\mathrm{BiCuSeO}$ (Figure 2 in main text) are shown in lighter colors. The equilibrium Fermi energy $\left(E_{\mathrm{F}}^{\mathrm{eq}}\right)$, as determined by charge neutrality at $973 \mathrm{~K}$, is marked with a dotted vertical line. 


\section{Group-1 Doping: Li}

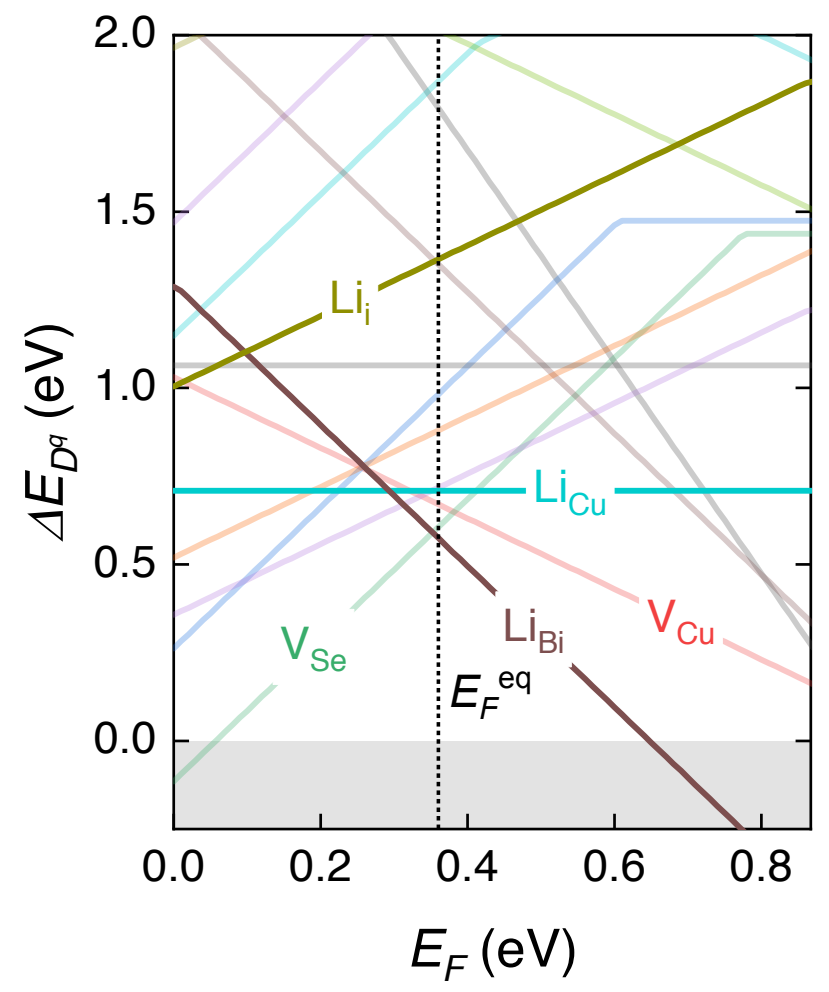

Figure S6: Formation energy of defects associated with $\mathrm{Li}$ doping in $\mathrm{BiCuSeO}$ under the most $\mathrm{Cu}$-rich condition where $\mathrm{BiCuSeO}$ is in equilibrium with $\mathrm{Bi}, \mathrm{Cu}_{2} \mathrm{O}, \mathrm{Bi}_{2} \mathrm{O}_{3}$, and $\mathrm{Cu}_{8} \mathrm{Li}_{8} \mathrm{O}_{8}$. Native defects of $\mathrm{BiCuSeO}$ (Figure 2 in main text) are shown in lighter colors. The equilibrium Fermi energy $\left(E_{\mathrm{F}}^{\mathrm{eq}}\right)$, as determined by charge neutrality at $973 \mathrm{~K}$, is marked with a dotted vertical line. 


\section{Group-12 Doping: Zn}

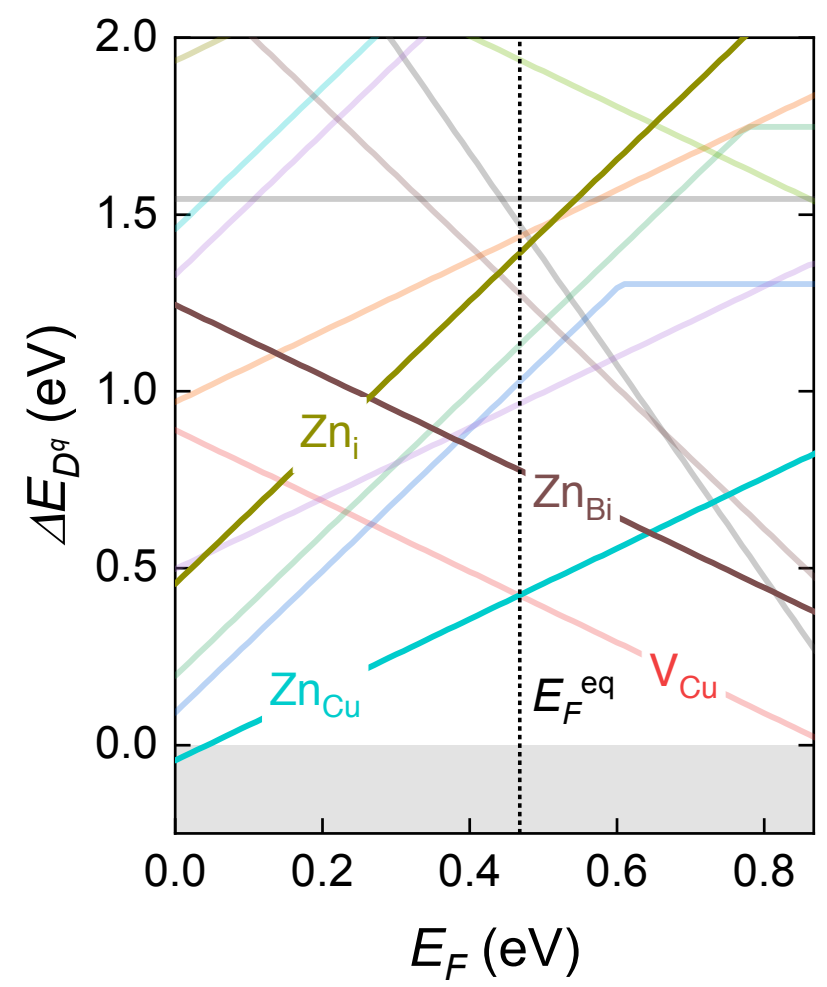

Figure S7: Formation energy of defects associated with $\mathrm{Zn}$ doping in $\mathrm{BiCuSeO}$ under the thermodynamic conditions where $\mathrm{BiCuSeO}$ is in equilibrium with $\mathrm{Bi}, \mathrm{Cu}_{3} \mathrm{Se}_{2}, \mathrm{ZnSe}$, and $\mathrm{ZnO}$. Native defects of $\mathrm{BiCuSeO}$ (Figure 2 in main text) are shown in lighter colors. The equilibrium Fermi energy $\left(E_{\mathrm{F}}^{\mathrm{eq}}\right)$, as determined by charge neutrality at $973 \mathrm{~K}$, is marked with a dotted vertical line. 


\section{Group-3 Doping: Sc, Y}

(a) most Cu-rich/Sc-rich

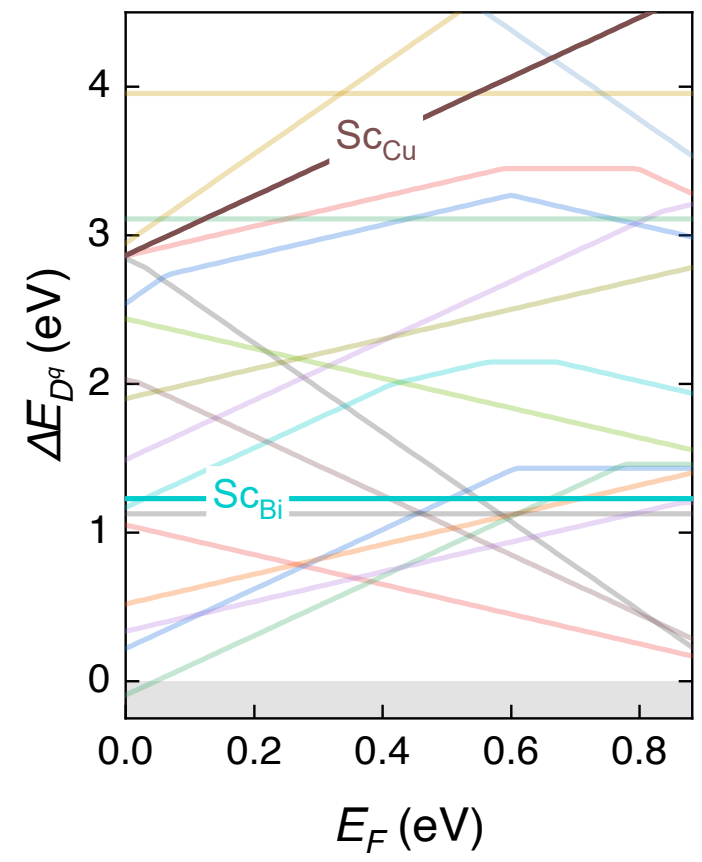

(b) most Cu-rich/Y-rich

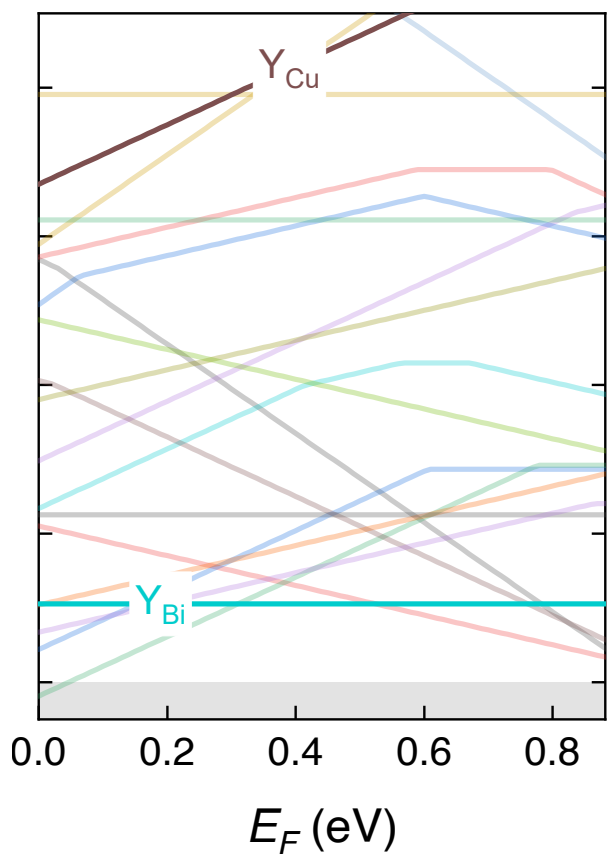

Figure S8: Formation energy of defects associated with (a) Sc, and (b) Y doping in BiCuSeO under the most $\mathrm{Cu}$-rich conditions where $\mathrm{BiCuSeO}$ is in equilibrium with (a) $\mathrm{Bi}, \mathrm{Cu}_{2} \mathrm{Se}, \mathrm{Cu}_{2} \mathrm{O}$, and $\mathrm{CuO}_{2} \mathrm{Sc}$, and (b) $\mathrm{Bi}, \mathrm{Cu}_{2} \mathrm{Se}, \mathrm{Cu}_{2} \mathrm{O}$, and $\mathrm{Y}_{2} \mathrm{O}_{3}$. Native defects of $\mathrm{BiCuSeO}$ (Figure 2 in main text) are shown in lighter colors. The equilibrium Fermi energy $\left(E_{\mathrm{F}}^{\mathrm{eq}}\right)$, as determined by charge neutrality at $973 \mathrm{~K}$, is marked with a dotted vertical line. 


\section{Group-4 Doping: Ti, Zr, Hf}

(a) most Cu-rich/Ti-rich

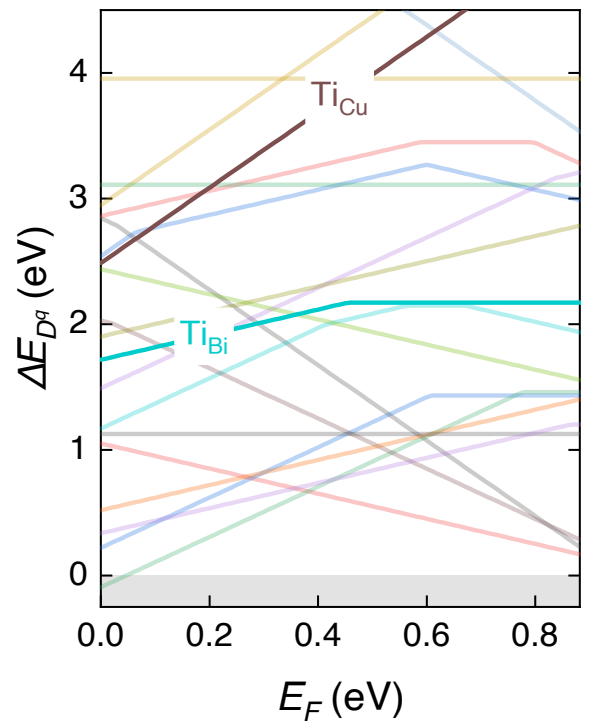

(b) most Cu-rich/Zr-rich

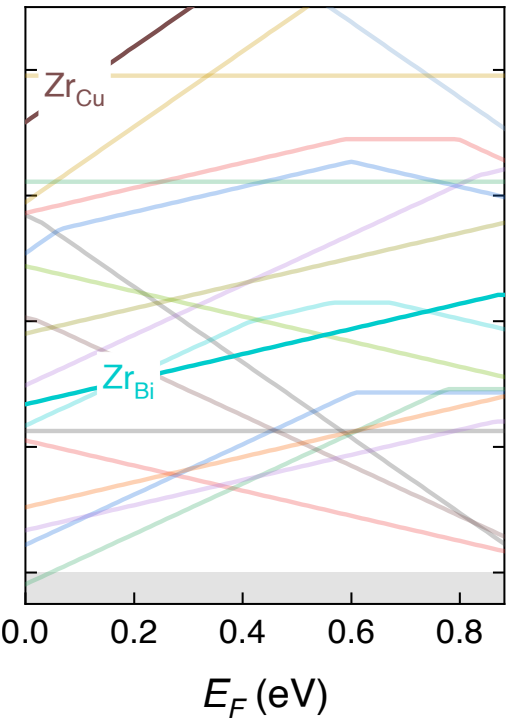

(c) most Cu-rich/Hf-rich

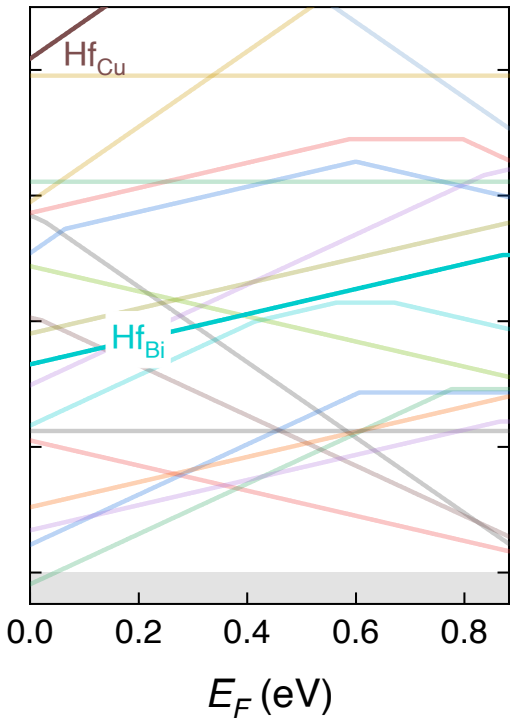

Figure S9: Formation energy of defects associated with (a) Ti, (b) Zr, and (c) Hf doping in BiCuSeO under $\mathrm{Cu}$-rich conditions where $\mathrm{BiCuSeO}$ is in equilibrium with (a) $\mathrm{Bi}, \mathrm{Cu}_{2} \mathrm{Se}, \mathrm{Cu}_{2} \mathrm{O}$, and $\mathrm{Bi}_{2} \mathrm{O}_{7} \mathrm{Ti}_{2}$, (b) $\mathrm{Bi}, \mathrm{Cu}_{2} \mathrm{Se}$, $\mathrm{Cu}_{2} \mathrm{O}$, and $\mathrm{ZrO}_{2}$, and (c) $\mathrm{Bi}, \mathrm{Cu}_{2} \mathrm{Se}, \mathrm{Cu}_{2} \mathrm{O}$, and $\mathrm{HfO}_{2}$. Native defects of $\mathrm{BiCuSeO}$ (Figure 2 in main text) are shown in lighter colors. The equilibrium Fermi energy $\left(E_{\mathrm{F}}^{\mathrm{eq}}\right)$, as determined by charge neutrality at 973 $\mathrm{K}$, is marked with a dotted vertical line. 


\section{Group-13 Doping: Al, Ga, In, and Tl}

(a) most Cu-rich/Al-rich

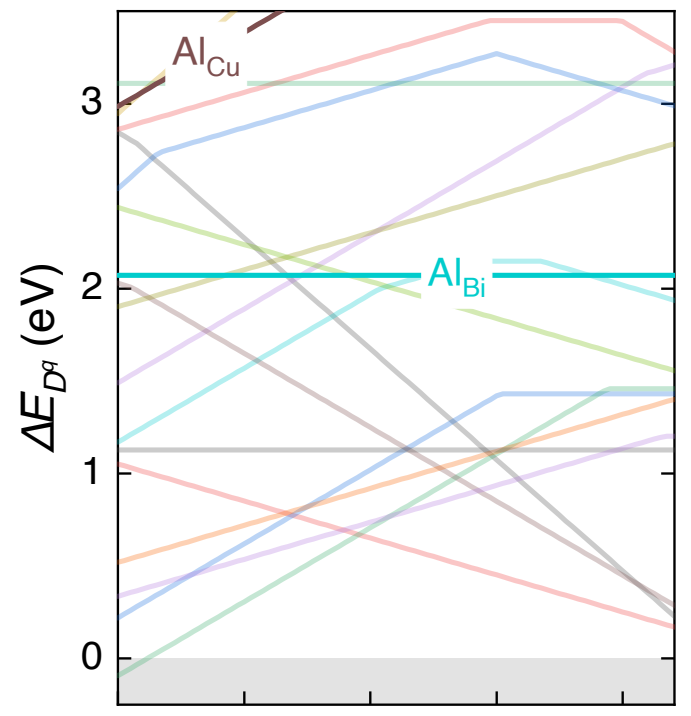

(c) most Cu-rich/In-rich

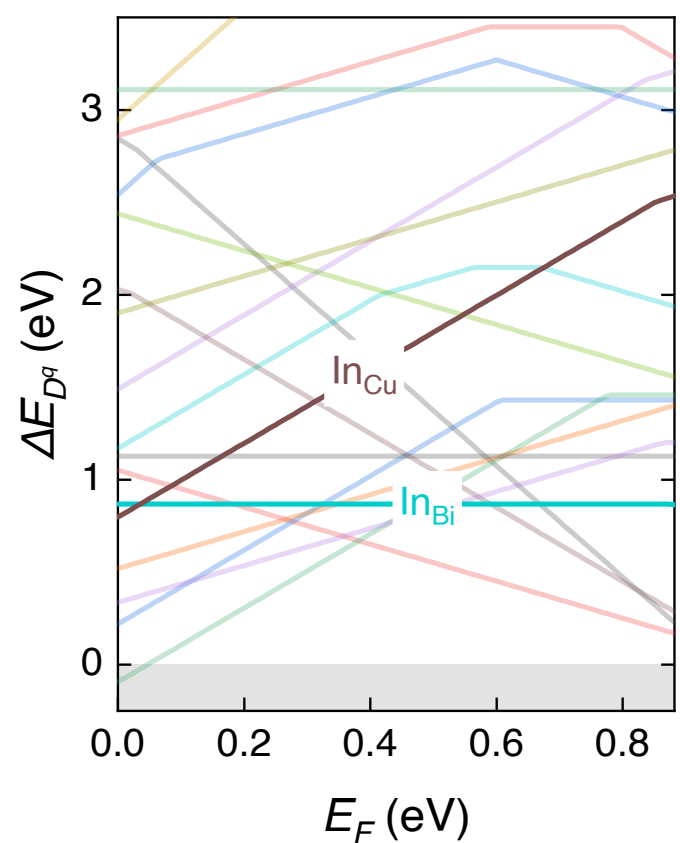

(b) most Cu-rich/Ga-rich

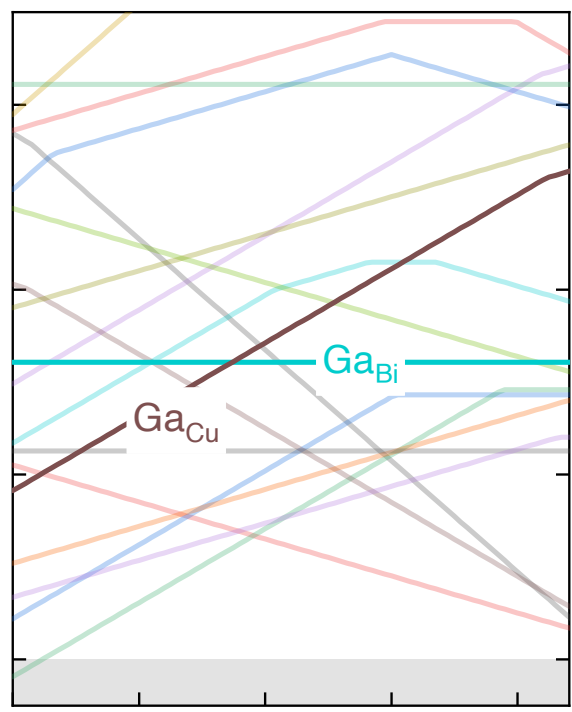

(d) most Cu-rich/TI-rich

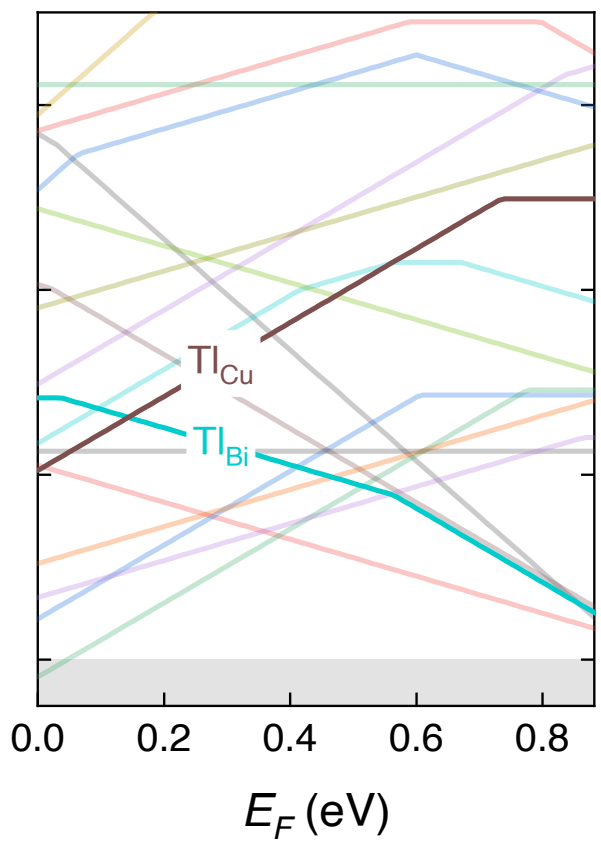

Figure S10: Formation energy of defects associated with (a) Al, (b) Ga, (c) In, and (d) Tl doping in BiCuSeO under $\mathrm{Cu}$-rich conditions where $\mathrm{BiCuSeO}$ is in equilibrium with (a) $\mathrm{Bi}, \mathrm{Cu}_{2} \mathrm{Se}, \mathrm{Cu}_{2} \mathrm{O}$, and $\mathrm{AlCuO}_{2}$, (b) $\mathrm{Bi}$, $\mathrm{Cu}_{2} \mathrm{Se}, \mathrm{Cu}_{2} \mathrm{O}$, and $\mathrm{CuGaO}_{2}$, (c) $\mathrm{Bi}, \mathrm{Cu}_{2} \mathrm{Se}, \mathrm{Cu}_{2} \mathrm{O}$, and $\mathrm{CuInO}_{2}$, and (d) $\mathrm{Bi}, \mathrm{Cu}_{2} \mathrm{Se}, \mathrm{Cu}_{2} \mathrm{O}$, and $\mathrm{Cu}_{2} \mathrm{Se}_{2} \mathrm{Tl}$. Native defects of $\mathrm{BiCuSeO}$ (Figure 2 in main text) are shown in lighter colors. The equilibrium Fermi energy $\left(E_{\mathrm{F}}^{\mathrm{eq}}\right)$, as determined by charge neutrality at $973 \mathrm{~K}$, is marked with a dotted vertical line. 


\section{Group-14 Doping: Si, Ge, Sn, Pb}

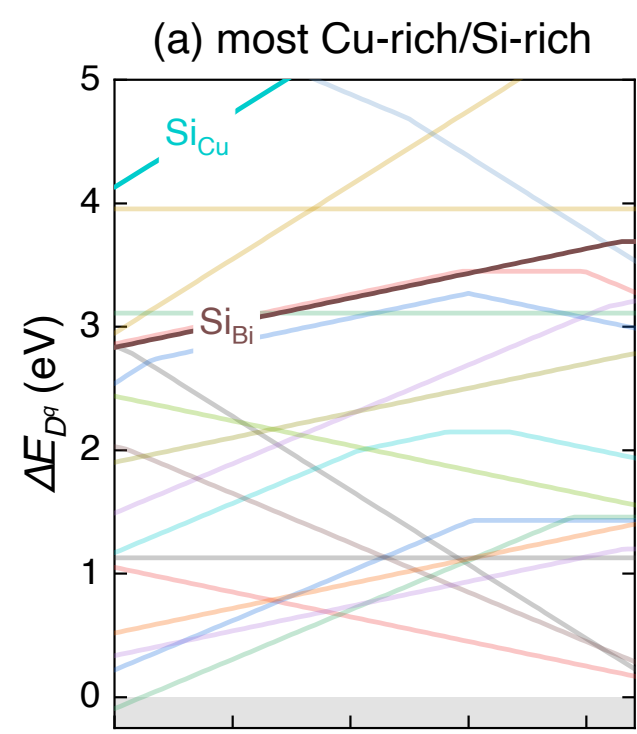

(c) most Cu-rich/Sn-rich

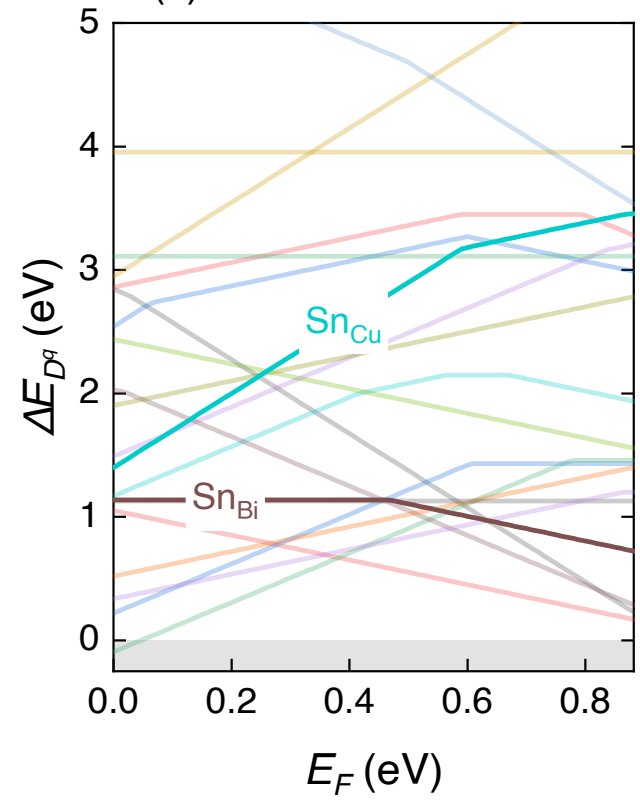

(b) most Cu-rich/Ge-rich

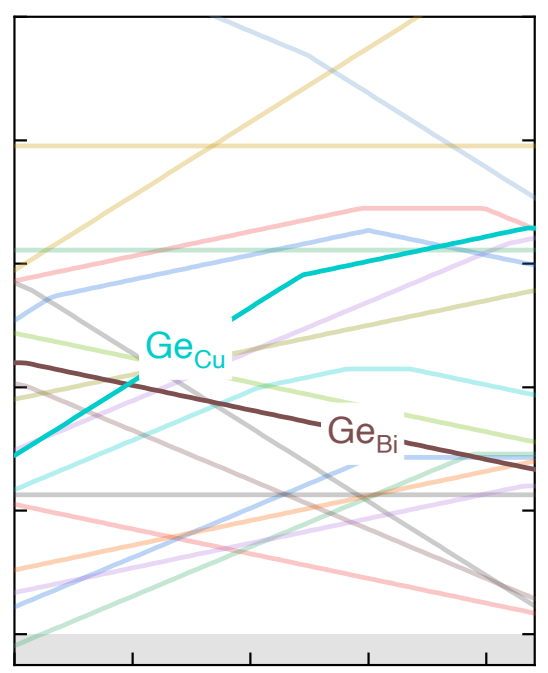

(d) most Cu-rich/Pb-rich

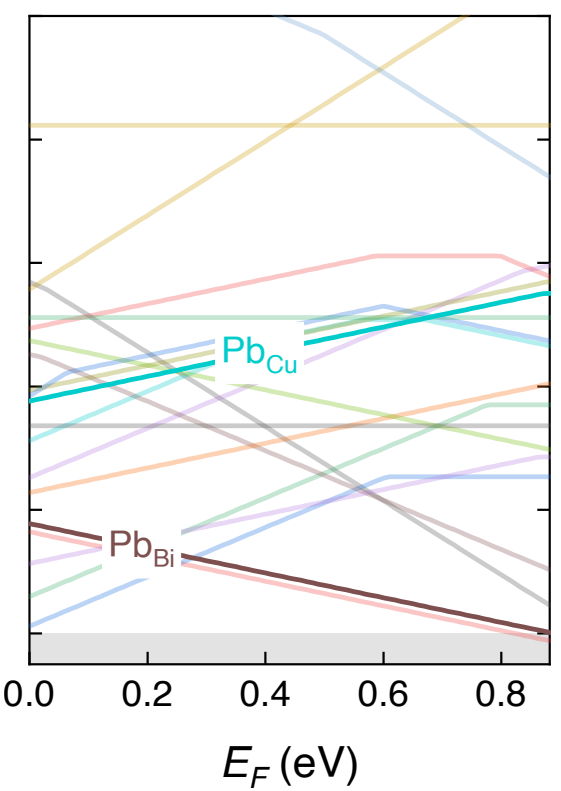

Figure S11: Formation energy of defects associated with (a) Si, (b) Ge, (c) Sn, and (d) Pb doping in BiCuSeO under $\mathrm{Cu}$-rich conditions where $\mathrm{BiCuSeO}$ is in equilibrium with a) $\mathrm{Bi}, \mathrm{Cu}_{2} \mathrm{Se}, \mathrm{Cu}_{2} \mathrm{O}$, and $\mathrm{Bi}_{4} \mathrm{O}_{12} \mathrm{Si}_{3}$, (b) $\mathrm{Bi}$, $\mathrm{Cu}_{2} \mathrm{Se}, \mathrm{Cu}_{2} \mathrm{O}$, and $\mathrm{Bi}_{4} \mathrm{Ge}_{3} \mathrm{O}_{12}$, (c) $\mathrm{Bi}, \mathrm{Cu}_{2} \mathrm{O}, \mathrm{Bi}_{2} \mathrm{O}_{7} \mathrm{Sn}_{2}$, and $\mathrm{Cu}_{2} \mathrm{Se}$, and (d) $\mathrm{Bi}, \mathrm{PbSe}, \mathrm{Cu}_{3} \mathrm{Se}_{2}$, and $\mathrm{Bi}_{2} \mathrm{Se}_{3}$. Native defects of $\mathrm{BiCuSeO}$ (Figure 2 in main text) are shown in lighter colors. The equilibrium Fermi energy $\left(E_{\mathrm{F}}^{\mathrm{eq}}\right)$, as determined by charge neutrality at $973 \mathrm{~K}$, is marked with a dotted vertical line. 


\section{Phase Equilibria of Mg-Doped BiCuSeO}

\begin{tabular}{|c|c|c|c|c|c|c|}
\hline Equilibrium Phases & $\Delta \mu_{\mathrm{Bi}}$ & $\Delta \mu_{\mathrm{Cu}}$ & $\Delta \mu_{\mathrm{Mg}}$ & $\Delta \mu_{\mathrm{O}}$ & $\Delta \mu_{\mathrm{Se}}$ & $p-n\left(\mathrm{~cm}^{-3}\right)$ \\
\hline $\mathrm{Se}, \mathrm{MgO}, \mathrm{Cu}_{3} \mathrm{Se}_{2}, \mathrm{Bi}_{2} \mathrm{Se}_{3}$ & -0.378 & -0.62 & -4.323 & -1.923 & 0.0 & $7.39 \times 10^{19}$ \\
\hline $\mathrm{Se}, \mathrm{MgO}, \mathrm{Bi}_{2} \mathrm{O}_{2} \mathrm{Se}, \mathrm{Bi}_{2} \mathrm{O}_{3}$ & -0.602 & -0.708 & -4.636 & -1.61 & 0.0 & $1.26 \times 10^{20}$ \\
\hline $\mathrm{Se}, \mathrm{MgO}, \mathrm{Bi}_{2} \mathrm{O}_{2} \mathrm{Se}, \mathrm{Bi}_{2} \mathrm{Se}_{3}$ & -0.378 & -0.708 & -4.411 & -1.835 & 0.0 & $1.25 \times 10^{20}$ \\
\hline $\mathrm{Se}, \mathrm{MgO}, \mathrm{Cu}_{3} \mathrm{Se}_{2}, \mathrm{Bi}_{2} \mathrm{O}_{3}$ & -0.865 & -0.62 & -4.811 & -1.435 & 0.0 & $7.53 \times 10^{19}$ \\
\hline $\mathrm{Bi}, \mathrm{MgO}, \mathrm{Bi}_{2} \mathrm{O}_{2} \mathrm{Se}, \mathrm{Bi}_{2} \mathrm{Se}_{3}$ & 0.0 & -0.582 & -4.159 & -2.087 & -0.252 & $5.39 \times 10^{19}$ \\
\hline $\mathrm{Bi}, \mathrm{Cu}_{2} \mathrm{Se}, \mathrm{MgO}, \mathrm{Cu}_{2} \mathrm{O}$ & 0.0 & -0.223 & -4.192 & -2.054 & -0.643 & $5.24 \times 10^{18}$ \\
\hline $\mathrm{Bi}, \mathrm{MgO}, \mathrm{Cu}_{2} \mathrm{O}, \mathrm{Bi}_{2} \mathrm{O}_{3}$ & 0.0 & -0.244 & -4.234 & -2.012 & -0.664 & $5.67 \times 10^{18}$ \\
\hline $\mathrm{Bi}, \mathrm{MgO}, \mathrm{Bi}_{2} \mathrm{O}_{2} \mathrm{Se}, \mathrm{Bi}_{2} \mathrm{O}_{3}$ & 0.0 & -0.507 & -4.234 & -2.012 & -0.402 & $3.45 \times 10^{19}$ \\
\hline $\mathrm{Bi}, \mathrm{MgO}, \mathrm{Cu}_{3} \mathrm{Se}_{2}, \mathrm{Bi}_{2} \mathrm{Se}_{3}$ & 0.0 & -0.452 & -4.03 & -2.216 & -0.252 & $2.36 \times 10^{19}$ \\
\hline $\mathrm{Bi}, \mathrm{Cu}_{2} \mathrm{Se}, \mathrm{MgO}, \mathrm{Cu}_{3} \mathrm{Se}_{2}$ & 0.0 & -0.318 & -4.097 & -2.149 & -0.453 & $1.12 \times 10^{19}$ \\
\hline $\mathrm{MgO}, \mathrm{Cu}_{3} \mathrm{Se}_{2}, \mathrm{Cu}_{2} \mathrm{O}, \mathrm{Bi}_{2} \mathrm{O}_{3}$ & -0.603 & -0.445 & -4.636 & -1.61 & -0.262 & $2.63 \times 10^{19}$ \\
\hline $\mathrm{Cu}_{2} \mathrm{Se}, \mathrm{MgO}, \mathrm{Cu}_{3} \mathrm{Se}_{2}, \mathrm{Cu}_{2} \mathrm{O}$ & -0.285 & -0.318 & -4.382 & -1.864 & -0.453 & $1.16 \times 10^{19}$ \\
\hline
\end{tabular}

Table S4: Chemical potentials $\Delta \mu_{\mathrm{i}}$ (in eV) in all phase regions of the quinary Bi-Cu-Se-O-Mg phase space that are in equilibrium with $\mathrm{BiCuSeO}$. The corresponding charge carrier concentration in each phase region, as determined by charge neutrality at the typical synthesis temperature of $973 \mathrm{~K}$, is listed. 


\section{Phase Equilibria of Ca-Doped BiCuSeO}

\begin{tabular}{|c|c|c|c|c|c|c|}
\hline Equilibrium Phases & $\Delta \mu_{\mathrm{Bi}}$ & $\Delta \mu_{\mathrm{Ca}}$ & $\Delta \mu_{\mathrm{Cu}}$ & $\Delta \mu_{\mathrm{O}}$ & $\Delta \mu_{\mathrm{Se}}$ & $p-n\left(\mathrm{~cm}^{-3}\right)$ \\
\hline $\mathrm{Se}, \mathrm{CaO}, \mathrm{Cu}_{3} \mathrm{Se}_{2}, \mathrm{Bi}_{2} \mathrm{Se}_{3}$ & -0.378 & -4.659 & -0.62 & -1.923 & 0.0 & $1.38 \times 10^{21}$ \\
\hline $\mathrm{Se}, \mathrm{CaO}, \mathrm{CaO}_{3} \mathrm{Se}, \mathrm{Bi}_{2} \mathrm{Se}_{3}$ & -0.378 & -4.723 & -0.684 & -1.859 & 0.0 & $1.19 \times 10^{21}$ \\
\hline $\mathrm{Se}, \mathrm{Bi}_{2} \mathrm{O}_{2} \mathrm{Se}, \mathrm{CaO}_{3} \mathrm{Se}, \mathrm{Bi}_{2} \mathrm{Se}_{3}$ & -0.378 & -4.795 & -0.708 & -1.835 & 0.0 & $8.89 \times 10^{20}$ \\
\hline $\mathrm{Se}, \mathrm{CaO}, \mathrm{Cu}_{3} \mathrm{Se}_{2}, \mathrm{CaO}_{3} \mathrm{Se}$ & -0.441 & -4.723 & -0.62 & -1.859 & 0.0 & $1.53 \times 10^{21}$ \\
\hline $\mathrm{Se}, \mathrm{Cu}_{3} \mathrm{Se}_{2}, \mathrm{Bi}_{2} \mathrm{O}_{3}, \mathrm{CaO}_{3} \mathrm{Se}$ & -0.865 & -5.995 & -0.62 & -1.435 & 0.0 & $7.65 \times 10^{19}$ \\
\hline $\mathrm{Se}, \mathrm{Bi}_{2} \mathrm{O}_{2} \mathrm{Se}, \mathrm{Bi}_{2} \mathrm{O}_{3}, \mathrm{CaO}_{3} \mathrm{Se}$ & -0.602 & -5.47 & -0.708 & -1.61 & 0.0 & $1.45 \times 10^{20}$ \\
\hline $\mathrm{Bi}, \mathrm{CaO}, \mathrm{Cu}_{2} \mathrm{O}, \mathrm{Bi}_{2} \mathrm{O}_{3}$ & 0.0 & -4.57 & -0.244 & -2.012 & -0.664 & $1.11 \times 10^{20}$ \\
\hline $\mathrm{Bi}, \mathrm{CaO}, \mathrm{Cu}_{2} \mathrm{Se}, \mathrm{Cu}_{2} \mathrm{O}$ & 0.0 & -4.528 & -0.223 & -2.054 & -0.643 & $1.41 \times 10^{20}$ \\
\hline $\mathrm{Bi}, \mathrm{CaO}, \mathrm{Bi}_{2} \mathrm{O}_{2} \mathrm{Se}, \mathrm{Bi}_{2} \mathrm{Se}_{3}$ & 0.0 & -4.495 & -0.582 & -2.087 & -0.252 & $3.88 \times 10^{20}$ \\
\hline $\mathrm{Bi}, \mathrm{CaO}, \mathrm{Bi}_{2} \mathrm{O}_{2} \mathrm{Se}, \mathrm{Bi}_{2} \mathrm{O}_{3}$ & 0.0 & -4.57 & -0.507 & -2.012 & -0.402 & $2.53 \times 10^{20}$ \\
\hline $\mathrm{Bi}, \mathrm{CaO}, \mathrm{Cu}_{3} \mathrm{Se}_{2}, \mathrm{Bi}_{2} \mathrm{Se}_{3}$ & 0.0 & -4.366 & -0.452 & -2.216 & -0.252 & $4.48 \times 10^{20}$ \\
\hline $\mathrm{Bi}, \mathrm{CaO}, \mathrm{Cu}_{2} \mathrm{Se}, \mathrm{Cu}_{3} \mathrm{Se}_{2}$ & 0.0 & -4.433 & -0.318 & -2.149 & -0.453 & $3.44 \times 10^{20}$ \\
\hline $\mathrm{CaO}, \mathrm{Bi}_{2} \mathrm{O}_{2} \mathrm{Se}, \mathrm{CaO}_{3} \mathrm{Se}, \mathrm{Bi}_{2} \mathrm{Se}_{3}$ & -0.354 & -4.731 & -0.7 & -1.851 & -0.016 & $1.05 \times 10^{21}$ \\
\hline $\mathrm{CaO}, \mathrm{Cu}_{2} \mathrm{Se}, \mathrm{Cu}_{2} \mathrm{O}, \mathrm{Cu}_{3} \mathrm{Se}_{2}$ & -0.285 & -4.718 & -0.318 & -1.864 & -0.453 & $3.95 \times 10^{20}$ \\
\hline $\mathrm{CaO}, \mathrm{Bi}_{2} \mathrm{O}_{2} \mathrm{Se}, \mathrm{Bi}_{2} \mathrm{O}_{3}, \mathrm{CaO}_{3} \mathrm{Se}$ & -0.353 & -4.806 & -0.625 & -1.776 & -0.166 & $7 \times 10^{20}$ \\
\hline $\mathrm{CaO}, \mathrm{Cu}_{2} \mathrm{O}, \mathrm{Bi}_{2} \mathrm{O}_{3}, \mathrm{CaO}_{3} \mathrm{Se}$ & -0.485 & -4.894 & -0.406 & -1.688 & -0.341 & $6.1 \times 10^{20}$ \\
\hline $\mathrm{Cu}_{2} \mathrm{O}, \mathrm{Cu}_{3} \mathrm{Se}_{2}, \mathrm{Bi}_{2} \mathrm{O}_{3}, \mathrm{CaO}_{3} \mathrm{Se}$ & -0.603 & -5.208 & -0.445 & -1.61 & -0.262 & $2.97 \times 10^{20}$ \\
\hline $\mathrm{CaO}, \mathrm{Cu}_{2} \mathrm{O}, \mathrm{Cu}_{3} \mathrm{Se}_{2}, \mathrm{CaO}_{3} \mathrm{Se}$ & -0.496 & -4.886 & -0.402 & -1.696 & -0.327 & $6.81 \times 10^{20}$ \\
\hline
\end{tabular}

Table S5: Chemical potentials $\Delta \mu_{\mathrm{i}}$ (in eV) in all phase regions of the quinary Bi-Cu-Se-O-Ca phase space that are in equilibrium with $\mathrm{BiCuSeO}$. The corresponding charge carrier concentration in each phase region, as determined by charge neutrality at the typical synthesis temperature of $973 \mathrm{~K}$, is listed. 


\section{Phase Equilibria of Sr-Doped BiCuSeO}

\begin{tabular}{|c|c|c|c|c|c|c|}
\hline Equilibrium Phases & $\Delta \mu_{\mathrm{Bi}}$ & $\Delta \mu_{\mathrm{Cu}}$ & $\Delta \mu_{\mathrm{O}}$ & $\Delta \mu_{\mathrm{Se}}$ & $\Delta \mu_{\mathrm{Sr}}$ & $p-n\left(\mathrm{~cm}^{-3}\right)$ \\
\hline $\mathrm{Bi}, \mathrm{SeSr}, \mathrm{Cu}_{3} \mathrm{Se}_{2}, \mathrm{Bi}_{2} \mathrm{Se}_{3}$ & 0.0 & -0.452 & -2.216 & -0.252 & -4.274 & $5.95 \times 10^{20}$ \\
\hline $\mathrm{Bi}, \mathrm{Cu}_{2} \mathrm{O}, \mathrm{Bi}_{2} \mathrm{O}_{3}, \mathrm{Bi}_{2} \mathrm{O}_{4} \mathrm{Sr}$ & 0.0 & -0.244 & -2.012 & -0.664 & -4.72 & $5.66 \times 10^{19}$ \\
\hline $\mathrm{Bi}, \mathrm{Cu}_{2} \mathrm{Se}, \mathrm{Cu}_{2} \mathrm{O}, \mathrm{Bi}_{2} \mathrm{O}_{4} \mathrm{Sr}$ & 0.0 & -0.223 & -2.054 & -0.643 & -4.551 & $1.2 \times 10^{20}$ \\
\hline $\mathrm{Bi}, \mathrm{Cu}_{2} \mathrm{Se}, \mathrm{Bi}_{2} \mathrm{O}_{5} \mathrm{Sr}_{2}, \mathrm{Bi}_{2} \mathrm{O}_{4} \mathrm{Sr}$ & 0.0 & -0.258 & -2.089 & -0.573 & -4.411 & $2.66 \times 10^{20}$ \\
\hline $\mathrm{Bi}, \mathrm{Cu}_{2} \mathrm{Se}, \mathrm{Bi}_{2} \mathrm{O}_{5} \mathrm{Sr}_{2}, \mathrm{Cu}_{3} \mathrm{Se}_{2}$ & 0.0 & -0.318 & -2.149 & -0.453 & -4.261 & $6.19 \times 10^{20}$ \\
\hline $\mathrm{Bi}, \mathrm{SeSr}, \mathrm{Bi}_{2} \mathrm{O}_{5} \mathrm{Sr}_{2}, \mathrm{Cu}_{3} \mathrm{Se}_{2}$ & 0.0 & -0.386 & -2.183 & -0.351 & -4.175 & $8.91 \times 10^{20}$ \\
\hline $\mathrm{O}_{3} \mathrm{SeSr}, \mathrm{SeSr}, \mathrm{Cu}_{3} \mathrm{Se}_{2}, \mathrm{Bi}_{2} \mathrm{Se}_{3}$ & -0.313 & -0.591 & -1.973 & -0.043 & -4.483 & $1.7 \times 10^{21}$ \\
\hline $\mathrm{O}_{3} \mathrm{SeSr}, \mathrm{SeSr}, \mathrm{Bi}_{2} \mathrm{O}_{5} \mathrm{Sr}_{2}, \mathrm{Bi}_{2} \mathrm{Se}_{3}$ & -0.256 & -0.61 & -1.973 & -0.081 & -4.445 & $1.59 \times 10^{21}$ \\
\hline $\mathrm{O}_{3} \mathrm{SeSr}, \mathrm{Bi}_{2} \mathrm{O}_{5} \mathrm{Sr}_{2}, \mathrm{Bi}_{2} \mathrm{O}_{4} \mathrm{Sr}, \mathrm{Bi}_{2} \mathrm{Se}_{3}$ & -0.242 & -0.66 & -1.927 & -0.09 & -4.573 & $1.05 \times 10^{21}$ \\
\hline $\mathrm{O}_{3} \mathrm{SeSr}, \mathrm{Bi}_{2} \mathrm{O}_{2} \mathrm{Se}, \mathrm{Bi}_{2} \mathrm{O}_{4} \mathrm{Sr}, \mathrm{Bi}_{2} \mathrm{Se}_{3}$ & -0.244 & -0.663 & -1.924 & -0.089 & -4.583 & $1.02 \times 10^{21}$ \\
\hline $\mathrm{O}_{3} \mathrm{SeSr}, \mathrm{Cu}_{2} \mathrm{O}, \mathrm{Cu}_{3} \mathrm{Se}_{2}, \mathrm{Bi}_{2} \mathrm{O}_{4} \mathrm{Sr}$ & -0.474 & -0.394 & -1.712 & -0.339 & -4.968 & $4.02 \times 10^{20}$ \\
\hline $\mathrm{O}_{3} \mathrm{SeSr}, \mathrm{Bi}_{2} \mathrm{O}_{5} \mathrm{Sr}_{2}, \mathrm{Cu}_{3} \mathrm{Se}_{2}, \mathrm{Bi}_{2} \mathrm{O}_{4} \mathrm{Sr}$ & -0.371 & -0.445 & -1.842 & -0.262 & -4.658 & $1.09 \times 10^{21}$ \\
\hline $\mathrm{O}_{3} \mathrm{SeSr}, \mathrm{Cu}_{2} \mathrm{O}, \mathrm{Cu}_{3} \mathrm{Se}_{2}, \mathrm{Bi}_{2} \mathrm{O}_{3}$ & -0.603 & -0.445 & -1.61 & -0.262 & -5.353 & $1.29 \times 10^{20}$ \\
\hline $\mathrm{O}_{3} \mathrm{SeSr}, \mathrm{SeSr}, \mathrm{Bi}_{2} \mathrm{O}_{5} \mathrm{Sr}_{2}, \mathrm{Cu}_{3} \mathrm{Se}_{2}$ & -0.289 & -0.544 & -1.973 & -0.114 & -4.412 & $1.92 \times 10^{21}$ \\
\hline $\mathrm{O}_{3} \mathrm{SeSr}, \mathrm{Bi}_{2} \mathrm{O}_{2} \mathrm{Se}, \mathrm{Bi}_{2} \mathrm{O}_{3}, \mathrm{Bi}_{2} \mathrm{O}_{4} \mathrm{Sr}$ & -0.356 & -0.625 & -1.774 & -0.164 & -4.958 & $3.1 \times 10^{20}$ \\
\hline $\mathrm{O}_{3} \mathrm{SeSr}, \mathrm{Cu}_{2} \mathrm{O}, \mathrm{Bi}_{2} \mathrm{O}_{3}, \mathrm{Bi}_{2} \mathrm{O}_{4} \mathrm{Sr}$ & -0.487 & -0.407 & -1.687 & -0.339 & -5.045 & $3.03 \times 10^{20}$ \\
\hline $\mathrm{Cu}_{2} \mathrm{Se}, \mathrm{Bi}_{2} \mathrm{O}_{5} \mathrm{Sr}_{2}, \mathrm{Cu}_{3} \mathrm{Se}_{2}, \mathrm{Bi}_{2} \mathrm{O}_{4} \mathrm{Sr}$ & -0.18 & -0.318 & -1.969 & -0.453 & -4.531 & $5.04 \times 10^{20}$ \\
\hline $\mathrm{Cu}_{2} \mathrm{Se}, \mathrm{Cu}_{2} \mathrm{O}, \mathrm{Cu}_{3} \mathrm{Se}_{2}, \mathrm{Bi}_{2} \mathrm{O}_{4} \mathrm{Sr}$ & -0.285 & -0.318 & -1.864 & -0.453 & -4.741 & $3.4 \times 10^{20}$ \\
\hline $\mathrm{Se}, \mathrm{O}_{3} \mathrm{SeSr}, \mathrm{Bi}_{2} \mathrm{O}_{2} \mathrm{Se}, \mathrm{Bi}_{2} \mathrm{O}_{3}$ & -0.603 & -0.708 & -1.61 & 0.0 & -5.615 & $1.29 \times 10^{20}$ \\
\hline $\mathrm{Se}, \mathrm{O}_{3} \mathrm{SeSr}, \mathrm{Cu}_{3} \mathrm{Se}_{2}, \mathrm{Bi}_{2} \mathrm{O}_{3}$ & -0.865 & -0.62 & -1.435 & 0.0 & -6.14 & $7.53 \times 10^{19}$ \\
\hline $\mathrm{Se}, \mathrm{O}_{3} \mathrm{SeSr}, \mathrm{Bi}_{2} \mathrm{O}_{2} \mathrm{Se}, \mathrm{Bi}_{2} \mathrm{Se}_{3}$ & -0.378 & -0.708 & -1.835 & 0.0 & -4.94 & $4.03 \times 10^{20}$ \\
\hline $\mathrm{Se}, \mathrm{O}_{3} \mathrm{SeSr}, \mathrm{Cu}_{3} \mathrm{Se}_{2}, \mathrm{Bi}_{2} \mathrm{Se}_{3}$ & -0.378 & -0.62 & -1.923 & 0.0 & -4.677 & $1.22 \times 10^{21}$ \\
\hline
\end{tabular}

Table S6: Chemical potentials $\Delta \mu_{\mathrm{i}}$ (in eV) in all phase regions of the quinary Bi-Cu-Se-O-Sr phase space that are in equilibrium with $\mathrm{BiCuSeO}$. The corresponding charge carrier concentration in each phase region, as determined by charge neutrality at the typical synthesis temperature of $973 \mathrm{~K}$, is listed. 


\section{Phase Equilibria of Ba-Doped BiCuSeO}

\begin{tabular}{|c|c|c|c|c|c|c|}
\hline Equilibrium Phases & $\Delta \mu_{\mathrm{Ba}}$ & $\Delta \mu_{\mathrm{Bi}}$ & $\Delta \mu_{\mathrm{Cu}}$ & $\Delta \mu_{\mathrm{O}}$ & $\Delta \mu_{\mathrm{Se}}$ & $p-n\left(\mathrm{~cm}^{-3}\right)$ \\
\hline $\mathrm{Se}, \mathrm{Bi}_{2} \mathrm{Se}_{3}, \mathrm{BaO}_{3} \mathrm{Se}, \mathrm{Cu}_{3} \mathrm{Se}_{2}$ & -4.722 & -0.378 & -0.62 & -1.923 & 0.0 & $8.82 \times 10^{19}$ \\
\hline $\mathrm{Se}, \mathrm{Bi}_{2} \mathrm{Se}_{3}, \mathrm{Bi}_{2} \mathrm{O}_{2} \mathrm{Se}, \mathrm{BaO}_{3} \mathrm{Se}$ & -4.985 & -0.378 & -0.708 & -1.835 & 0.0 & $1.25 \times 10^{20}$ \\
\hline $\mathrm{Se}, \mathrm{BaO}_{3} \mathrm{Se}, \mathrm{Cu}_{3} \mathrm{Se}_{2}, \mathrm{Bi}_{2} \mathrm{O}_{3}$ & -6.185 & -0.865 & -0.62 & -1.435 & 0.0 & $7.5 \times 10^{19}$ \\
\hline $\mathrm{Se}, \mathrm{Bi}_{2} \mathrm{O}_{2} \mathrm{Se}, \mathrm{BaO}_{3} \mathrm{Se}, \mathrm{Bi}_{2} \mathrm{O}_{3}$ & -5.66 & -0.603 & -0.708 & -1.61 & 0.0 & $1.26 \times 10^{20}$ \\
\hline $\mathrm{Bi}_{2} \mathrm{Se}_{3}, \mathrm{BaSe}, \mathrm{BaBiSe}_{3}, \mathrm{BaCu}_{2} \mathrm{Se}_{2}$ & -4.399 & -0.169 & -0.609 & -2.003 & -0.139 & $1.12 \times 10^{20}$ \\
\hline $\mathrm{Bi}_{2} \mathrm{Se}_{3}, \mathrm{BaCu}_{2} \mathrm{Se}_{2}, \mathrm{BaO}_{3} \mathrm{Se}, \mathrm{Cu}_{3} \mathrm{Se}_{2}$ & -4.643 & -0.351 & -0.608 & -1.943 & -0.018 & $9.45 \times 10^{19}$ \\
\hline $\mathrm{Bi}_{2} \mathrm{Se}_{3}, \mathrm{BaBiSe}_{3}, \mathrm{BaCu}_{2} \mathrm{Se}_{2}, \mathrm{BaO}_{3} \mathrm{Se}$ & -4.448 & -0.218 & -0.617 & -1.979 & -0.106 & $1.16 \times 10^{20}$ \\
\hline $\mathrm{Bi}_{2} \mathrm{Se}_{3}, \mathrm{BaSe}, \mathrm{Bi}_{2} \mathrm{O}_{2} \mathrm{Se}, \mathrm{BaO}_{3} \mathrm{Se}$ & -4.389 & -0.154 & -0.633 & -1.984 & -0.149 & $1.17 \times 10^{20}$ \\
\hline $\mathrm{Bi}_{2} \mathrm{Se}_{3}, \mathrm{BaSe}, \mathrm{BaBiSe}_{3}, \mathrm{BaO}_{3} \mathrm{Se}$ & -4.399 & -0.169 & -0.628 & -1.984 & -0.139 & $1.18 \times 10^{20}$ \\
\hline $\mathrm{Cu}_{2} \mathrm{O}, \mathrm{BaO}_{3} \mathrm{Se}, \mathrm{Cu}_{3} \mathrm{Se}_{2}, \mathrm{Ba}_{2} \mathrm{Bi}_{4} \mathrm{O}_{8}$ & -4.706 & -0.372 & -0.353 & -1.795 & -0.401 & $4.84 \times 10^{19}$ \\
\hline $\mathrm{BaCu}_{2} \mathrm{Se}_{2}, \mathrm{BaO}_{3} \mathrm{Se}, \mathrm{Cu}_{3} \mathrm{Se}_{2}, \mathrm{Ba}_{2} \mathrm{Bi}_{4} \mathrm{O}_{8}$ & -4.433 & -0.281 & -0.398 & -1.908 & -0.333 & $1.33 \times 10^{20}$ \\
\hline $\mathrm{Cu}_{2} \mathrm{O}, \mathrm{BaO}_{3} \mathrm{Se}, \mathrm{Cu}_{3} \mathrm{Se}_{2}, \mathrm{Bi}_{2} \mathrm{O}_{3}$ & -5.398 & -0.603 & -0.445 & -1.61 & -0.262 & $2.62 \times 10^{19}$ \\
\hline $\mathrm{Cu}_{2} \mathrm{O}, \mathrm{BaO}_{3} \mathrm{Se}, \mathrm{Bi}_{2} \mathrm{O}_{3}, \mathrm{Ba}_{2} \mathrm{Bi}_{4} \mathrm{O}_{8}$ & -4.844 & -0.395 & -0.376 & -1.748 & -0.401 & $2.94 \times 10^{19}$ \\
\hline $\mathrm{Bi}_{2} \mathrm{O}_{2} \mathrm{Se}, \mathrm{BaO}_{3} \mathrm{Se}, \mathrm{Bi}_{2} \mathrm{O}_{3}, \mathrm{Ba}_{2} \mathrm{Bi}_{4} \mathrm{O}_{8}$ & -4.757 & -0.264 & -0.595 & -1.836 & -0.226 & $6.61 \times 10^{19}$ \\
\hline $\mathrm{BaSe}, \mathrm{Bi}_{2} \mathrm{O}_{2} \mathrm{Se}, \mathrm{BaO}_{3} \mathrm{Se}, \mathrm{Ba}_{2} \mathrm{Bi}_{4} \mathrm{O}_{8}$ & -4.386 & -0.153 & -0.632 & -1.984 & -0.152 & $1.17 \times 10^{20}$ \\
\hline $\mathrm{BaSe}, \mathrm{BaCu}_{2} \mathrm{Se}_{2}, \mathrm{BaO}_{3} \mathrm{Se}, \mathrm{Ba}_{2} \mathrm{Bi}_{4} \mathrm{O}_{8}$ & -4.357 & -0.167 & -0.588 & -1.984 & -0.181 & $1.28 \times 10^{20}$ \\
\hline $\mathrm{BaSe}, \mathrm{BaBiSe}_{3}, \mathrm{BaCu}_{2} \mathrm{Se}_{2}, \mathrm{BaO}_{3} \mathrm{Se}$ & -4.412 & -0.194 & -0.615 & -1.984 & -0.126 & $1.2 \times 10^{20}$ \\
\hline $\mathrm{BaCu}_{2} \mathrm{Se}_{2}, \mathrm{Cu}_{3} \mathrm{Se}_{2}, \mathrm{Cu}_{2} \mathrm{Se}, \mathrm{Ba}_{2} \mathrm{Bi}_{4} \mathrm{O}_{8}$ & -4.353 & -0.161 & -0.318 & -1.988 & -0.453 & $8.68 \times 10^{19}$ \\
\hline $\mathrm{Cu}_{2} \mathrm{O}, \mathrm{Cu}_{3} \mathrm{Se}_{2}, \mathrm{Cu}_{2} \mathrm{Se}, \mathrm{Ba}_{2} \mathrm{Bi}_{4} \mathrm{O}_{8}$ & -4.601 & -0.285 & -0.318 & -1.864 & -0.453 & $4.84 \times 10^{19}$ \\
\hline $\mathrm{Bi}, \mathrm{Cu}_{2} \mathrm{O}, \mathrm{Cu}_{2} \mathrm{Se}, \mathrm{Ba}_{2} \mathrm{Bi}_{4} \mathrm{O}_{8}$ & -4.411 & 0.0 & -0.223 & -2.054 & -0.643 & $1.93 \times 10^{19}$ \\
\hline $\mathrm{Bi}, \mathrm{BaCu}_{2} \mathrm{Se}_{2}, \mathrm{Cu}_{2} \mathrm{Se}, \mathrm{Ba}_{2} \mathrm{Bi}_{4} \mathrm{O}_{8}$ & -4.246 & 0.0 & -0.264 & -2.095 & -0.56 & $5.07 \times 10^{19}$ \\
\hline $\mathrm{Bi}, \mathrm{Cu}_{2} \mathrm{O}, \mathrm{Bi}_{2} \mathrm{O}_{3}, \mathrm{Ba}_{2} \mathrm{Bi}_{4} \mathrm{O}_{8}$ & -4.581 & 0.0 & -0.244 & -2.012 & -0.664 & $9.38 \times 10^{18}$ \\
\hline $\mathrm{Bi}, \mathrm{BaCu}_{2} \mathrm{Se}_{2}, \mathrm{Cu}_{3} \mathrm{Se}_{2}, \mathrm{Cu}_{2} \mathrm{Se}$ & -4.353 & 0.0 & -0.318 & -2.149 & -0.453 & $3.76 \times 10^{19}$ \\
\hline $\mathrm{Bi}, \mathrm{Bi}_{2} \mathrm{Se}_{3}, \mathrm{BaCu}_{2} \mathrm{Se}_{2}, \mathrm{Cu}_{3} \mathrm{Se}_{2}$ & -4.487 & 0.0 & -0.452 & -2.216 & -0.252 & $2.87 \times 10^{19}$ \\
\hline $\mathrm{Bi}, \mathrm{BaSe}, \mathrm{BaCu}_{2} \mathrm{Se}_{2}, \mathrm{Ba}_{2} \mathrm{Bi}_{4} \mathrm{O}_{8}$ & -4.246 & 0.0 & -0.532 & -2.095 & -0.292 & $8.36 \times 10^{19}$ \\
\hline $\mathrm{Bi}, \mathrm{Bi}_{2} \mathrm{O}_{2} \mathrm{Se}, \mathrm{Bi}_{2} \mathrm{O}_{3}, \mathrm{Ba}_{2} \mathrm{Bi}_{4} \mathrm{O}_{8}$ & -4.581 & 0.0 & -0.507 & -2.012 & -0.402 & $3.6 \times 10^{19}$ \\
\hline $\mathrm{Bi}, \mathrm{BaSe}, \mathrm{Bi}_{2} \mathrm{O}_{2} \mathrm{Se}, \mathrm{Ba}_{2} \mathrm{Bi}_{4} \mathrm{O}_{8}$ & -4.284 & 0.0 & -0.581 & -2.086 & -0.254 & $8.02 \times 10^{19}$ \\
\hline $\mathrm{Bi}, \mathrm{Bi}_{2} \mathrm{Se}_{3}, \mathrm{BaSe}, \mathrm{Bi}_{2} \mathrm{O}_{2} \mathrm{Se}$ & -4.286 & 0.0 & -0.582 & -2.087 & -0.252 & $8 \times 10^{19}$ \\
\hline $\mathrm{Bi}, \mathrm{Bi}_{2} \mathrm{Se}_{3}, \mathrm{BaSe}, \mathrm{BaCu}_{2} \mathrm{Se}_{2}$ & -4.286 & 0.0 & -0.553 & -2.116 & -0.252 & $7.29 \times 10^{19}$ \\
\hline
\end{tabular}


Table S7: Chemical potentials $\Delta \mu_{\mathrm{i}}$ (in eV) in all phase regions of the quinary Bi-Cu-Se-O-Ba phase space that are in equilibrium with $\mathrm{BiCuSeO}$. The corresponding charge carrier concentration in each phase region, as determined by charge neutrality at the typical synthesis temperature of $973 \mathrm{~K}$, is listed. 


\section{Phase Equilibriua of Li-Doped BiCuSeO}

\begin{tabular}{|c|c|c|c|c|c|c|}
\hline Equilibrium Phases & $\Delta \mu_{\mathrm{Bi}}$ & $\Delta \mu_{\mathrm{Cu}}$ & $\Delta \mu_{\mathrm{Li}}$ & $\Delta \mu_{\mathrm{O}}$ & $\Delta \mu_{\mathrm{Se}}$ & $p-n\left(\mathrm{~cm}^{-3}\right)$ \\
\hline $\mathrm{Se}, \mathrm{Cu}_{3} \mathrm{Se}_{2}, \mathrm{Bi}_{2} \mathrm{Se}_{3}, \mathrm{Bi}_{8} \mathrm{Li}_{24} \mathrm{O}_{24}$ & -0.378 & -0.62 & -2.217 & -1.923 & 0.0 & $1.12 \times 10^{20}$ \\
\hline $\mathrm{Se}, \mathrm{Bi}_{2} \mathrm{O}_{2} \mathrm{Se}, \mathrm{Bi}_{2} \mathrm{O}_{3}, \mathrm{BiLiO}_{2}$ & -0.603 & -0.708 & -2.509 & -1.61 & 0.0 & $1.44 \times 10^{20}$ \\
\hline $\mathrm{Se}, \mathrm{Bi}_{2} \mathrm{O}_{2} \mathrm{Se}, \mathrm{BiLiO}_{2}, \mathrm{Bi}_{8} \mathrm{Li}_{24} \mathrm{O}_{24}$ & -0.438 & -0.708 & -2.345 & -1.775 & 0.0 & $1.22 \times 10^{20}$ \\
\hline $\mathrm{Se}, \mathrm{Bi}_{2} \mathrm{O}_{2} \mathrm{Se}, \mathrm{Bi}_{2} \mathrm{Se}_{3}, \mathrm{Bi}_{8} \mathrm{Li}_{24} \mathrm{O}_{24}$ & -0.378 & -0.708 & -2.305 & -1.835 & 0.0 & $1.09 \times 10^{20}$ \\
\hline $\mathrm{Se}, \mathrm{Li}_{4} \mathrm{O}_{5} \mathrm{Se}, \mathrm{Cu}_{3} \mathrm{Se}_{2}, \mathrm{Bi}_{8} \mathrm{Li}_{24} \mathrm{O}_{24}$ & -0.609 & -0.62 & -2.372 & -1.691 & 0.0 & $1.75 \times 10^{20}$ \\
\hline $\mathrm{Se}, \mathrm{Li}_{4} \mathrm{O}_{5} \mathrm{Se}, \mathrm{Cu}_{3} \mathrm{Se}_{2}, \mathrm{Bi}_{2} \mathrm{O}_{3}$ & -0.865 & -0.62 & -2.691 & -1.435 & 0.0 & $1.48 \times 10^{20}$ \\
\hline $\mathrm{Se}, \mathrm{Li}_{4} \mathrm{O}_{5} \mathrm{Se}, \mathrm{BiLiO}_{2}, \mathrm{Bi}_{8} \mathrm{Li}_{24} \mathrm{O}_{24}$ & -0.594 & -0.655 & -2.397 & -1.671 & 0.0 & $1.57 \times 10^{20}$ \\
\hline $\mathrm{Se}, \mathrm{Li}_{4} \mathrm{O}_{5} \mathrm{Se}, \mathrm{Bi}_{2} \mathrm{O}_{3}, \mathrm{BiLiO}_{2}$ & -0.676 & -0.683 & -2.534 & -1.561 & 0.0 & $1.48 \times 10^{20}$ \\
\hline $\mathrm{Bi}, \mathrm{Bi}_{2} \mathrm{O}_{2} \mathrm{Se}, \mathrm{Bi}_{2} \mathrm{Se}_{3}, \mathrm{Bi}_{8} \mathrm{Li}_{24} \mathrm{O}_{24}$ & 0.0 & -0.582 & -2.179 & -2.087 & -0.252 & $4.61 \times 10^{19}$ \\
\hline $\mathrm{Bi}, \mathrm{BiLiO}_{2}, \mathrm{Cu}_{8} \mathrm{Li}_{8} \mathrm{O}_{8}, \mathrm{Bi}_{8} \mathrm{Li}_{24} \mathrm{O}_{24}$ & 0.0 & -0.329 & -2.199 & -2.067 & -0.525 & $2.62 \times 10^{19}$ \\
\hline $\mathrm{Bi}, \mathrm{Bi}_{2} \mathrm{O}_{2} \mathrm{Se}, \mathrm{BiLiO}_{2}, \mathrm{Bi}_{8} \mathrm{Li}_{24} \mathrm{O}_{24}$ & 0.0 & -0.562 & -2.199 & -2.067 & -0.292 & $4.48 \times 10^{19}$ \\
\hline $\mathrm{Bi}, \mathrm{Bi}_{2} \mathrm{O}_{2} \mathrm{Se}, \mathrm{Bi}_{2} \mathrm{O}_{3}, \mathrm{BiLiO}_{2}$ & 0.0 & -0.507 & -2.309 & -2.012 & -0.402 & $3.57 \times 10^{19}$ \\
\hline $\mathrm{Bi}, \mathrm{Bi}_{2} \mathrm{O}_{3}, \mathrm{BiLiO}_{2}, \mathrm{Cu}_{8} \mathrm{Li}_{8} \mathrm{O}_{8}$ & 0.0 & -0.274 & -2.309 & -2.012 & -0.634 & $1.53 \times 10^{19}$ \\
\hline $\mathrm{Bi}, \mathrm{Cu}_{2} \mathrm{O}, \mathrm{Bi}_{2} \mathrm{O}_{3}, \mathrm{Cu}_{8} \mathrm{Li}_{8} \mathrm{O}_{8}$ & 0.0 & -0.244 & -2.338 & -2.012 & -0.664 & $1.28 \times 10^{19}$ \\
\hline $\mathrm{Bi}, \mathrm{Cu}_{2} \mathrm{Se}, \mathrm{Cu}_{2} \mathrm{O}, \mathrm{Cu}_{8} \mathrm{Li}_{8} \mathrm{O}_{8}$ & 0.0 & -0.223 & -2.317 & -2.054 & -0.643 & $1.41 \times 10^{19}$ \\
\hline $\mathrm{Bi}, \mathrm{Cu}_{3} \mathrm{Se}_{2}, \mathrm{Bi}_{2} \mathrm{Se}_{3}, \mathrm{Bi}_{8} \mathrm{Li}_{24} \mathrm{O}_{24}$ & 0.0 & -0.452 & -2.049 & -2.216 & -0.252 & $4.26 \times 10^{19}$ \\
\hline $\mathrm{Bi}, \mathrm{Cu}_{2} \mathrm{Se}, \mathrm{Cu}_{3} \mathrm{Se}_{2}, \mathrm{Cu}_{8} \mathrm{Li}_{8} \mathrm{O}_{8}$ & 0.0 & -0.318 & -2.127 & -2.149 & -0.453 & $3.45 \times 10^{19}$ \\
\hline $\mathrm{Bi}, \mathrm{Cu}_{3} \mathrm{Se}_{2}, \mathrm{Cu}_{8} \mathrm{Li}_{8} \mathrm{O}_{8}, \mathrm{Bi}_{8} \mathrm{Li}_{24} \mathrm{O}_{24}$ & 0.0 & -0.329 & -2.111 & -2.155 & -0.437 & $3.66 \times 10^{19}$ \\
\hline $\mathrm{Cu}_{3} \mathrm{Se}_{2}, \mathrm{BiLiO}_{2}, \mathrm{Cu}_{8} \mathrm{Li}_{8} \mathrm{O}_{8}, \mathrm{Bi}_{8} \mathrm{Li}_{24} \mathrm{O}_{24}$ & -0.527 & -0.505 & -2.375 & -1.715 & -0.173 & $1.23 \times 10^{20}$ \\
\hline $\mathrm{Cu}_{3} \mathrm{Se}_{2}, \mathrm{Bi}_{2} \mathrm{O}_{3}, \mathrm{BiLiO}_{2}, \mathrm{Cu}_{8} \mathrm{Li}_{8} \mathrm{O}_{8}$ & -0.692 & -0.505 & -2.539 & -1.55 & -0.173 & $1.25 \times 10^{20}$ \\
\hline $\mathrm{Cu}_{2} \mathrm{O}, \mathrm{Cu}_{3} \mathrm{Se}_{2}, \mathrm{Bi}_{2} \mathrm{O}_{3}, \mathrm{Cu}_{8} \mathrm{Li}_{8} \mathrm{O}_{8}$ & -0.603 & -0.445 & -2.539 & -1.61 & -0.262 & $8.63 \times 10^{19}$ \\
\hline $\mathrm{Li}_{4} \mathrm{O}_{5} \mathrm{Se}, \mathrm{Cu}_{3} \mathrm{Se}_{2}, \mathrm{Bi}_{2} \mathrm{O}_{3}, \mathrm{BiLiO}_{2}$ & -0.739 & -0.536 & -2.555 & -1.519 & -0.126 & $1.43 \times 10^{20}$ \\
\hline $\mathrm{Li}_{4} \mathrm{O}_{5} \mathrm{Se}, \mathrm{Cu}_{3} \mathrm{Se}_{2}, \mathrm{BiLiO}_{2}, \mathrm{Bi}_{8} \mathrm{Li}_{24} \mathrm{O}_{24}$ & -0.63 & -0.573 & -2.409 & -1.647 & -0.071 & $1.65 \times 10^{20}$ \\
\hline $\mathrm{Cu}_{2} \mathrm{Se}, \mathrm{Cu}_{2} \mathrm{O}, \mathrm{Cu}_{3} \mathrm{Se}_{2}, \mathrm{Cu}_{8} \mathrm{Li}_{8} \mathrm{O}_{8}$ & -0.285 & -0.318 & -2.412 & -1.864 & -0.453 & $3.66 \times 10^{19}$ \\
\hline
\end{tabular}

Table S8: Chemical potentials $\Delta \mu_{\mathrm{i}}$ (in eV) in all phase regions of the quinary Bi-Cu-Se-O-Li phase space that are in equilibrium with $\mathrm{BiCuSeO}$. The corresponding charge carrier concentration in each phase region, as determined by charge neutrality at the typical synthesis temperature of $973 \mathrm{~K}$, is listed. 


\section{Phase Equilibriua of Zn-Doped BiCuSeO}

\begin{tabular}{|c|c|c|c|c|c|c|}
\hline Equilibrium Phases & $\Delta \mu_{\mathrm{Bi}}$ & $\Delta \mu_{\mathrm{Cu}}$ & $\Delta \mu_{\mathrm{O}}$ & $\Delta \mu_{\mathrm{Se}}$ & $\Delta \mu_{\mathrm{Zn}}$ & $p-n\left(\mathrm{~cm}^{-3}\right)$ \\
\hline $\mathrm{Bi}, \mathrm{Bi}_{2} \mathrm{O}_{2} \mathrm{Se}, \mathrm{Bi}_{2} \mathrm{Se}_{3}, \mathrm{SeZn}$ & 0.0 & -0.582 & -2.087 & -0.252 & -1.496 & 6.54 \\
\hline $\mathrm{Bi}, \mathrm{Bi}_{2} \mathrm{O}_{2} \mathrm{Se}, \mathrm{SeZn}, \mathrm{OZn}$ & 0.0 & -0.579 & -2.084 & -0.256 & -1.492 & $6.37 \times 10^{18}$ \\
\hline $\mathrm{Bi}, \mathrm{Cu}_{2} \mathrm{Se}, \mathrm{Cu}_{2} \mathrm{O}, \mathrm{OZn}$ & 0.0 & -0.223 & -2.054 & -0.643 & -1.522 & $4.3 \times 10^{18}$ \\
\hline $\mathrm{Bi}, \mathrm{Cu}_{2} \mathrm{O}, \mathrm{Bi}_{2} \mathrm{O}_{3}, \mathrm{OZn}$ & 0.0 & -0.244 & -2.012 & -0.664 & -1.564 & $4.94 \times 10^{18}$ \\
\hline $\mathrm{Bi}, \mathrm{Bi}_{2} \mathrm{O}_{2} \mathrm{Se}, \mathrm{Bi}_{2} \mathrm{O}_{3}, \mathrm{OZn}$ & 0.0 & -0.507 & -2.012 & -0.402 & -1.564 & $9.63 \times 10^{18}$ \\
\hline $\mathrm{Bi}, \mathrm{Bi}_{2} \mathrm{Se}_{3}, \mathrm{Cu}_{3} \mathrm{Se}_{2}, \mathrm{SeZn}$ & 0.0 & -0.452 & -2.216 & -0.252 & -1.496 & $6.37 \times 10^{18}$ \\
\hline $\mathrm{Bi}, \mathrm{Cu}_{3} \mathrm{Se}_{2}, \mathrm{SeZn}, \mathrm{OZn}$ & 0.0 & -0.384 & -2.182 & -0.354 & -1.394 & $3.33 \times 10^{18}$ \\
\hline $\mathrm{Bi}, \mathrm{Cu}_{2} \mathrm{Se}, \mathrm{Cu}_{3} \mathrm{Se}_{2}, \mathrm{OZn}$ & 0.0 & -0.318 & -2.149 & -0.453 & -1.427 & $3.99 \times 10^{18}$ \\
\hline $\mathrm{Cu}_{2} \mathrm{Se}, \mathrm{Cu}_{2} \mathrm{O}, \mathrm{Cu}_{3} \mathrm{Se}_{2}, \mathrm{OZn}$ & -0.285 & -0.318 & -1.864 & -0.453 & -1.712 & $1.04 \times 10^{19}$ \\
\hline $\mathrm{Cu}_{2} \mathrm{O}, \mathrm{Cu}_{3} \mathrm{Se}_{2}, \mathrm{Bi}_{2} \mathrm{O}_{3}, \mathrm{OZn}$ & -0.603 & -0.445 & -1.61 & -0.262 & -1.966 & $2.55 \times 10^{19}$ \\
\hline $\mathrm{Se}, \mathrm{Cu}_{3} \mathrm{Se}_{2}, \mathrm{Bi}_{2} \mathrm{O}_{3}, \mathrm{OZn}$ & -0.865 & -0.62 & -1.435 & 0.0 & -2.141 & $7.29 \times 10^{19}$ \\
\hline $\mathrm{Se}, \mathrm{Bi}_{2} \mathrm{O}_{2} \mathrm{Se}, \mathrm{Bi}_{2} \mathrm{Se}_{3}, \mathrm{SeZn}$ & -0.378 & -0.708 & -1.835 & 0.0 & -1.748 & $2.89 \times 10^{19}$ \\
\hline $\mathrm{Se}, \mathrm{Bi}_{2} \mathrm{O}_{2} \mathrm{Se}, \mathrm{SeZn}, \mathrm{OZn}$ & -0.385 & -0.708 & -1.828 & 0.0 & -1.748 & $2.89 \times 10^{19}$ \\
\hline $\mathrm{Se}, \mathrm{Bi}_{2} \mathrm{O}_{2} \mathrm{Se}, \mathrm{Bi}_{2} \mathrm{O}_{3}, \mathrm{OZn}$ & -0.603 & -0.708 & -1.61 & 0.0 & -1.966 & $8.07 \times 10^{19}$ \\
\hline $\mathrm{Se}, \mathrm{Bi}_{2} \mathrm{Se}_{3}, \mathrm{Cu}_{3} \mathrm{Se}_{2}, \mathrm{SeZn}$ & -0.378 & -0.62 & -1.923 & 0.0 & -1.748 & $2.76 \times 10^{19}$ \\
\hline $\mathrm{Se}, \mathrm{Cu}_{3} \mathrm{Se}_{2}, \mathrm{SeZn}, \mathrm{OZn}$ & -0.472 & -0.62 & -1.828 & 0.0 & -1.748 & $2.77 \times 10^{19}$ \\
\hline
\end{tabular}

Table S9: Chemical potentials $\Delta \mu_{\mathrm{i}}$ (in eV) in all phase regions of the quinary Bi-Cu-Se-O-Zn phase space that are in equilibrium with $\mathrm{BiCuSeO}$. The corresponding charge carrier concentration in each phase region, as determined by charge neutrality at the typical synthesis temperature of $973 \mathrm{~K}$, is listed. 


\section{Phase Equilibriua of Al-Doped BiCuSeO}

\begin{tabular}{|c|c|c|c|c|c|c|}
\hline Equilibrium Phases & $\Delta \mu_{\mathrm{Al}}$ & $\Delta \mu_{\mathrm{Bi}}$ & $\Delta \mu_{\mathrm{Cu}}$ & $\Delta \mu_{\mathrm{O}}$ & $\Delta \mu_{\mathrm{Se}}$ & $p-n\left(\mathrm{~cm}^{-3}\right)$ \\
\hline Se, $\mathrm{Al}_{2} \mathrm{O}_{3}, \mathrm{Bi}_{2} \mathrm{Se}_{3}, \mathrm{Cu}_{3} \mathrm{Se}_{2}$ & -5.916 & -0.378 & -0.62 & -1.923 & 0.0 & $7.36 \times 10^{19}$ \\
\hline $\mathrm{Se}, \mathrm{Bi}_{2} \mathrm{O}_{2} \mathrm{Se}, \mathrm{Bi}_{2} \mathrm{O}_{3}, \mathrm{Al}_{4} \mathrm{Bi}_{2} \mathrm{O}_{9}$ & -6.484 & -0.602 & -0.708 & -1.61 & 0.0 & $1.26 \times 10^{20}$ \\
\hline $\mathrm{Se}, \mathrm{Bi}_{2} \mathrm{O}_{2} \mathrm{Se}, \mathrm{Bi}_{2} \mathrm{Se}_{3}, \mathrm{Al}_{4} \mathrm{Bi}_{2} \mathrm{O}_{9}$ & -6.09 & -0.378 & -0.708 & -1.835 & 0.0 & $1.25 \times 10^{20}$ \\
\hline $\mathrm{Se}, \mathrm{Al}_{2} \mathrm{O}_{3}, \mathrm{Bi}_{2} \mathrm{Se}_{3}, \mathrm{Al}_{4} \mathrm{Bi}_{2} \mathrm{O}_{9}$ & -5.962 & -0.378 & -0.651 & -1.892 & 0.0 & $8.88 \times 10^{19}$ \\
\hline $\mathrm{Se}, \mathrm{Al}_{2} \mathrm{O}_{3}, \mathrm{Cu}_{3} \mathrm{Se}_{2}, \mathrm{Al}_{4} \mathrm{Bi}_{2} \mathrm{O}_{9}$ & -6.055 & -0.47 & -0.62 & -1.83 & 0.0 & $7.46 \times 10^{19}$ \\
\hline $\mathrm{Se}, \mathrm{Cu}_{3} \mathrm{Se}_{2}, \mathrm{Bi}_{2} \mathrm{O}_{3}, \mathrm{Al}_{4} \mathrm{Bi}_{2} \mathrm{O}_{9}$ & -6.746 & -0.865 & -0.62 & -1.435 & 0.0 & $7.5 \times 10^{19}$ \\
\hline $\mathrm{Cu}_{2} \mathrm{O}, \mathrm{Cu}_{3} \mathrm{Se}_{2}, \mathrm{AlCuO}_{2}, \mathrm{Bi}_{2} \mathrm{O}_{3}$ & -6.523 & -0.603 & -0.445 & -1.61 & -0.262 & $2.61 \times 10^{19}$ \\
\hline $\mathrm{Cu}_{3} \mathrm{Se}_{2}, \mathrm{AlCuO}_{2}, \mathrm{Bi}_{2} \mathrm{O}_{3}, \mathrm{Al}_{4} \mathrm{Bi}_{2} \mathrm{O}_{9}$ & -6.602 & -0.721 & -0.524 & -1.531 & -0.145 & $4.22 \times 10^{19}$ \\
\hline $\mathrm{Al}_{2} \mathrm{O}_{3}, \mathrm{Cu}_{3} \mathrm{Se}_{2}, \mathrm{AlCuO}_{2}, \mathrm{Al}_{4} \mathrm{Bi}_{2} \mathrm{O}_{9}$ & -5.614 & -0.029 & -0.326 & -2.124 & -0.441 & $1.17 \times 10^{19}$ \\
\hline $\mathrm{Cu}_{2} \mathrm{Se}, \mathrm{Cu}_{2} \mathrm{O}, \mathrm{Cu}_{3} \mathrm{Se}_{2}, \mathrm{AlCuO}_{2}$ & -6.142 & -0.285 & -0.318 & -1.864 & -0.453 & $1.13 \times 10^{19}$ \\
\hline $\mathrm{Cu}_{2} \mathrm{Se}, \mathrm{Al}_{2} \mathrm{O}_{3}, \mathrm{Cu}_{3} \mathrm{Se}_{2}, \mathrm{AlCuO}_{2}$ & -5.59 & -0.009 & -0.318 & -2.14 & -0.453 & $1.1 \times 10^{19}$ \\
\hline $\mathrm{Bi}, \mathrm{Cu}_{2} \mathrm{Se}, \mathrm{Al}_{2} \mathrm{O}_{3}, \mathrm{Cu}_{3} \mathrm{Se}_{2}$ & -5.576 & 0.0 & -0.318 & -2.149 & -0.453 & $1.1 \times 10^{19}$ \\
\hline $\mathrm{Bi}, \mathrm{Al}_{2} \mathrm{O}_{3}, \mathrm{Bi}_{2} \mathrm{Se}_{3}, \mathrm{Cu}_{3} \mathrm{Se}_{2}$ & -5.476 & 0.0 & -0.452 & -2.216 & -0.252 & $2.34 \times 10^{19}$ \\
\hline $\mathrm{Bi}, \mathrm{Cu}_{2} \mathrm{Se}, \mathrm{Cu}_{2} \mathrm{O}, \mathrm{AlCuO}_{2}$ & -5.857 & 0.0 & -0.223 & -2.054 & -0.643 & $5.11 \times 10^{18}$ \\
\hline $\mathrm{Bi}, \mathrm{Cu}_{2} \mathrm{Se}, \mathrm{Al}_{2} \mathrm{O}_{3}, \mathrm{AlCuO}_{2}$ & -5.581 & 0.0 & -0.315 & -2.146 & -0.459 & $1.08 \times 10^{19}$ \\
\hline $\mathrm{Bi}, \mathrm{Al}_{2} \mathrm{O}_{3}, \mathrm{AlCuO}_{2}, \mathrm{Al}_{4} \mathrm{Bi}_{2} \mathrm{O}_{9}$ & -5.585 & 0.0 & -0.316 & -2.143 & -0.46 & $1.08 \times 10^{19}$ \\
\hline $\mathrm{Bi}, \mathrm{AlCuO}_{2}, \mathrm{Bi}_{2} \mathrm{O}_{3}, \mathrm{Al}_{4} \mathrm{Bi}_{2} \mathrm{O}_{9}$ & -5.881 & 0.0 & -0.283 & -2.012 & -0.625 & $7.59 \times 10^{18}$ \\
\hline $\mathrm{Bi}, \mathrm{Cu}_{2} \mathrm{O}, \mathrm{AlCuO}_{2}, \mathrm{Bi}_{2} \mathrm{O}_{3}$ & -5.92 & 0.0 & -0.244 & -2.012 & -0.664 & $5.61 \times 10^{18}$ \\
\hline $\mathrm{Bi}, \mathrm{Bi}_{2} \mathrm{O}_{2} \mathrm{Se}, \mathrm{Bi}_{2} \mathrm{O}_{3}, \mathrm{Al}_{4} \mathrm{Bi}_{2} \mathrm{O}_{9}$ & -5.881 & 0.0 & -0.507 & -2.012 & -0.402 & $3.45 \times 10^{19}$ \\
\hline $\mathrm{Bi}, \mathrm{Bi}_{2} \mathrm{O}_{2} \mathrm{Se}, \mathrm{Bi}_{2} \mathrm{Se}_{3}, \mathrm{Al}_{4} \mathrm{Bi}_{2} \mathrm{O}_{9}$ & -5.712 & 0.0 & -0.582 & -2.087 & -0.252 & $5.39 \times 10^{19}$ \\
\hline $\mathrm{Bi}, \mathrm{Al}_{2} \mathrm{O}_{3}, \mathrm{Bi}_{2} \mathrm{Se}_{3}, \mathrm{Al}_{4} \mathrm{Bi}_{2} \mathrm{O}_{9}$ & -5.585 & 0.0 & -0.525 & -2.143 & -0.252 & $3.77 \times 10^{19}$ \\
\hline
\end{tabular}

Table S10: Chemical potentials $\Delta \mu_{\mathrm{i}}$ (in eV) in all phase regions of the quinary Bi-Cu-Se-O-Al phase space that are in equilibrium with $\mathrm{BiCuSeO}$. The corresponding charge carrier concentration in each phase region, as determined by charge neutrality at the typical synthesis temperature of $973 \mathrm{~K}$, is listed. 


\section{Phase Equilibriua of Ga-Doped BiCuSeO}

\begin{tabular}{|c|c|c|c|c|c|c|}
\hline Equilibrium Phases & $\Delta \mu_{\mathrm{Bi}}$ & $\Delta \mu_{\mathrm{Cu}}$ & $\Delta \mu_{\mathrm{Ga}}$ & $\Delta \mu_{\mathrm{O}}$ & $\Delta \mu_{\mathrm{Se}}$ & $p-n\left(\mathrm{~cm}^{-3}\right)$ \\
\hline $\mathrm{Se}, \mathrm{Cu}_{3} \mathrm{Se}_{2}, \mathrm{Ga}_{2} \mathrm{O}_{3}, \mathrm{Bi}_{2} \mathrm{Se}_{3}$ & -0.378 & -0.62 & -2.811 & -1.923 & 0.0 & $7.36 \times 10^{19}$ \\
\hline $\mathrm{Se}, \mathrm{Bi}_{2} \mathrm{O}_{2} \mathrm{Se}, \mathrm{Bi}_{2} \mathrm{Ga}_{4} \mathrm{O}_{9}, \mathrm{Bi}_{2} \mathrm{O}_{3}$ & -0.602 & -0.708 & -3.341 & -1.61 & 0.0 & $1.26 \times 10^{20}$ \\
\hline $\mathrm{Se}, \mathrm{Bi}_{2} \mathrm{Ga}_{4} \mathrm{O}_{9}, \mathrm{Ga}_{2} \mathrm{O}_{3}, \mathrm{Bi}_{2} \mathrm{Se}_{3}$ & -0.378 & -0.701 & -2.933 & -1.842 & 0.0 & $1.19 \times 10^{20}$ \\
\hline $\mathrm{Se}, \mathrm{Bi}_{2} \mathrm{O}_{2} \mathrm{Se}, \mathrm{Bi}_{2} \mathrm{Ga}_{4} \mathrm{O}_{9}, \mathrm{Bi}_{2} \mathrm{Se}_{3}$ & -0.378 & -0.708 & -2.948 & -1.835 & 0.0 & $1.24 \times 10^{20}$ \\
\hline $\mathrm{Se}, \mathrm{Bi}_{2} \mathrm{Ga}_{4} \mathrm{O}_{9}, \mathrm{Cu}_{3} \mathrm{Se}_{2}, \mathrm{Ga}_{2} \mathrm{O}_{3}$ & -0.62 & -0.62 & -3.175 & -1.68 & 0.0 & $7.48 \times 10^{19}$ \\
\hline $\mathrm{Se}, \mathrm{Bi}_{2} \mathrm{Ga}_{4} \mathrm{O}_{9}, \mathrm{Cu}_{3} \mathrm{Se}_{2}, \mathrm{Bi}_{2} \mathrm{O}_{3}$ & -0.865 & -0.62 & -3.604 & -1.435 & 0.0 & $7.5 \times 10^{19}$ \\
\hline $\mathrm{Bi}, \mathrm{Cu}_{2} \mathrm{O}, \mathrm{CuGaO}_{2}, \mathrm{Bi}_{2} \mathrm{O}_{3}$ & 0.0 & -0.244 & -2.754 & -2.012 & -0.664 & $5.61 \times 10^{18}$ \\
\hline $\mathrm{Bi}, \mathrm{Bi}_{2} \mathrm{O}_{2} \mathrm{Se}, \mathrm{Bi}_{2} \mathrm{Ga}_{4} \mathrm{O}_{9}, \mathrm{Bi}_{2} \mathrm{Se}_{3}$ & 0.0 & -0.582 & -2.57 & -2.087 & -0.252 & $5.37 \times 10^{19}$ \\
\hline $\mathrm{Bi}, \mathrm{Bi}_{2} \mathrm{Ga}_{4} \mathrm{O}_{9}, \mathrm{Ga}_{2} \mathrm{O}_{3}, \mathrm{Bi}_{2} \mathrm{Se}_{3}$ & 0.0 & -0.575 & -2.555 & -2.093 & -0.252 & $5.14 \times 10^{19}$ \\
\hline $\mathrm{Bi}, \mathrm{Bi}_{2} \mathrm{O}_{2} \mathrm{Se}, \mathrm{Bi}_{2} \mathrm{Ga}_{4} \mathrm{O}_{9}, \mathrm{Bi}_{2} \mathrm{O}_{3}$ & 0.0 & -0.507 & -2.739 & -2.012 & -0.402 & $3.45 \times 10^{19}$ \\
\hline $\mathrm{Bi}, \mathrm{CuGaO}_{2}, \mathrm{Bi}_{2} \mathrm{Ga}_{4} \mathrm{O}_{9}, \mathrm{Ga}_{2} \mathrm{O}_{3}$ & 0.0 & -0.28 & -2.555 & -2.093 & -0.546 & $8.27 \times 10^{18}$ \\
\hline $\mathrm{Bi}, \mathrm{CuGaO}_{2}, \mathrm{Bi}_{2} \mathrm{Ga}_{4} \mathrm{O}_{9}, \mathrm{Bi}_{2} \mathrm{O}_{3}$ & 0.0 & -0.26 & -2.739 & -2.012 & -0.648 & $6.37 \times 10^{18}$ \\
\hline $\mathrm{Bi}, \mathrm{Cu}_{2} \mathrm{Se}, \mathrm{CuGaO}_{2}, \mathrm{Ga}_{2} \mathrm{O}_{3}$ & 0.0 & -0.274 & -2.537 & -2.105 & -0.54 & $8 \times 10^{18}$ \\
\hline $\mathrm{Bi}, \mathrm{Cu}_{2} \mathrm{Se}, \mathrm{Cu}_{2} \mathrm{O}, \mathrm{CuGaO}_{2}$ & 0.0 & -0.223 & -2.691 & -2.054 & -0.643 & $5.11 \times 10^{18}$ \\
\hline $\mathrm{Bi}, \mathrm{Cu}_{3} \mathrm{Se}_{2}, \mathrm{Ga}_{2} \mathrm{O}_{3}, \mathrm{Bi}_{2} \mathrm{Se}_{3}$ & 0.0 & -0.452 & -2.371 & -2.216 & -0.252 & $2.33 \times 10^{19}$ \\
\hline $\mathrm{Bi}, \mathrm{Cu}_{2} \mathrm{Se}, \mathrm{Cu}_{3} \mathrm{Se}_{2}, \mathrm{Ga}_{2} \mathrm{O}_{3}$ & 0.0 & -0.318 & -2.471 & -2.149 & -0.453 & $1.1 \times 10^{19}$ \\
\hline $\mathrm{CuGaO}_{2}, \mathrm{Bi}_{2} \mathrm{Ga}_{4} \mathrm{O}_{9}, \mathrm{Cu}_{3} \mathrm{Se}_{2}, \mathrm{Ga}_{2} \mathrm{O}_{3}$ & -0.221 & -0.354 & -2.776 & -1.946 & -0.399 & $1.44 \times 10^{19}$ \\
\hline $\mathrm{CuGaO}_{2}, \mathrm{Bi}_{2} \mathrm{Ga}_{4} \mathrm{O}_{9}, \mathrm{Cu}_{3} \mathrm{Se}_{2}, \mathrm{Bi}_{2} \mathrm{O}_{3}$ & -0.65 & -0.477 & -3.389 & -1.578 & -0.215 & $3.17 \times 10^{19}$ \\
\hline $\mathrm{Cu}_{2} \mathrm{O}, \mathrm{CuGaO}_{2}, \mathrm{Cu}_{3} \mathrm{Se}_{2}, \mathrm{Bi}_{2} \mathrm{O}_{3}$ & -0.603 & -0.445 & -3.357 & -1.61 & -0.262 & $2.61 \times 10^{19}$ \\
\hline $\mathrm{Cu}_{2} \mathrm{Se}, \mathrm{Cu}_{2} \mathrm{O}, \mathrm{CuGaO}_{2}, \mathrm{Cu}_{3} \mathrm{Se}_{2}$ & -0.285 & -0.318 & -2.976 & -1.864 & -0.453 & $1.13 \times 10^{19}$ \\
\hline $\mathrm{Cu}_{2} \mathrm{Se}, \mathrm{CuGaO}_{2}, \mathrm{Cu}_{3} \mathrm{Se}_{2}, \mathrm{Ga}_{2} \mathrm{O}_{3}$ & -0.131 & -0.318 & -2.668 & -2.018 & -0.453 & $1.13 \times 10^{19}$ \\
\hline
\end{tabular}

Table S11: Chemical potentials $\Delta \mu_{\mathrm{i}}$ (in eV) in all phase regions of the quinary Bi-Cu-Se-O-Ga phase space that are in equilibrium with $\mathrm{BiCuSeO}$. The corresponding charge carrier concentration in each phase region, as determined by charge neutrality at the typical synthesis temperature of $973 \mathrm{~K}$, is listed. 


\section{Phase Equilibriua of In-Doped BiCuSeO}

\begin{tabular}{|c|c|c|c|c|c|c|}
\hline Equilibrium Phases & $\Delta \mu_{\mathrm{Bi}}$ & $\Delta \mu_{\mathrm{Cu}}$ & $\Delta \mu_{\text {In }}$ & $\Delta \mu_{\mathrm{O}}$ & $\Delta \mu_{\mathrm{Se}}$ & $p-n\left(\mathrm{~cm}^{-3}\right)$ \\
\hline $\mathrm{Se}, \mathrm{In}_{2} \mathrm{O}_{3}, \mathrm{Cu}_{3} \mathrm{Se}_{2}, \mathrm{CuInSe} \mathrm{I}_{2}$ & -0.379 & -0.62 & -1.896 & -1.921 & 0.0 & $7.34 \times 10^{19}$ \\
\hline $\mathrm{Se}, \mathrm{Cu}_{3} \mathrm{Se}_{2}, \mathrm{CuInSe}_{2}, \mathrm{Bi}_{2} \mathrm{Se}_{3}$ & -0.378 & -0.62 & -1.896 & -1.923 & 0.0 & $7.34 \times 10^{19}$ \\
\hline $\mathrm{Se}, \mathrm{In}_{2} \mathrm{O}_{3}, \mathrm{Bi}_{2} \mathrm{O}_{2} \mathrm{Se}, \mathrm{Bi}_{2} \mathrm{O}_{3}$ & -0.602 & -0.708 & -2.362 & -1.61 & 0.0 & $1.26 \times 10^{20}$ \\
\hline $\mathrm{Se}, \mathrm{In}_{2} \mathrm{O}_{3}, \mathrm{CuInSe}{ }_{2}, \mathrm{Bi}_{2} \mathrm{Se}_{3}$ & -0.378 & -0.621 & -1.895 & -1.922 & 0.0 & $7.39 \times 10^{19}$ \\
\hline $\mathrm{Se}, \mathrm{In}_{2} \mathrm{O}_{3}, \mathrm{Bi}_{2} \mathrm{O}_{2} \mathrm{Se}, \mathrm{Bi}_{2} \mathrm{Se}_{3}$ & -0.378 & -0.708 & -2.025 & -1.835 & 0.0 & $1.24 \times 10^{20}$ \\
\hline $\mathrm{Se}, \mathrm{In}_{2} \mathrm{O}_{3}, \mathrm{Cu}_{3} \mathrm{Se}_{2}, \mathrm{Bi}_{2} \mathrm{O}_{3}$ & -0.865 & -0.62 & -2.625 & -1.435 & 0.0 & $7.48 \times 10^{19}$ \\
\hline $\mathrm{Bi}, \mathrm{In}_{2} \mathrm{O}_{3}, \mathrm{Bi}_{2} \mathrm{O}_{2} \mathrm{Se}, \mathrm{Bi}_{2} \mathrm{Se}_{3}$ & 0.0 & -0.582 & -1.648 & -2.087 & -0.252 & $5.36 \times 10^{19}$ \\
\hline $\mathrm{Bi}, \mathrm{In}_{2} \mathrm{O}_{3}, \mathrm{CuInSe}{ }_{2}, \mathrm{Bi}_{2} \mathrm{Se}_{3}$ & 0.0 & -0.495 & -1.518 & -2.173 & -0.252 & $3.08 \times 10^{19}$ \\
\hline $\mathrm{Bi}, \mathrm{In}_{2} \mathrm{O}_{3}, \mathrm{Bi}_{2} \mathrm{O}_{2} \mathrm{Se}, \mathrm{Bi}_{2} \mathrm{O}_{3}$ & 0.0 & -0.507 & -1.76 & -2.012 & -0.402 & $3.45 \times 10^{19}$ \\
\hline $\mathrm{Bi}, \mathrm{Cu}_{2} \mathrm{Se}, \mathrm{In}_{2} \mathrm{O}_{3}, \mathrm{CuInO} \mathrm{O}_{2}$ & 0.0 & -0.223 & -1.696 & -2.054 & -0.642 & $5.13 \times 10^{18}$ \\
\hline $\mathrm{Bi}, \mathrm{Cu}_{2} \mathrm{Se}, \mathrm{Cu}_{2} \mathrm{O}, \mathrm{CuInO} \mathrm{O}_{2}$ & 0.0 & -0.223 & -1.697 & -2.054 & -0.643 & $5.11 \times 10^{18}$ \\
\hline $\mathrm{Bi}, \mathrm{Cu}_{2} \mathrm{O}, \mathrm{CuInO}_{2}, \mathrm{Bi}_{2} \mathrm{O}_{3}$ & 0.0 & -0.244 & -1.76 & -2.012 & -0.664 & $5.61 \times 10^{18}$ \\
\hline $\mathrm{Bi}, \mathrm{In}_{2} \mathrm{O}_{3}, \mathrm{CuInO}_{2}, \mathrm{Bi}_{2} \mathrm{O}_{3}$ & 0.0 & -0.245 & -1.76 & -2.012 & -0.664 & $5.65 \times 10^{18}$ \\
\hline $\mathrm{Bi}, \mathrm{Cu}_{3} \mathrm{Se}_{2}, \mathrm{CuInSe}_{2}, \mathrm{Bi}_{2} \mathrm{Se}_{3}$ & 0.0 & -0.452 & -1.56 & -2.216 & -0.252 & $2.33 \times 10^{19}$ \\
\hline $\mathrm{Bi}, \mathrm{In}_{2} \mathrm{O}_{3}, \mathrm{Cu}_{3} \mathrm{Se}_{2}, \mathrm{CuInSe}_{2}$ & 0.0 & -0.413 & -1.482 & -2.197 & -0.31 & $1.91 \times 10^{19}$ \\
\hline $\mathrm{Bi}, \mathrm{Cu}_{2} \mathrm{Se}, \mathrm{In}_{2} \mathrm{O}_{3}, \mathrm{Cu}_{3} \mathrm{Se}_{2}$ & 0.0 & -0.318 & -1.554 & -2.149 & -0.453 & $1.1 \times 10^{19}$ \\
\hline $\mathrm{In}_{2} \mathrm{O}_{3}, \mathrm{CuInO}_{2}, \mathrm{Cu}_{3} \mathrm{Se}_{2}, \mathrm{Bi}_{2} \mathrm{O}_{3}$ & -0.604 & -0.446 & -2.364 & -1.609 & -0.261 & $2.62 \times 10^{19}$ \\
\hline $\mathrm{Cu}_{2} \mathrm{O}, \mathrm{CuInO}_{2}, \mathrm{Cu}_{3} \mathrm{Se}_{2}, \mathrm{Bi}_{2} \mathrm{O}_{3}$ & -0.603 & -0.445 & -2.363 & -1.61 & -0.262 & $2.6 \times 10^{19}$ \\
\hline $\mathrm{Cu}_{2} \mathrm{Se}, \mathrm{In}_{2} \mathrm{O}_{3}, \mathrm{CuInO}_{2}, \mathrm{Cu}_{3} \mathrm{Se}_{2}$ & -0.284 & -0.318 & -1.98 & -1.865 & -0.453 & $1.13 \times 10^{19}$ \\
\hline $\mathrm{Cu}_{2} \mathrm{Se}, \mathrm{Cu}_{2} \mathrm{O}, \mathrm{CuInO}_{2}, \mathrm{Cu}_{3} \mathrm{Se}_{2}$ & -0.285 & -0.318 & -1.982 & -1.864 & -0.453 & $1.13 \times 10^{19}$ \\
\hline
\end{tabular}

Table S12: Chemical potentials $\Delta \mu_{\mathrm{i}}$ (in $\mathrm{eV}$ ) in all phase regions of the quinary Bi-Cu-Se-O-In phase space that are in equilibrium with $\mathrm{BiCuSeO}$. The corresponding charge carrier concentration in each phase region, as determined by charge neutrality at the typical synthesis temperature of $973 \mathrm{~K}$, is listed. 


\section{Phase Equilibriua of Tl-Doped BiCuSeO}

\begin{tabular}{|c|c|c|c|c|c|c|}
\hline Equilibrium Phases & $\Delta \mu_{\mathrm{Bi}}$ & $\Delta \mu_{\mathrm{Cu}}$ & $\Delta \mu_{\mathrm{O}}$ & $\Delta \mu_{\mathrm{Se}}$ & $\Delta \mu_{\mathrm{Tl}}$ & $p-n\left(\mathrm{~cm}^{-3}\right)$ \\
\hline $\mathrm{Bi}, \mathrm{Bi}_{2} \mathrm{O}_{2} \mathrm{Se}, \mathrm{BiSe}_{2} \mathrm{Tl}, \mathrm{Bi}_{2} \mathrm{Se}_{3}$ & 0.0 & -0.582 & -2.087 & -0.252 & -0.659 & $5.39 \times 10^{19}$ \\
\hline $\mathrm{Bi}, \mathrm{BiSe}_{2} \mathrm{Tl}, \mathrm{Bi}_{2} \mathrm{O}_{3}, \mathrm{Se}_{12} \mathrm{Tl}_{20}$ & 0.0 & -0.41 & -2.012 & -0.498 & -0.166 & $1.85 \times 10^{19}$ \\
\hline $\mathrm{Bi}, \mathrm{Bi}_{2} \mathrm{O}_{2} \mathrm{Se}, \mathrm{BiSe}_{2} \mathrm{Tl}, \mathrm{Bi}_{2} \mathrm{O}_{3}$ & 0.0 & -0.507 & -2.012 & -0.402 & -0.359 & $3.45 \times 10^{19}$ \\
\hline $\mathrm{Bi}, \mathrm{BiSe}_{2} \mathrm{Tl}, \mathrm{Cu}_{3} \mathrm{Se}_{2}, \mathrm{Bi}_{2} \mathrm{Se}_{3}$ & 0.0 & -0.452 & -2.216 & -0.252 & -0.659 & $2.34 \times 10^{19}$ \\
\hline $\mathrm{Bi}, \mathrm{BiSe}_{2} \mathrm{Tl}, \mathrm{Se}_{12} \mathrm{Tl}_{20}, \mathrm{Cu}_{2} \mathrm{Se}_{2} \mathrm{Tl}$ & 0.0 & -0.399 & -2.023 & -0.498 & -0.166 & $1.74 \times 10^{19}$ \\
\hline $\mathrm{Bi}, \mathrm{Bi}_{2} \mathrm{O}_{3}, \mathrm{Se}_{12} \mathrm{Tl}_{20}, \mathrm{Cu}_{2} \mathrm{Se}_{2} \mathrm{Tl}$ & 0.0 & -0.372 & -2.012 & -0.537 & -0.142 & $1.43 \times 10^{19}$ \\
\hline $\mathrm{Bi}, \mathrm{Cu}_{2} \mathrm{O}, \mathrm{Bi}_{2} \mathrm{O}_{3}, \mathrm{Cu}_{2} \mathrm{Se}_{2} \mathrm{Tl}$ & 0.0 & -0.244 & -2.012 & -0.664 & -0.142 & $5.67 \times 10^{18}$ \\
\hline $\mathrm{Bi}, \mathrm{Cu}_{2} \mathrm{Se}, \mathrm{Cu}_{2} \mathrm{O}, \mathrm{Cu}_{2} \mathrm{Se}_{2} \mathrm{Tl}$ & 0.0 & -0.223 & -2.054 & -0.643 & -0.227 & $5.15 \times 10^{18}$ \\
\hline $\mathrm{Bi}, \mathrm{BiSe}_{2} \mathrm{Tl}, \mathrm{Cu}_{3} \mathrm{Se}_{2}, \mathrm{Cu}_{2} \mathrm{Se}_{2} \mathrm{Tl}$ & 0.0 & -0.399 & -2.189 & -0.332 & -0.498 & $1.78 \times 10^{19}$ \\
\hline $\mathrm{Bi}, \mathrm{Cu}_{2} \mathrm{Se}, \mathrm{Cu}_{3} \mathrm{Se}_{2}, \mathrm{Cu}_{2} \mathrm{Se}_{2} \mathrm{Tl}$ & 0.0 & -0.318 & -2.149 & -0.453 & -0.417 & $1.1 \times 10^{19}$ \\
\hline $\mathrm{BiSe}_{2} \mathrm{Tl}, \mathrm{Bi}_{2} \mathrm{O}_{3}, \mathrm{Se}_{12} \mathrm{Tl}_{20}, \mathrm{Cu}_{2} \mathrm{Se}_{2} \mathrm{Tl}$ & -0.097 & -0.447 & -1.947 & -0.429 & -0.207 & $2.44 \times 10^{19}$ \\
\hline $\mathrm{Cu}_{2} \mathrm{Se}, \mathrm{Cu}_{2} \mathrm{O}, \mathrm{Cu}_{3} \mathrm{Se}_{2}, \mathrm{Cu}_{2} \mathrm{Se}_{2} \mathrm{Tl}$ & -0.285 & -0.318 & -1.864 & -0.453 & -0.417 & $1.14 \times 10^{19}$ \\
\hline $\mathrm{Cu}_{2} \mathrm{O}, \mathrm{Cu}_{3} \mathrm{Se}_{2}, \mathrm{Bi}_{2} \mathrm{O}_{3}, \mathrm{Cu}_{2} \mathrm{Se}_{2} \mathrm{Tl}$ & -0.603 & -0.445 & -1.61 & -0.262 & -0.544 & $2.62 \times 10^{19}$ \\
\hline $\mathrm{Se}, \mathrm{Cu}_{3} \mathrm{Se}_{2}, \mathrm{Bi}_{2} \mathrm{O}_{3}, \mathrm{Cu}_{2} \mathrm{Se}_{2} \mathrm{Tl}$ & -0.865 & -0.62 & -1.435 & 0.0 & -0.719 & $7.53 \times 10^{19}$ \\
\hline $\mathrm{Se}, \mathrm{BiSe}_{2} \mathrm{Tl}, \mathrm{Bi}_{2} \mathrm{O}_{3}, \mathrm{Cu}_{2} \mathrm{Se}_{2} \mathrm{Tl}$ & -0.612 & -0.704 & -1.604 & 0.0 & -0.55 & $1.23 \times 10^{20}$ \\
\hline $\mathrm{Se}, \mathrm{Bi}_{2} \mathrm{O}_{2} \mathrm{Se}, \mathrm{BiSe}_{2} \mathrm{Tl}, \mathrm{Bi}_{2} \mathrm{Se}_{3}$ & -0.378 & -0.708 & -1.835 & 0.0 & -0.784 & $1.25 \times 10^{20}$ \\
\hline $\mathrm{Se}, \mathrm{Bi}_{2} \mathrm{O}_{2} \mathrm{Se}, \mathrm{BiSe}_{2} \mathrm{Tl}, \mathrm{Bi}_{2} \mathrm{O}_{3}$ & -0.602 & -0.708 & -1.61 & 0.0 & -0.56 & $1.26 \times 10^{20}$ \\
\hline $\mathrm{Se}, \mathrm{BiSe}_{2} \mathrm{Tl}, \mathrm{Cu}_{3} \mathrm{Se}_{2}, \mathrm{Bi}_{2} \mathrm{Se}_{3}$ & -0.378 & -0.62 & -1.923 & 0.0 & -0.784 & $7.36 \times 10^{19}$ \\
\hline $\mathrm{Se}, \mathrm{BiSe}_{2} \mathrm{Tl}, \mathrm{Cu}_{3} \mathrm{Se}_{2}, \mathrm{Cu}_{2} \mathrm{Se}_{2} \mathrm{Tl}$ & -0.443 & -0.62 & -1.857 & 0.0 & -0.719 & $7.43 \times 10^{19}$ \\
\hline
\end{tabular}

Table S13: Chemical potentials $\Delta \mu_{\mathrm{i}}$ (in eV) in all phase regions of the quinary Bi-Cu-Se-O-Tl phase space that are in equilibrium with $\mathrm{BiCuSeO}$. The corresponding charge carrier concentration in each phase region, as determined by charge neutrality at the typical synthesis temperature of $973 \mathrm{~K}$, is listed. 


\section{Phase Equilibriua of Si-Doped BiCuSeO}

\begin{tabular}{|c|c|c|c|c|c|c|}
\hline Equilibrium Phases & $\Delta \mu_{\mathrm{Bi}}$ & $\Delta \mu_{\mathrm{Cu}}$ & $\Delta \mu_{\mathrm{O}}$ & $\Delta \mu_{\mathrm{Se}}$ & $\Delta \mu_{\mathrm{Si}}$ & $p-n\left(\mathrm{~cm}^{-3}\right)$ \\
\hline $\mathrm{Bi}, \mathrm{Bi}_{4} \mathrm{O}_{12} \mathrm{Si}_{3}, \mathrm{Bi}_{2} \mathrm{Se}_{3}, \mathrm{O}_{2} \mathrm{Si}$ & 0.0 & -0.491 & -2.177 & -0.252 & -5.116 & $3.02 \times 10^{19}$ \\
\hline $\mathrm{Bi}, \mathrm{Bi}_{4} \mathrm{O}_{12} \mathrm{Si}_{3}, \mathrm{Bi}_{2} \mathrm{O}_{2} \mathrm{Se}, \mathrm{Bi}_{2} \mathrm{Se}_{3}$ & 0.0 & -0.582 & -2.087 & -0.252 & -5.477 & $5.39 \times 10^{19}$ \\
\hline $\mathrm{Bi}, \mathrm{Cu}_{2} \mathrm{O}, \mathrm{Bi}_{4} \mathrm{O}_{12} \mathrm{Si}_{3}, \mathrm{Bi}_{2} \mathrm{O}_{3}$ & 0.0 & -0.244 & -2.012 & -0.664 & -5.777 & $5.61 \times 10^{18}$ \\
\hline $\mathrm{Bi}, \mathrm{Bi}_{4} \mathrm{O}_{12} \mathrm{Si}_{3}, \mathrm{Bi}_{2} \mathrm{O}_{2} \mathrm{Se}, \mathrm{Bi}_{2} \mathrm{O}_{3}$ & 0.0 & -0.507 & -2.012 & -0.402 & -5.777 & $3.45 \times 10^{19}$ \\
\hline $\mathrm{Bi}, \mathrm{Cu}_{2} \mathrm{Se}, \mathrm{Cu}_{2} \mathrm{O}, \mathrm{Bi}_{4} \mathrm{O}_{12} \mathrm{Si}_{3}$ & 0.0 & -0.223 & -2.054 & -0.643 & -5.608 & $5.11 \times 10^{18}$ \\
\hline $\mathrm{Bi}, \mathrm{Cu}_{3} \mathrm{Se}_{2}, \mathrm{Bi}_{2} \mathrm{Se}_{3}, \mathrm{O}_{2} \mathrm{Si}$ & 0.0 & -0.452 & -2.216 & -0.252 & -5.038 & $2.34 \times 10^{19}$ \\
\hline $\mathrm{Bi}, \mathrm{Bi}_{4} \mathrm{O}_{12} \mathrm{Si}_{3}, \mathrm{Cu}_{3} \mathrm{Se}_{2}, \mathrm{O}_{2} \mathrm{Si}$ & 0.0 & -0.374 & -2.177 & -0.369 & -5.116 & $1.55 \times 10^{19}$ \\
\hline $\mathrm{Bi}, \mathrm{Cu}_{2} \mathrm{Se}, \mathrm{Bi}_{4} \mathrm{O}_{12} \mathrm{Si}_{3}, \mathrm{Cu}_{3} \mathrm{Se}_{2}$ & 0.0 & -0.318 & -2.149 & -0.453 & -5.228 & $1.1 \times 10^{19}$ \\
\hline $\mathrm{Bi}_{4} \mathrm{O}_{12} \mathrm{Si}_{3}, \mathrm{Cu}_{3} \mathrm{Se}_{2}, \mathrm{Bi}_{2} \mathrm{Se}_{3}, \mathrm{O}_{2} \mathrm{Si}$ & -0.352 & -0.609 & -1.942 & -0.017 & -5.586 & $6.87 \times 10^{19}$ \\
\hline $\mathrm{Cu}_{2} \mathrm{Se}, \mathrm{Cu}_{2} \mathrm{O}, \mathrm{Bi}_{4} \mathrm{O}_{12} \mathrm{Si}_{3}, \mathrm{Cu}_{3} \mathrm{Se}_{2}$ & -0.285 & -0.318 & -1.864 & -0.453 & -5.988 & $1.13 \times 10^{19}$ \\
\hline $\mathrm{Cu}_{2} \mathrm{O}, \mathrm{Bi}_{4} \mathrm{O}_{12} \mathrm{Si}_{3}, \mathrm{Cu}_{3} \mathrm{Se}_{2}, \mathrm{Bi}_{2} \mathrm{O}_{3}$ & -0.603 & -0.445 & -1.61 & -0.262 & -6.581 & $2.61 \times 10^{19}$ \\
\hline $\mathrm{Se}, \mathrm{Bi}_{4} \mathrm{O}_{12} \mathrm{Si}_{3}, \mathrm{Cu}_{3} \mathrm{Se}_{2}, \mathrm{Bi}_{2} \mathrm{O}_{3}$ & -0.865 & -0.62 & -1.435 & 0.0 & -6.931 & $7.5 \times 10^{19}$ \\
\hline $\mathrm{Se}, \mathrm{Bi}_{4} \mathrm{O}_{12} \mathrm{Si}_{3}, \mathrm{Cu}_{3} \mathrm{Se}_{2}, \mathrm{Bi}_{2} \mathrm{Se}_{3}$ & -0.378 & -0.62 & -1.923 & 0.0 & -5.63 & $7.36 \times 10^{19}$ \\
\hline $\mathrm{Se}, \mathrm{Bi}_{4} \mathrm{O}_{12} \mathrm{Si}_{3}, \mathrm{Bi}_{2} \mathrm{O}_{2} \mathrm{Se}, \mathrm{Bi}_{2} \mathrm{Se}_{3}$ & -0.378 & -0.708 & -1.835 & 0.0 & -5.981 & $1.25 \times 10^{20}$ \\
\hline $\mathrm{Se}, \mathrm{Bi}_{4} \mathrm{O}_{12} \mathrm{Si}_{3}, \mathrm{Bi}_{2} \mathrm{O}_{2} \mathrm{Se}, \mathrm{Bi}_{2} \mathrm{O}_{3}$ & -0.603 & -0.708 & -1.61 & 0.0 & -6.581 & $1.26 \times 10^{20}$ \\
\hline
\end{tabular}

Table S14: Chemical potentials $\Delta \mu_{\mathrm{i}}$ (in eV) in all phase regions of the quinary Bi-Cu-Se-O-Si phase space that are in equilibrium with $\mathrm{BiCuSeO}$. The corresponding charge carrier concentration in each phase region, as determined by charge neutrality at the typical synthesis temperature of $973 \mathrm{~K}$, is listed. 


\section{Phase Equilibriua of Ge-Doped BiCuSeO}

\begin{tabular}{|c|c|c|c|c|c|c|}
\hline Equilibrium Phases & $\Delta \mu_{\mathrm{Bi}}$ & $\Delta \mu_{\mathrm{Cu}}$ & $\Delta \mu_{\mathrm{Ge}}$ & $\Delta \mu_{\mathrm{O}}$ & $\Delta \mu_{\mathrm{Se}}$ & $p-n\left(\mathrm{~cm}^{-3}\right)$ \\
\hline $\mathrm{Se}, \mathrm{Bi}_{4} \mathrm{Ge}_{3} \mathrm{O}_{12}, \mathrm{Cu}_{3} \mathrm{Se}_{2}, \mathrm{Bi}_{2} \mathrm{Se}_{3}$ & -0.378 & -0.62 & -2.165 & -1.923 & 0.0 & $7.36 \times 10^{19}$ \\
\hline $\mathrm{Se}, \mathrm{Bi}_{12} \mathrm{GeO}_{20}, \mathrm{Bi}_{2} \mathrm{O}_{2} \mathrm{Se}, \mathrm{Bi}_{4} \mathrm{Ge}_{3} \mathrm{O}_{12}$ & -0.582 & -0.708 & -3.061 & -1.63 & 0.0 & $1.26 \times 10^{20}$ \\
\hline $\mathrm{Se}, \mathrm{Bi}_{12} \mathrm{GeO}_{20}, \mathrm{Bi}_{2} \mathrm{O}_{2} \mathrm{Se}, \mathrm{Bi}_{2} \mathrm{O}_{3}$ & -0.603 & -0.708 & -3.224 & -1.61 & 0.0 & $1.26 \times 10^{20}$ \\
\hline $\mathrm{Se}, \mathrm{Bi}_{2} \mathrm{O}_{2} \mathrm{Se}, \mathrm{Bi}_{4} \mathrm{Ge}_{3} \mathrm{O}_{12}, \mathrm{Bi}_{2} \mathrm{Se}_{3}$ & -0.378 & -0.708 & -2.515 & -1.835 & 0.0 & $1.25 \times 10^{20}$ \\
\hline $\mathrm{Se}, \mathrm{Bi}_{12} \mathrm{GeO}_{20}, \mathrm{Cu}_{3} \mathrm{Se}_{2}, \mathrm{Bi}_{2} \mathrm{O}_{3}$ & -0.865 & -0.62 & -3.574 & -1.435 & 0.0 & $7.5 \times 10^{19}$ \\
\hline $\mathrm{Se}, \mathrm{Bi}_{12} \mathrm{GeO}_{20}, \mathrm{Bi}_{4} \mathrm{Ge}_{3} \mathrm{O}_{12}, \mathrm{Cu}_{3} \mathrm{Se}_{2}$ & -0.845 & -0.62 & -3.411 & -1.455 & 0.0 & $7.48 \times 10^{19}$ \\
\hline $\mathrm{Bi}, \mathrm{Bi}_{2} \mathrm{O}_{2} \mathrm{Se}, \mathrm{Bi}_{4} \mathrm{Ge}_{3} \mathrm{O}_{12}, \mathrm{Bi}_{2} \mathrm{Se}_{3}$ & 0.0 & -0.582 & -2.012 & -2.087 & -0.252 & $5.39 \times 10^{19}$ \\
\hline $\mathrm{Bi}, \mathrm{Bi}_{12} \mathrm{GeO}_{20}, \mathrm{Bi}_{2} \mathrm{O}_{2} \mathrm{Se}, \mathrm{Bi}_{2} \mathrm{O}_{3}$ & 0.0 & -0.507 & -2.421 & -2.012 & -0.402 & $3.45 \times 10^{19}$ \\
\hline $\mathrm{Bi}, \mathrm{Bi}_{12} \mathrm{GeO}_{20}, \mathrm{Bi}_{2} \mathrm{O}_{2} \mathrm{Se}, \mathrm{Bi}_{4} \mathrm{Ge}_{3} \mathrm{O}_{12}$ & 0.0 & -0.514 & -2.284 & -2.018 & -0.388 & $3.62 \times 10^{19}$ \\
\hline $\mathrm{Bi}, \mathrm{Bi}_{4} \mathrm{Ge}_{3} \mathrm{O}_{12}, \mathrm{Cu}_{3} \mathrm{Se}_{2}, \mathrm{Bi}_{2} \mathrm{Se}_{3}$ & 0.0 & -0.452 & -1.494 & -2.216 & -0.252 & $2.34 \times 10^{19}$ \\
\hline $\mathrm{Bi}, \mathrm{Cu}_{2} \mathrm{Se}, \mathrm{Bi}_{4} \mathrm{Ge}_{3} \mathrm{O}_{12}, \mathrm{Cu}_{3} \mathrm{Se}_{2}$ & 0.0 & -0.318 & -1.762 & -2.149 & -0.453 & $1.1 \times 10^{19}$ \\
\hline $\mathrm{Bi}, \mathrm{Cu}_{2} \mathrm{Se}, \mathrm{Cu}_{2} \mathrm{O}, \mathrm{Bi}_{4} \mathrm{Ge}_{3} \mathrm{O}_{12}$ & 0.0 & -0.223 & -2.142 & -2.054 & -0.643 & $5.11 \times 10^{18}$ \\
\hline $\mathrm{Bi}, \mathrm{Bi}_{12} \mathrm{GeO}_{20}, \mathrm{Cu}_{2} \mathrm{O}, \mathrm{Bi}_{2} \mathrm{O}_{3}$ & 0.0 & -0.244 & -2.421 & -2.012 & -0.664 & $5.61 \times 10^{18}$ \\
\hline $\mathrm{Bi}, \mathrm{Bi}_{12} \mathrm{GeO}_{20}, \mathrm{Cu}_{2} \mathrm{O}, \mathrm{Bi}_{4} \mathrm{Ge}_{3} \mathrm{O}_{12}$ & 0.0 & -0.241 & -2.284 & -2.018 & -0.661 & $5.54 \times 10^{18}$ \\
\hline $\mathrm{Cu}_{2} \mathrm{Se}, \mathrm{Cu}_{2} \mathrm{O}, \mathrm{Bi}_{4} \mathrm{Ge}_{3} \mathrm{O}_{12}, \mathrm{Cu}_{3} \mathrm{Se}_{2}$ & -0.285 & -0.318 & -2.522 & -1.864 & -0.453 & $1.13 \times 10^{19}$ \\
\hline $\mathrm{Bi}_{12} \mathrm{GeO}_{20}, \mathrm{Cu}_{2} \mathrm{O}, \mathrm{Cu}_{3} \mathrm{Se}_{2}, \mathrm{Bi}_{2} \mathrm{O}_{3}$ & -0.603 & -0.445 & -3.224 & -1.61 & -0.262 & $2.61 \times 10^{19}$ \\
\hline $\mathrm{Bi}_{12} \mathrm{GeO}_{20}, \mathrm{Cu}_{2} \mathrm{O}, \mathrm{Bi}_{4} \mathrm{Ge}_{3} \mathrm{O}_{12}, \mathrm{Cu}_{3} \mathrm{Se}_{2}$ & -0.552 & -0.425 & -3.02 & -1.651 & -0.293 & $2.3 \times 10^{19}$ \\
\hline
\end{tabular}

Table S15: Chemical potentials $\Delta \mu_{\mathrm{i}}$ (in eV) in all phase regions of the quinary Bi-Cu-Se-O-Ge phase space that are in equilibrium with $\mathrm{BiCuSeO}$. The corresponding charge carrier concentration in each phase region, as determined by charge neutrality at the typical synthesis temperature of $973 \mathrm{~K}$, is listed. 


\section{Phase Equilibriua of Sn-Doped BiCuSeO}

\begin{tabular}{|c|c|c|c|c|c|c|}
\hline Equilibrium Phases & $\Delta \mu_{\mathrm{Bi}}$ & $\Delta \mu_{\mathrm{Cu}}$ & $\Delta \mu_{\mathrm{O}}$ & $\Delta \mu_{\mathrm{Se}}$ & $\Delta \mu_{\mathrm{Sn}}$ & $p-n\left(\mathrm{~cm}^{-3}\right)$ \\
\hline $\mathrm{Se}, \mathrm{O}_{2} \mathrm{Sn}, \mathrm{Cu}_{3} \mathrm{Se}_{2}, \mathrm{Bi}_{2} \mathrm{Se}_{3}$ & -0.378 & -0.62 & -1.923 & 0.0 & -1.897 & $7.36 \times 10^{19}$ \\
\hline $\mathrm{Se}, \mathrm{Bi}_{2} \mathrm{O}_{2} \mathrm{Se}, \mathrm{Bi}_{2} \mathrm{O}_{7} \mathrm{Sn}_{2}, \mathrm{Bi}_{2} \mathrm{O}_{3}$ & -0.603 & -0.708 & -1.61 & 0.0 & -2.676 & $1.26 \times 10^{20}$ \\
\hline $\mathrm{Se}, \mathrm{Bi}_{2} \mathrm{O}_{2} \mathrm{Se}, \mathrm{Bi}_{2} \mathrm{O}_{7} \mathrm{Sn}_{2}, \mathrm{Bi}_{2} \mathrm{Se}_{3}$ & -0.378 & -0.708 & -1.835 & 0.0 & -2.113 & $1.25 \times 10^{20}$ \\
\hline $\mathrm{Se}, \mathrm{O}_{2} \mathrm{Sn}, \mathrm{Bi}_{2} \mathrm{O}_{7} \mathrm{Sn}_{2}, \mathrm{Bi}_{2} \mathrm{Se}_{3}$ & -0.378 & -0.68 & -1.863 & 0.0 & -2.017 & $1.06 \times 10^{20}$ \\
\hline $\mathrm{Se}, \mathrm{O}_{2} \mathrm{Sn}, \mathrm{Bi}_{2} \mathrm{O}_{7} \mathrm{Sn}_{2}, \mathrm{Cu}_{3} \mathrm{Se}_{2}$ & -0.557 & -0.62 & -1.743 & 0.0 & -2.256 & $7.48 \times 10^{19}$ \\
\hline $\mathrm{Se}, \mathrm{Bi}_{2} \mathrm{O}_{7} \mathrm{Sn}_{2}, \mathrm{Cu}_{3} \mathrm{Se}_{2}, \mathrm{Bi}_{2} \mathrm{O}_{3}$ & -0.865 & -0.62 & -1.435 & 0.0 & -3.026 & $7.5 \times 10^{19}$ \\
\hline $\mathrm{Cu}_{2} \mathrm{O}, \mathrm{Bi}_{2} \mathrm{O}_{7} \mathrm{Sn}_{2}, \mathrm{Cu}_{2} \mathrm{Se}, \mathrm{Cu}_{3} \mathrm{Se}_{2}$ & -0.285 & -0.318 & -1.864 & -0.453 & -2.104 & $1.13 \times 10^{19}$ \\
\hline $\mathrm{O}_{2} \mathrm{Sn}, \mathrm{Bi}_{2} \mathrm{O}_{7} \mathrm{Sn}_{2}, \mathrm{Cu}_{2} \mathrm{Se}, \mathrm{Cu}_{3} \mathrm{Se}_{2}$ & -0.104 & -0.318 & -2.045 & -0.453 & -1.652 & $1.13 \times 10^{19}$ \\
\hline $\mathrm{Cu}_{2} \mathrm{O}, \mathrm{Bi}_{2} \mathrm{O}_{7} \mathrm{Sn}_{2}, \mathrm{Cu}_{3} \mathrm{Se}_{2}, \mathrm{Bi}_{2} \mathrm{O}_{3}$ & -0.603 & -0.445 & -1.61 & -0.262 & -2.676 & $2.61 \times 10^{19}$ \\
\hline $\mathrm{Bi}, \mathrm{Cu}_{2} \mathrm{O}, \mathrm{Bi}_{2} \mathrm{O}_{7} \mathrm{Sn}_{2}, \mathrm{Bi}_{2} \mathrm{O}_{3}$ & 0.0 & -0.244 & -2.012 & -0.664 & -1.873 & $5.61 \times 10^{18}$ \\
\hline $\mathrm{Bi}, \mathrm{O}_{2} \mathrm{Sn}, \mathrm{Bi}_{2} \mathrm{O}_{7} \mathrm{Sn}_{2}, \mathrm{Cu}_{2} \mathrm{Se}$ & 0.0 & -0.283 & -2.114 & -0.522 & -1.513 & $8.61 \times 10^{18}$ \\
\hline $\mathrm{Bi}, \mathrm{Cu}_{2} \mathrm{O}, \mathrm{Bi}_{2} \mathrm{O}_{7} \mathrm{Sn}_{2}, \mathrm{Cu}_{2} \mathrm{Se}$ & 0.0 & -0.223 & -2.054 & -0.643 & -1.724 & $5.11 \times 10^{18}$ \\
\hline $\mathrm{Bi}, \mathrm{O}_{2} \mathrm{Sn}, \mathrm{Cu}_{2} \mathrm{Se}, \mathrm{Cu}_{3} \mathrm{Se}_{2}$ & 0.0 & -0.318 & -2.149 & -0.453 & -1.444 & $1.11 \times 10^{19}$ \\
\hline $\mathrm{Bi}, \mathrm{O}_{2} \mathrm{Sn}, \mathrm{Cu}_{3} \mathrm{Se}_{2}, \mathrm{Bi}_{2} \mathrm{Se}_{3}$ & 0.0 & -0.452 & -2.216 & -0.252 & -1.31 & $2.34 \times 10^{19}$ \\
\hline $\mathrm{Bi}, \mathrm{Bi}_{2} \mathrm{O}_{2} \mathrm{Se}, \mathrm{Bi}_{2} \mathrm{O}_{7} \mathrm{Sn}_{2}, \mathrm{Bi}_{2} \mathrm{O}_{3}$ & 0.0 & -0.507 & -2.012 & -0.402 & -1.873 & $3.45 \times 10^{19}$ \\
\hline $\mathrm{Bi}, \mathrm{Bi}_{2} \mathrm{O}_{2} \mathrm{Se}, \mathrm{Bi}_{2} \mathrm{O}_{7} \mathrm{Sn}_{2}, \mathrm{Bi}_{2} \mathrm{Se}_{3}$ & 0.0 & -0.582 & -2.087 & -0.252 & -1.61 & $5.39 \times 10^{19}$ \\
\hline $\mathrm{Bi}, \mathrm{O}_{2} \mathrm{Sn}, \mathrm{Bi}_{2} \mathrm{O}_{7} \mathrm{Sn}_{2}, \mathrm{Bi}_{2} \mathrm{Se}_{3}$ & 0.0 & -0.554 & -2.114 & -0.252 & -1.513 & $4.52 \times 10^{19}$ \\
\hline
\end{tabular}

Table S16: Chemical potentials $\Delta \mu_{\mathrm{i}}$ (in eV) in all phase regions of the quinary Bi-Cu-Se-O-Sn phase space that are in equilibrium with $\mathrm{BiCuSeO}$. The corresponding charge carrier concentration in each phase region, as determined by charge neutrality at the typical synthesis temperature of $973 \mathrm{~K}$, is listed. 


\section{Phase Equilibriua of $\mathrm{Pb}-\mathrm{Doped} \mathrm{BiCuSeO}$}

\begin{tabular}{|c|c|c|c|c|c|c|}
\hline Equilibrium Phases & $\Delta \mu_{\mathrm{Bi}}$ & $\Delta \mu_{\mathrm{Cu}}$ & $\Delta \mu_{\mathrm{O}}$ & $\Delta \mu_{\mathrm{Pb}}$ & $\Delta \mu_{\mathrm{Se}}$ & $p-n\left(\mathrm{~cm}^{-3}\right)$ \\
\hline $\mathrm{Se}, \mathrm{PbSe}, \mathrm{Cu}_{3} \mathrm{Se}_{2}, \mathrm{Bi}_{2} \mathrm{Se}_{3}$ & -0.378 & -0.62 & -1.923 & -0.942 & 0.0 & $8.28 \times 10^{19}$ \\
\hline $\mathrm{Se}, \mathrm{PbSe}, \mathrm{Bi}_{2} \mathrm{O}_{2} \mathrm{Se}, \mathrm{Bi}_{2} \mathrm{O}_{3}$ & -0.602 & -0.708 & -1.61 & -0.942 & 0.0 & $1.92 \times 10^{20}$ \\
\hline $\mathrm{Se}, \mathrm{PbSe}, \mathrm{Bi}_{2} \mathrm{O}_{2} \mathrm{Se}, \mathrm{Bi}_{2} \mathrm{Se}_{3}$ & -0.378 & -0.708 & -1.835 & -0.942 & 0.0 & $1.3 \times 10^{20}$ \\
\hline $\mathrm{Se}, \mathrm{PbSe}, \mathrm{Cu}_{3} \mathrm{Se}_{2}, \mathrm{O}_{5} \mathrm{~Pb}_{3} \mathrm{Se}$ & -0.772 & -0.62 & -1.528 & -0.942 & 0.0 & $4 \times 10^{20}$ \\
\hline $\mathrm{Se}, \mathrm{O}_{3} \mathrm{PbSe}, \mathrm{Cu}_{3} \mathrm{Se}_{2}, \mathrm{O}_{5} \mathrm{~Pb}_{3} \mathrm{Se}$ & -0.773 & -0.62 & -1.527 & -0.943 & 0.0 & $4 \times 10^{20}$ \\
\hline $\mathrm{Se}, \mathrm{O}_{3} \mathrm{PbSe}, \mathrm{Cu}_{3} \mathrm{Se}_{2}, \mathrm{Bi}_{2} \mathrm{O}_{3}$ & -0.865 & -0.62 & -1.435 & -1.22 & 0.0 & $1.54 \times 10^{20}$ \\
\hline $\mathrm{Se}, \mathrm{O}_{3} \mathrm{PbSe}, \mathrm{Bi}_{2} \mathrm{O}_{3}, \mathrm{O}_{5} \mathrm{~Pb}_{3} \mathrm{Se}$ & -0.727 & -0.666 & -1.527 & -0.943 & 0.0 & $3.17 \times 10^{20}$ \\
\hline $\mathrm{Se}, \mathrm{PbSe}, \mathrm{Bi}_{2} \mathrm{O}_{3}, \mathrm{O}_{5} \mathrm{~Pb}_{3} \mathrm{Se}$ & -0.726 & -0.667 & -1.528 & -0.942 & 0.0 & $3.17 \times 10^{20}$ \\
\hline $\mathrm{Bi}, \mathrm{PbSe}, \mathrm{Bi}_{2} \mathrm{O}_{2} \mathrm{Se}, \mathrm{Bi}_{2} \mathrm{Se}_{3}$ & 0.0 & -0.582 & -2.087 & -0.69 & -0.252 & $5.62 \times 10^{19}$ \\
\hline $\mathrm{Bi}, \mathrm{Cu}_{2} \mathrm{Se}, \mathrm{Cu}_{2} \mathrm{O}_{2} \mathrm{~Pb}, \mathrm{OPb}$ & 0.0 & -0.228 & -2.059 & -0.335 & -0.632 & $6.01 \times 10^{19}$ \\
\hline $\mathrm{Bi}, \mathrm{PbSe}, \mathrm{Cu}_{2} \mathrm{Se}, \mathrm{OPb}$ & 0.0 & -0.237 & -2.068 & -0.326 & -0.616 & $6.59 \times 10^{19}$ \\
\hline $\mathrm{Bi}, \mathrm{Cu}_{2} \mathrm{Se}, \mathrm{Cu}_{2} \mathrm{O}, \mathrm{Cu}_{2} \mathrm{O}_{2} \mathrm{~Pb}$ & 0.0 & -0.223 & -2.054 & -0.356 & -0.643 & $5.31 \times 10^{19}$ \\
\hline $\mathrm{Bi}, \mathrm{Cu}_{2} \mathrm{O}_{2} \mathrm{~Pb}, \mathrm{Bi}_{2} \mathrm{O}_{3}, \mathrm{OPb}$ & 0.0 & -0.252 & -2.012 & -0.382 & -0.656 & $4.6 \times 10^{19}$ \\
\hline $\mathrm{Bi}, \mathrm{Cu}_{2} \mathrm{O}, \mathrm{Cu}_{2} \mathrm{O}_{2} \mathrm{~Pb}, \mathrm{Bi}_{2} \mathrm{O}_{3}$ & 0.0 & -0.244 & -2.012 & -0.398 & -0.664 & $4.18 \times 10^{19}$ \\
\hline $\mathrm{Bi}, \mathrm{PbSe}, \mathrm{Bi}_{2} \mathrm{O}_{3}, \mathrm{OPb}$ & 0.0 & -0.349 & -2.012 & -0.382 & -0.56 & $6.32 \times 10^{19}$ \\
\hline $\mathrm{Bi}, \mathrm{PbSe}, \mathrm{Bi}_{2} \mathrm{O}_{2} \mathrm{Se}, \mathrm{Bi}_{2} \mathrm{O}_{3}$ & 0.0 & -0.507 & -2.012 & -0.54 & -0.402 & $5.11 \times 10^{19}$ \\
\hline $\mathrm{Bi}, \mathrm{PbSe}, \mathrm{Cu}_{3} \mathrm{Se}_{2}, \mathrm{Bi}_{2} \mathrm{Se}_{3}$ & 0.0 & -0.452 & -2.216 & -0.69 & -0.252 & $2.74 \times 10^{19}$ \\
\hline $\mathrm{Bi}, \mathrm{PbSe}, \mathrm{Cu}_{2} \mathrm{Se}, \mathrm{Cu}_{3} \mathrm{Se}_{2}$ & 0.0 & -0.318 & -2.149 & -0.489 & -0.453 & $4.58 \times 10^{19}$ \\
\hline $\mathrm{Cu}_{2} \mathrm{O}, \mathrm{Cu}_{2} \mathrm{O}_{2} \mathrm{~Pb}, \mathrm{Cu}_{3} \mathrm{Se}_{2}, \mathrm{Bi}_{2} \mathrm{O}_{3}$ & -0.603 & -0.445 & -1.61 & -0.8 & -0.262 & $2.94 \times 10^{20}$ \\
\hline $\mathrm{Cu}_{2} \mathrm{O}_{2} \mathrm{~Pb}, \mathrm{Cu}_{3} \mathrm{Se}_{2}, \mathrm{Bi}_{2} \mathrm{O}_{3}, \mathrm{OPb}$ & -0.627 & -0.461 & -1.594 & -0.8 & -0.238 & $3.42 \times 10^{20}$ \\
\hline $\mathrm{PbSe}, \mathrm{Cu}_{3} \mathrm{Se}_{2}, \mathrm{O}_{5} \mathrm{~Pb}_{3} \mathrm{Se}, \mathrm{OPb}$ & -0.679 & -0.536 & -1.579 & -0.815 & -0.127 & $4.58 \times 10^{20}$ \\
\hline $\mathrm{Cu}_{3} \mathrm{Se}_{2}, \mathrm{Bi}_{2} \mathrm{O}_{3}, \mathrm{O}_{5} \mathrm{~Pb}_{3} \mathrm{Se}, \mathrm{OPb}$ & -0.688 & -0.502 & -1.553 & -0.841 & -0.178 & $4.03 \times 10^{20}$ \\
\hline $\mathrm{O}_{3} \mathrm{PbSe}, \mathrm{Cu}_{3} \mathrm{Se}_{2}, \mathrm{Bi}_{2} \mathrm{O}_{3}, \mathrm{O}_{5} \mathrm{~Pb}_{3} \mathrm{Se}$ & -0.786 & -0.567 & -1.488 & -0.983 & -0.079 & $3.36 \times 10^{20}$ \\
\hline $\mathrm{PbSe}, \mathrm{Bi}_{2} \mathrm{O}_{3}, \mathrm{O}_{5} \mathrm{~Pb}_{3} \mathrm{Se}, \mathrm{OPb}$ & -0.649 & -0.565 & -1.579 & -0.815 & -0.127 & $3.91 \times 10^{20}$ \\
\hline $\mathrm{PbSe}, \mathrm{Cu}_{2} \mathrm{Se}, \mathrm{Cu}_{3} \mathrm{Se}_{2}, \mathrm{OPb}$ & -0.244 & -0.318 & -1.905 & -0.489 & -0.453 & $1.56 \times 10^{20}$ \\
\hline $\mathrm{Cu}_{2} \mathrm{Se}, \mathrm{Cu}_{2} \mathrm{O}_{2} \mathrm{~Pb}, \mathrm{Cu}_{3} \mathrm{Se}_{2}, \mathrm{OPb}$ & -0.269 & -0.318 & -1.88 & -0.514 & -0.453 & $1.56 \times 10^{20}$ \\
\hline $\mathrm{Cu}_{2} \mathrm{Se}, \mathrm{Cu}_{2} \mathrm{O}, \mathrm{Cu}_{2} \mathrm{O}_{2} \mathrm{~Pb}, \mathrm{Cu}_{3} \mathrm{Se}_{2}$ & -0.285 & -0.318 & -1.864 & -0.546 & -0.453 & $1.46 \times 10^{20}$ \\
\hline
\end{tabular}

Table S17: Chemical potentials $\Delta \mu_{\mathrm{i}}$ (in eV) in all phase regions of the quinary Bi-Cu-Se-O-Pb phase space that are in equilibrium with $\mathrm{BiCuSeO}$. The corresponding charge carrier concentration in each phase region, as determined by charge neutrality at the typical synthesis temperature of $973 \mathrm{~K}$, is listed. 


\section{Phase Equilibriua of Sc-Doped BiCuSeO}

\begin{tabular}{|c|c|c|c|c|c|c|}
\hline Equilibrium Phases & $\Delta \mu_{\mathrm{Bi}}$ & $\Delta \mu_{\mathrm{Cu}}$ & $\Delta \mu_{\mathrm{O}}$ & $\Delta \mu_{\mathrm{Sc}}$ & $\Delta \mu_{\mathrm{Se}}$ & $p-n\left(\mathrm{~cm}^{-3}\right)$ \\
\hline $\mathrm{Se}, \mathrm{O}_{3} \mathrm{Sc}_{2}, \mathrm{Cu}_{3} \mathrm{Se}_{2}, \mathrm{Bi}_{2} \mathrm{Se}_{3}$ & -0.378 & -0.62 & -1.923 & -6.969 & 0.0 & $7.36 \times 10^{19}$ \\
\hline $\mathrm{Se}, \mathrm{O}_{3} \mathrm{Sc}_{2}, \mathrm{Bi}_{2} \mathrm{O}_{2} \mathrm{Se}, \mathrm{Bi}_{2} \mathrm{O}_{3}$ & -0.602 & -0.708 & -1.61 & -7.437 & 0.0 & $1.26 \times 10^{20}$ \\
\hline $\mathrm{Se}, \mathrm{O}_{3} \mathrm{Sc}_{2}, \mathrm{Bi}_{2} \mathrm{O}_{2} \mathrm{Se}, \mathrm{Bi}_{2} \mathrm{Se}_{3}$ & -0.378 & -0.708 & -1.835 & -7.1 & 0.0 & $1.25 \times 10^{20}$ \\
\hline $\mathrm{Se}, \mathrm{O}_{3} \mathrm{Sc}_{2}, \mathrm{Cu}_{3} \mathrm{Se}_{2}, \mathrm{Bi}_{2} \mathrm{O}_{3}$ & -0.865 & -0.62 & -1.435 & -7.7 & 0.0 & $7.5 \times 10^{19}$ \\
\hline $\mathrm{Bi}, \mathrm{O}_{3} \mathrm{Sc}_{2}, \mathrm{Bi}_{2} \mathrm{O}_{2} \mathrm{Se}, \mathrm{Bi}_{2} \mathrm{Se}_{3}$ & 0.0 & -0.582 & -2.087 & -6.723 & -0.252 & $5.39 \times 10^{19}$ \\
\hline $\mathrm{Bi}, \mathrm{Cu}_{2} \mathrm{Se}, \mathrm{Cu}_{2} \mathrm{O}, \mathrm{CuO}_{2} \mathrm{Sc}$ & 0.0 & -0.223 & -2.054 & -6.817 & -0.643 & $5.11 \times 10^{18}$ \\
\hline $\mathrm{Bi}, \mathrm{O}_{3} \mathrm{Sc}_{2}, \mathrm{Cu}_{2} \mathrm{Se}, \mathrm{CuO}_{2} \mathrm{Sc}$ & 0.0 & -0.253 & -2.084 & -6.726 & -0.582 & $6.72 \times 10^{18}$ \\
\hline $\mathrm{Bi}, \mathrm{O}_{3} \mathrm{Sc}_{2}, \mathrm{CuO}_{2} \mathrm{Sc}, \mathrm{Bi}_{2} \mathrm{O}_{3}$ & 0.0 & -0.29 & -2.012 & -6.835 & -0.619 & $7.98 \times 10^{18}$ \\
\hline $\mathrm{Bi}, \mathrm{Cu}_{2} \mathrm{O}, \mathrm{CuO}_{2} \mathrm{Sc}, \mathrm{Bi}_{2} \mathrm{O}_{3}$ & 0.0 & -0.244 & -2.012 & -6.881 & -0.664 & $5.61 \times 10^{18}$ \\
\hline $\mathrm{Bi}, \mathrm{O}_{3} \mathrm{Sc}_{2}, \mathrm{Bi}_{2} \mathrm{O}_{2} \mathrm{Se}, \mathrm{Bi}_{2} \mathrm{O}_{3}$ & 0.0 & -0.507 & -2.012 & -6.835 & -0.402 & $3.45 \times 10^{19}$ \\
\hline $\mathrm{Bi}, \mathrm{O}_{3} \mathrm{Sc}_{2}, \mathrm{Cu}_{3} \mathrm{Se}_{2}, \mathrm{Bi}_{2} \mathrm{Se}_{3}$ & 0.0 & -0.452 & -2.216 & -6.528 & -0.252 & $2.34 \times 10^{19}$ \\
\hline $\mathrm{Bi}, \mathrm{O}_{3} \mathrm{Sc}_{2}, \mathrm{Cu}_{2} \mathrm{Se}, \mathrm{Cu}_{3} \mathrm{Se}_{2}$ & 0.0 & -0.318 & -2.149 & -6.629 & -0.453 & $1.1 \times 10^{19}$ \\
\hline $\mathrm{O}_{3} \mathrm{Sc}_{2}, \mathrm{Cu}_{2} \mathrm{Se}, \mathrm{CuO}_{2} \mathrm{Sc}, \mathrm{Cu}_{3} \mathrm{Se}_{2}$ & -0.194 & -0.318 & -1.955 & -6.92 & -0.453 & $1.13 \times 10^{19}$ \\
\hline $\mathrm{Cu}_{2} \mathrm{Se}, \mathrm{Cu}_{2} \mathrm{O}, \mathrm{CuO}_{2} \mathrm{Sc}, \mathrm{Cu}_{3} \mathrm{Se}_{2}$ & -0.285 & -0.318 & -1.864 & -7.102 & -0.453 & $1.13 \times 10^{19}$ \\
\hline $\mathrm{O}_{3} \mathrm{Sc}_{2}, \mathrm{CuO}_{2} \mathrm{Sc}, \mathrm{Cu}_{3} \mathrm{Se}_{2}, \mathrm{Bi}_{2} \mathrm{O}_{3}$ & -0.739 & -0.536 & -1.519 & -7.574 & -0.126 & $4.54 \times 10^{19}$ \\
\hline $\mathrm{Cu}_{2} \mathrm{O}, \mathrm{CuO}_{2} \mathrm{Sc}, \mathrm{Cu}_{3} \mathrm{Se}_{2}, \mathrm{Bi}_{2} \mathrm{O}_{3}$ & -0.603 & -0.445 & -1.61 & -7.483 & -0.262 & $2.61 \times 10^{19}$ \\
\hline
\end{tabular}

Table S18: Chemical potentials $\Delta \mu_{\mathrm{i}}$ (in eV) in all phase regions of the quinary Bi-Cu-Se-O-Sc phase space that are in equilibrium with $\mathrm{BiCuSeO}$. The corresponding charge carrier concentration in each phase region, as determined by charge neutrality at the typical synthesis temperature of $973 \mathrm{~K}$, is listed. 


\section{Phase Equilibriua of Y-Doped BiCuSeO}

\begin{tabular}{lcccccc}
\hline Equilibrium Phases & $\Delta \mu_{\mathrm{Bi}}$ & $\Delta \mu_{\mathrm{Cu}}$ & $\Delta \mu_{\mathrm{O}}$ & $\Delta \mu_{\mathrm{Se}}$ & $\Delta \mu_{\mathrm{Y}}$ & $p-n\left(\mathrm{~cm}^{-3}\right)$ \\
\hline $\mathrm{Bi}, \mathrm{Bi}_{2} \mathrm{O}_{2} \mathrm{Se}, \mathrm{Bi}_{2} \mathrm{Se}_{3}, \mathrm{O}_{3} \mathrm{Y}_{2}$ & 0.0 & -0.582 & -2.087 & -0.252 & -6.748 & $5.31 \mathrm{e}+19$ \\
$\mathrm{Bi}, \mathrm{Cu}_{2} \mathrm{O}, \mathrm{Bi}_{2} \mathrm{O}_{3}, \mathrm{O}_{3} \mathrm{Y}_{2}$ & 0.0 & -0.244 & -2.012 & -0.664 & -6.86 & $5.59 \mathrm{e}+18$ \\
$\mathrm{Bi}, \mathrm{Cu}_{2} \mathrm{Se}, \mathrm{Cu}_{2} \mathrm{O}, \mathrm{O}_{3} \mathrm{Y}_{2}$ & 0.0 & -0.223 & -2.054 & -0.643 & -6.796 & $5.08 \mathrm{e}+18$ \\
$\mathrm{Bi}, \mathrm{Bi}_{2} \mathrm{O}_{2} \mathrm{Se}_{,} \mathrm{Bi}_{2} \mathrm{O}_{3}, \mathrm{O}_{3} \mathrm{Y}_{2}$ & 0.0 & -0.507 & -2.012 & -0.402 & -6.86 & $3.44 \mathrm{e}+19$ \\
$\mathrm{Bi}, \mathrm{Cu}_{3} \mathrm{Se}_{2}, \mathrm{Bi}_{2} \mathrm{Se}_{3}, \mathrm{O}_{3} \mathrm{Y}_{2}$ & 0.0 & -0.452 & -2.216 & -0.252 & -6.553 & $2.04 \mathrm{e}+19$ \\
$\mathrm{Bi}, \mathrm{Cu}_{2} \mathrm{Se}_{2} \mathrm{Cu}_{3} \mathrm{Se}_{2}, \mathrm{O}_{3} \mathrm{Y}_{2}$ & 0.0 & -0.318 & -2.149 & -0.453 & -6.654 & $1.05 \mathrm{e}+19$ \\
$\mathrm{Cu} \mathrm{Se}_{2} \mathrm{Cu}_{2} \mathrm{O}, \mathrm{Cu}_{3} \mathrm{Se}_{2}, \mathrm{O}_{3} \mathrm{Y}_{2}$ & -0.285 & -0.318 & -1.864 & -0.453 & -7.082 & $1.12 \mathrm{e}+19$ \\
$\mathrm{Cu}_{2} \mathrm{O}, \mathrm{Cu}_{3} \mathrm{Se}_{2}, \mathrm{Bi}_{2} \mathrm{O}_{3}, \mathrm{O}_{3} \mathrm{Y}_{2}$ & -0.603 & -0.445 & -1.61 & -0.262 & -7.463 & $2.59 \mathrm{e}+19$ \\
$\mathrm{Se}, \mathrm{Cu}_{3} \mathrm{Se}_{2}, \mathrm{Bi}_{2} \mathrm{O}_{3}, \mathrm{O}_{3} \mathrm{Y}_{2}$ & -0.865 & -0.62 & -1.435 & 0.0 & -7.725 & $7.46 \mathrm{e}+19$ \\
$\mathrm{Se}, \mathrm{Bi}_{2} \mathrm{O}_{2} \mathrm{Se}_{2} \mathrm{Bi}_{2} \mathrm{Se}_{3}, \mathrm{O}_{3} \mathrm{Y}_{2}$ & -0.378 & -0.708 & -1.835 & 0.0 & -7.125 & $1.22 \mathrm{e}+20$ \\
$\mathrm{Se}, \mathrm{Bi}_{2} \mathrm{O}_{2} \mathrm{Se}_{2} \mathrm{Bi}_{2} \mathrm{O}_{3}, \mathrm{O}_{3} \mathrm{Y}_{2}$ & -0.602 & -0.708 & -1.61 & 0.0 & -7.462 & $1.25 \mathrm{e}+20$ \\
$\mathrm{Se}, \mathrm{Cu}_{3} \mathrm{Se}_{2}, \mathrm{Bi}_{2} \mathrm{Se}_{3}, \mathrm{O}_{3} \mathrm{Y}_{2}$ & -0.378 & -0.62 & -1.923 & 0.0 & -6.994 & $6.67 \mathrm{e}+19$ \\
\hline
\end{tabular}

Table S19: Chemical potentials $\Delta \mu_{\mathrm{i}}$ (in eV) in all phase regions of the quinary Bi-Cu-Se-O-Y phase space that are in equilibrium with $\mathrm{BiCuSeO}$. The corresponding charge carrier concentration in each phase region, as determined by charge neutrality at the typical synthesis temperature of $973 \mathrm{~K}$, is listed. 


\section{Phase Equilibriua of Ti-Doped BiCuSeO}

\begin{tabular}{|c|c|c|c|c|c|c|}
\hline Equilibrium Phases & $\Delta \mu_{\mathrm{Bi}}$ & $\Delta \mu_{\mathrm{Cu}}$ & $\Delta \mu_{\mathrm{O}}$ & $\Delta \mu_{\mathrm{Se}}$ & $\Delta \mu_{\mathrm{Ti}}$ & $p-n\left(\mathrm{~cm}^{-3}\right)$ \\
\hline $\mathrm{Bi}, \mathrm{Bi}_{2} \mathrm{O}_{2} \mathrm{Se}, \mathrm{Bi}_{2} \mathrm{O}_{7} \mathrm{Ti}_{2}, \mathrm{Bi}_{2} \mathrm{Se}_{3}$ & 0.0 & -0.582 & -2.087 & -0.252 & -5.733 & $5.39 \times 10^{19}$ \\
\hline $\mathrm{Bi}, \mathrm{Bi}_{2} \mathrm{O}_{7} \mathrm{Ti}_{2}, \mathrm{O}_{2} \mathrm{Ti}, \mathrm{Bi}_{2} \mathrm{Se}_{3}$ & 0.0 & -0.567 & -2.101 & -0.252 & -5.683 & $4.91 \times 10^{19}$ \\
\hline $\mathrm{Bi}, \mathrm{Bi}_{2} \mathrm{O}_{2} \mathrm{Se}, \mathrm{Bi}_{2} \mathrm{O}_{7} \mathrm{Ti}_{2}, \mathrm{Bi}_{2} \mathrm{O}_{3}$ & 0.0 & -0.507 & -2.012 & -0.402 & -5.996 & $3.45 \times 10^{19}$ \\
\hline $\mathrm{Bi}, \mathrm{Cu}_{2} \mathrm{Se}, \mathrm{Cu}_{2} \mathrm{O}, \mathrm{Bi}_{2} \mathrm{O}_{7} \mathrm{Ti}_{2}$ & 0.0 & -0.223 & -2.054 & -0.643 & -5.847 & $5.11 \times 10^{18}$ \\
\hline $\mathrm{Bi}, \mathrm{Cu}_{2} \mathrm{Se}, \mathrm{Bi}_{2} \mathrm{O}_{7} \mathrm{Ti}_{2}, \mathrm{O}_{2} \mathrm{Ti}$ & 0.0 & -0.27 & -2.101 & -0.549 & -5.683 & $7.74 \times 10^{18}$ \\
\hline $\mathrm{Bi}, \mathrm{Cu}_{2} \mathrm{O}, \mathrm{Bi}_{2} \mathrm{O}_{7} \mathrm{Ti}_{2}, \mathrm{Bi}_{2} \mathrm{O}_{3}$ & 0.0 & -0.244 & -2.012 & -0.664 & -5.996 & $5.61 \times 10^{18}$ \\
\hline $\mathrm{Bi}, \mathrm{Cu}_{3} \mathrm{Se}_{2}, \mathrm{O}_{2} \mathrm{Ti}, \mathrm{Bi}_{2} \mathrm{Se}_{3}$ & 0.0 & -0.452 & -2.216 & -0.252 & -5.453 & $2.34 \times 10^{19}$ \\
\hline $\mathrm{Bi}, \mathrm{Cu}_{2} \mathrm{Se}, \mathrm{Cu}_{3} \mathrm{Se}_{2}, \mathrm{O}_{2} \mathrm{Ti}$ & 0.0 & -0.318 & -2.149 & -0.453 & -5.587 & $1.1 \times 10^{19}$ \\
\hline $\mathrm{Cu}_{2} \mathrm{Se}, \mathrm{Cu}_{2} \mathrm{O}, \mathrm{Bi}_{2} \mathrm{O}_{7} \mathrm{Ti}_{2}, \mathrm{Cu}_{3} \mathrm{Se}_{2}$ & -0.285 & -0.318 & -1.864 & -0.453 & -6.227 & $1.13 \times 10^{19}$ \\
\hline $\mathrm{Cu}_{2} \mathrm{Se}, \mathrm{Bi}_{2} \mathrm{O}_{7} \mathrm{Ti}_{2}, \mathrm{Cu}_{3} \mathrm{Se}_{2}, \mathrm{O}_{2} \mathrm{Ti}$ & -0.144 & -0.318 & -2.005 & -0.453 & -5.875 & $1.13 \times 10^{19}$ \\
\hline $\mathrm{Cu}_{2} \mathrm{O}, \mathrm{Bi}_{2} \mathrm{O}_{7} \mathrm{Ti}_{2}, \mathrm{Cu}_{3} \mathrm{Se}_{2}, \mathrm{Bi}_{2} \mathrm{O}_{3}$ & -0.603 & -0.445 & -1.61 & -0.262 & -6.799 & $2.61 \times 10^{19}$ \\
\hline $\mathrm{Se}, \mathrm{Bi}_{2} \mathrm{O}_{7} \mathrm{Ti}_{2}, \mathrm{Cu}_{3} \mathrm{Se}_{2}, \mathrm{Bi}_{2} \mathrm{O}_{3}$ & -0.865 & -0.62 & -1.435 & 0.0 & -7.149 & $7.5 \times 10^{19}$ \\
\hline $\mathrm{Se}, \mathrm{Bi}_{2} \mathrm{O}_{7} \mathrm{Ti}_{2}, \mathrm{Cu}_{3} \mathrm{Se}_{2}, \mathrm{O}_{2} \mathrm{Ti}$ & -0.597 & -0.62 & -1.703 & 0.0 & -6.479 & $7.48 \times 10^{19}$ \\
\hline $\mathrm{Se}, \mathrm{Bi}_{2} \mathrm{O}_{2} \mathrm{Se}, \mathrm{Bi}_{2} \mathrm{O}_{7} \mathrm{Ti}_{2}, \mathrm{Bi}_{2} \mathrm{Se}_{3}$ & -0.378 & -0.708 & -1.835 & 0.0 & -6.237 & $1.25 \times 10^{20}$ \\
\hline $\mathrm{Se}, \mathrm{Bi}_{2} \mathrm{O}_{7} \mathrm{Ti}_{2}, \mathrm{O}_{2} \mathrm{Ti}, \mathrm{Bi}_{2} \mathrm{Se}_{3}$ & -0.378 & -0.693 & -1.849 & 0.0 & -6.186 & $1.14 \times 10^{20}$ \\
\hline $\mathrm{Se}, \mathrm{Bi}_{2} \mathrm{O}_{2} \mathrm{Se}, \mathrm{Bi}_{2} \mathrm{O}_{7} \mathrm{Ti}_{2}, \mathrm{Bi}_{2} \mathrm{O}_{3}$ & -0.602 & -0.708 & -1.61 & 0.0 & -6.799 & $1.26 \times 10^{20}$ \\
\hline $\mathrm{Se}, \mathrm{Cu}_{3} \mathrm{Se}_{2}, \mathrm{O}_{2} \mathrm{Ti}, \mathrm{Bi}_{2} \mathrm{Se}_{3}$ & -0.378 & -0.62 & -1.923 & 0.0 & -6.04 & $7.36 \times 10^{19}$ \\
\hline
\end{tabular}

Table S20: Chemical potentials $\Delta \mu_{\mathrm{i}}$ (in eV) in all phase regions of the quinary Bi-Cu-Se-O-Ti phase space that are in equilibrium with $\mathrm{BiCuSeO}$. The corresponding charge carrier concentration in each phase region, as determined by charge neutrality at the typical synthesis temperature of $973 \mathrm{~K}$, is listed. 


\section{Phase Equilibriua of Zr-Doped BiCuSeO}

\begin{tabular}{|c|c|c|c|c|c|c|}
\hline Equilibrium Phases & $\Delta \mu_{\mathrm{Bi}}$ & $\Delta \mu_{\mathrm{Cu}}$ & $\Delta \mu_{\mathrm{O}}$ & $\Delta \mu_{\mathrm{Se}}$ & $\Delta \mu_{\mathrm{Zr}}$ & $p-n\left(\mathrm{~cm}^{-3}\right)$ \\
\hline $\mathrm{Bi}, \mathrm{Bi}_{2} \mathrm{O}_{2} \mathrm{Se}, \mathrm{O}_{2} \mathrm{Zr}, \mathrm{Bi}_{2} \mathrm{Se}_{3}$ & 0.0 & -0.582 & -2.087 & -0.252 & -7.229 & $5.39 \times 10^{19}$ \\
\hline $\mathrm{Bi}, \mathrm{Cu}_{2} \mathrm{Se}, \mathrm{Cu}_{2} \mathrm{O}, \mathrm{O}_{2} \mathrm{Zr}$ & 0.0 & -0.223 & -2.054 & -0.643 & -7.294 & $5.11 \times 10^{18}$ \\
\hline $\mathrm{Bi}, \mathrm{Cu}_{2} \mathrm{O}, \mathrm{O}_{2} \mathrm{Zr}, \mathrm{Bi}_{2} \mathrm{O}_{3}$ & 0.0 & -0.244 & -2.012 & -0.664 & -7.379 & $5.61 \times 10^{18}$ \\
\hline $\mathrm{Bi}, \mathrm{Bi}_{2} \mathrm{O}_{2} \mathrm{Se}, \mathrm{O}_{2} \mathrm{Zr}, \mathrm{Bi}_{2} \mathrm{O}_{3}$ & 0.0 & -0.507 & -2.012 & -0.402 & -7.379 & $3.45 \times 10^{19}$ \\
\hline $\mathrm{Bi}, \mathrm{O}_{2} \mathrm{Zr}, \mathrm{Cu}_{3} \mathrm{Se}_{2}, \mathrm{Bi}_{2} \mathrm{Se}_{3}$ & 0.0 & -0.452 & -2.216 & -0.252 & -6.97 & $2.34 \times 10^{19}$ \\
\hline $\mathrm{Bi}, \mathrm{Cu}_{2} \mathrm{Se}, \mathrm{O}_{2} \mathrm{Zr}, \mathrm{Cu}_{3} \mathrm{Se}_{2}$ & 0.0 & -0.318 & -2.149 & -0.453 & -7.104 & $1.1 \times 10^{19}$ \\
\hline $\mathrm{Cu}_{2} \mathrm{O}, \mathrm{O}_{2} \mathrm{Zr}, \mathrm{Cu}_{3} \mathrm{Se}_{2}, \mathrm{Bi}_{2} \mathrm{O}_{3}$ & -0.603 & -0.445 & -1.61 & -0.262 & -8.182 & $2.61 \times 10^{19}$ \\
\hline $\mathrm{Cu}_{2} \mathrm{Se}, \mathrm{Cu}_{2} \mathrm{O}, \mathrm{O}_{2} \mathrm{Zr}, \mathrm{Cu}_{3} \mathrm{Se}_{2}$ & -0.285 & -0.318 & -1.864 & -0.453 & -7.674 & $1.13 \times 10^{19}$ \\
\hline $\mathrm{Se}, \mathrm{O}_{2} \mathrm{Zr}, \mathrm{Cu}_{3} \mathrm{Se}_{2}, \mathrm{Bi}_{2} \mathrm{O}_{3}$ & -0.865 & -0.62 & -1.435 & 0.0 & -8.532 & $7.5 \times 10^{19}$ \\
\hline $\mathrm{Se}, \mathrm{Bi}_{2} \mathrm{O}_{2} \mathrm{Se}, \mathrm{O}_{2} \mathrm{Zr}, \mathrm{Bi}_{2} \mathrm{Se}_{3}$ & -0.378 & -0.708 & -1.835 & 0.0 & -7.732 & $1.25 \times 10^{20}$ \\
\hline $\mathrm{Se}, \mathrm{Bi}_{2} \mathrm{O}_{2} \mathrm{Se}, \mathrm{O}_{2} \mathrm{Zr}, \mathrm{Bi}_{2} \mathrm{O}_{3}$ & -0.602 & -0.708 & -1.61 & 0.0 & -8.182 & $1.26 \times 10^{20}$ \\
\hline $\mathrm{Se}, \mathrm{O}_{2} \mathrm{Zr}, \mathrm{Cu}_{3} \mathrm{Se}_{2}, \mathrm{Bi}_{2} \mathrm{Se}_{3}$ & -0.378 & -0.62 & -1.923 & 0.0 & -7.557 & $7.36 \times 10^{19}$ \\
\hline
\end{tabular}

Table S21: Chemical potentials $\Delta \mu_{\mathrm{i}}$ (in eV) in all phase regions of the quinary Bi-Cu-Se-O-Zr phase space that are in equilibrium with $\mathrm{BiCuSeO}$. The corresponding charge carrier concentration in each phase region, as determined by charge neutrality at the typical synthesis temperature of $973 \mathrm{~K}$, is listed. 


\section{Phase Equilibriua of Hf-Doped BiCuSeO}

\begin{tabular}{|c|c|c|c|c|c|c|}
\hline Equilibrium Phases & $\Delta \mu_{\mathrm{Bi}}$ & $\Delta \mu_{\mathrm{Cu}}$ & $\Delta \mu_{\mathrm{Hf}}$ & $\Delta \mu_{\mathrm{O}}$ & $\Delta \mu_{\mathrm{Se}}$ & $p-n\left(\mathrm{~cm}^{-3}\right)$ \\
\hline $\mathrm{Se}, \mathrm{HfO}_{2}, \mathrm{Cu}_{3} \mathrm{Se}_{2}, \mathrm{Bi}_{2} \mathrm{Se}_{3}$ & -0.378 & -0.62 & -8.0 & -1.923 & 0.0 & $7.36 \times 10^{19}$ \\
\hline $\mathrm{Se}, \mathrm{Bi}_{2} \mathrm{O}_{2} \mathrm{Se}, \mathrm{HfO}_{2}, \mathrm{Bi}_{8} \mathrm{Hf}_{8} \mathrm{O}_{28}$ & -0.517 & -0.708 & -8.454 & -1.695 & 0.0 & $1.25 \times 10^{20}$ \\
\hline $\mathrm{Se}, \mathrm{Bi}_{2} \mathrm{O}_{2} \mathrm{Se}, \mathrm{Bi}_{2} \mathrm{O}_{3}, \mathrm{Bi}_{8} \mathrm{Hf}_{8} \mathrm{O}_{28}$ & -0.603 & -0.708 & -8.668 & -1.61 & 0.0 & $1.26 \times 10^{20}$ \\
\hline $\mathrm{Se}, \mathrm{Bi}_{2} \mathrm{O}_{2} \mathrm{Se}, \mathrm{HfO}_{2}, \mathrm{Bi}_{2} \mathrm{Se}_{3}$ & -0.378 & -0.708 & -8.175 & -1.835 & 0.0 & $1.25 \times 10^{20}$ \\
\hline $\mathrm{Se}, \mathrm{HfO}_{2}, \mathrm{Cu}_{3} \mathrm{Se}_{2}, \mathrm{Bi}_{8} \mathrm{Hf}_{8} \mathrm{O}_{28}$ & -0.78 & -0.62 & -8.805 & -1.52 & 0.0 & $7.48 \times 10^{19}$ \\
\hline $\mathrm{Se}, \mathrm{Cu}_{3} \mathrm{Se}_{2}, \mathrm{Bi}_{2} \mathrm{O}_{3}, \mathrm{Bi}_{8} \mathrm{Hf}_{8} \mathrm{O}_{28}$ & -0.865 & -0.62 & -9.018 & -1.435 & 0.0 & $7.48 \times 10^{19}$ \\
\hline $\mathrm{Bi}, \mathrm{Bi}_{2} \mathrm{O}_{2} \mathrm{Se}, \mathrm{HfO}_{2}, \mathrm{Bi}_{2} \mathrm{Se}_{3}$ & 0.0 & -0.582 & -7.672 & -2.087 & -0.252 & $5.4 \times 10^{19}$ \\
\hline $\mathrm{Bi}, \mathrm{Cu}_{2} \mathrm{Se}, \mathrm{Cu}_{2} \mathrm{O}, \mathrm{HfO}_{2}$ & 0.0 & -0.223 & -7.737 & -2.054 & -0.643 & $5.11 \times 10^{18}$ \\
\hline $\mathrm{Bi}, \mathrm{Cu}_{2} \mathrm{O}, \mathrm{HfO}_{2}, \mathrm{Bi}_{8} \mathrm{Hf}_{8} \mathrm{O}_{28}$ & 0.0 & -0.23 & -7.765 & -2.04 & -0.65 & $5.29 \times 10^{18}$ \\
\hline $\mathrm{Bi}, \mathrm{Cu}_{2} \mathrm{O}, \mathrm{Bi}_{2} \mathrm{O}_{3}, \mathrm{Bi}_{8} \mathrm{Hf}_{8} \mathrm{O}_{28}$ & 0.0 & -0.244 & -7.864 & -2.012 & -0.664 & $5.61 \times 10^{18}$ \\
\hline $\mathrm{Bi}, \mathrm{Bi}_{2} \mathrm{O}_{2} \mathrm{Se}, \mathrm{Bi}_{2} \mathrm{O}_{3}, \mathrm{Bi}_{8} \mathrm{Hf}_{8} \mathrm{O}_{28}$ & 0.0 & -0.507 & -7.864 & -2.012 & -0.402 & $3.44 \times 10^{19}$ \\
\hline $\mathrm{Bi}, \mathrm{Bi}_{2} \mathrm{O}_{2} \mathrm{Se}, \mathrm{HfO}_{2}, \mathrm{Bi}_{8} \mathrm{Hf}_{8} \mathrm{O}_{28}$ & 0.0 & -0.535 & -7.765 & -2.04 & -0.345 & $4.14 \times 10^{19}$ \\
\hline $\mathrm{Bi}, \mathrm{HfO}_{2}, \mathrm{Cu}_{3} \mathrm{Se}_{2}, \mathrm{Bi}_{2} \mathrm{Se}_{3}$ & 0.0 & -0.452 & -7.413 & -2.216 & -0.252 & $2.33 \times 10^{19}$ \\
\hline $\mathrm{Bi}, \mathrm{Cu}_{2} \mathrm{Se}, \mathrm{HfO}_{2}, \mathrm{Cu}_{3} \mathrm{Se}_{2}$ & 0.0 & -0.318 & -7.547 & -2.149 & -0.453 & $1.1 \times 10^{19}$ \\
\hline $\mathrm{Cu}_{2} \mathrm{O}, \mathrm{Cu}_{3} \mathrm{Se}_{2}, \mathrm{Bi}_{2} \mathrm{O}_{3}, \mathrm{Bi}_{8} \mathrm{Hf}_{8} \mathrm{O}_{28}$ & -0.603 & -0.445 & -8.668 & -1.61 & -0.262 & $2.6 \times 10^{19}$ \\
\hline $\mathrm{Cu}_{2} \mathrm{O}, \mathrm{HfO}_{2}, \mathrm{Cu}_{3} \mathrm{Se}_{2}, \mathrm{Bi}_{8} \mathrm{Hf}_{8} \mathrm{O}_{28}$ & -0.39 & -0.36 & -8.284 & -1.78 & -0.39 & $1.51 \times 10^{19}$ \\
\hline $\mathrm{Cu}_{2} \mathrm{Se}, \mathrm{Cu}_{2} \mathrm{O}, \mathrm{HfO}_{2}, \mathrm{Cu}_{3} \mathrm{Se}_{2}$ & -0.285 & -0.318 & -8.117 & -1.864 & -0.453 & $1.13 \times 10^{19}$ \\
\hline
\end{tabular}

Table S22: Chemical potentials $\Delta \mu_{\mathrm{i}}$ (in eV) in all phase regions of the quinary Bi-Cu-Se-O-Hf phase space that are in equilibrium with $\mathrm{BiCuSeO}$. The corresponding charge carrier concentration in each phase region, as determined by charge neutrality at the typical synthesis temperature of $973 \mathrm{~K}$, is listed. 


\section{Phase Equilibria of F-Doped BiCuSeO}

\begin{tabular}{|c|c|c|c|c|c|c|}
\hline Equilibrium Phases & $\Delta \mu_{\mathrm{Bi}}$ & $\Delta \mu_{\mathrm{Cu}}$ & $\Delta \mu_{\mathrm{F}}$ & $\Delta \mu_{\mathrm{O}}$ & $\Delta \mu_{\mathrm{Se}}$ & $p-n\left(\mathrm{~cm}^{-3}\right)$ \\
\hline $\mathrm{Cu}_{2} \mathrm{O}, \mathrm{Cu}_{3} \mathrm{Se}_{2}, \mathrm{Bi}_{2} \mathrm{O}_{3}, \mathrm{BiFO}$ & -0.632 & -0.465 & -3.449 & -1.601 & -0.25 & $2.62 \times 10^{19}$ \\
\hline $\mathrm{Cu}_{3} \mathrm{Se}_{2}, \mathrm{Bi}_{7} \mathrm{~F}_{11} \mathrm{O}_{5}, \mathrm{Cu}_{2} \mathrm{Se}, \mathrm{BiFO}$ & -0.263 & -0.349 & -3.507 & -1.913 & -0.423 & $8.12 \times 10^{18}$ \\
\hline $\mathrm{Cu}_{2} \mathrm{O}, \mathrm{Cu}_{3} \mathrm{Se}_{2}, \mathrm{Cu}_{2} \mathrm{Se}, \mathrm{BiFO}$ & -0.343 & -0.349 & -3.507 & -1.832 & -0.423 & $9.53 \times 10^{18}$ \\
\hline $\mathrm{Bi}, \mathrm{Cu}_{3} \mathrm{Se}_{2}, \mathrm{Bi}_{7} \mathrm{~F}_{11} \mathrm{O}_{5}, \mathrm{Cu}_{2} \mathrm{Se}$ & 0.0 & -0.349 & -3.555 & -2.176 & -0.423 & $2.99 \times 10^{18}$ \\
\hline $\mathrm{Bi}, \mathrm{Cu}_{3} \mathrm{Se}_{2}, \mathrm{Bi}_{7} \mathrm{~F}_{11} \mathrm{O}_{5}, \mathrm{Bi}_{2} \mathrm{Se}_{3}$ & 0.0 & -0.46 & -3.53 & -2.231 & -0.256 & $3.82 \times 10^{18}$ \\
\hline $\mathrm{Bi}, \mathrm{Bi}_{7} \mathrm{~F}_{11} \mathrm{O}_{5}, \mathrm{Bi}_{2} \mathrm{O}_{2} \mathrm{Se}, \mathrm{BiFO}$ & 0.0 & -0.583 & -3.595 & -2.088 & -0.277 & $2.61 \times 10^{19}$ \\
\hline $\mathrm{Bi}, \mathrm{Bi}_{2} \mathrm{O}_{3}, \mathrm{Bi}_{2} \mathrm{O}_{2} \mathrm{Se}, \mathrm{BiFO}$ & 0.0 & -0.518 & -3.66 & -2.023 & -0.408 & $2.77 \times 10^{19}$ \\
\hline $\mathrm{Bi}, \mathrm{Bi}_{7} \mathrm{~F}_{11} \mathrm{O}_{5}, \mathrm{Cu}_{2} \mathrm{Se}, \mathrm{BiFO}$ & 0.0 & -0.262 & -3.595 & -2.088 & -0.598 & $2.93 \times 10^{18}$ \\
\hline $\mathrm{Bi}, \mathrm{Cu}_{2} \mathrm{O}, \mathrm{Cu}_{2} \mathrm{Se}, \mathrm{BiFO}$ & 0.0 & -0.235 & -3.621 & -2.061 & -0.652 & $2.61 \times 10^{18}$ \\
\hline $\mathrm{Bi}, \mathrm{Cu}_{2} \mathrm{O}, \mathrm{Bi}_{2} \mathrm{O}_{3}, \mathrm{BiFO}$ & 0.0 & -0.254 & -3.66 & -2.023 & -0.671 & $3.59 \times 10^{18}$ \\
\hline $\mathrm{Bi}, \mathrm{Bi}_{7} \mathrm{~F}_{11} \mathrm{O}_{5}, \mathrm{Bi}_{2} \mathrm{O}_{2} \mathrm{Se}, \mathrm{Bi}_{2} \mathrm{Se}_{3}$ & 0.0 & -0.593 & -3.59 & -2.098 & -0.256 & $2.59 \times 10^{19}$ \\
\hline $\mathrm{Se}, \mathrm{Cu}_{3} \mathrm{Se}_{2}, \mathrm{Bi}_{7} \mathrm{~F}_{11} \mathrm{O}_{5}, \mathrm{BiFO}$ & -0.686 & -0.631 & -3.366 & -1.631 & 0.0 & $7 \times 10^{19}$ \\
\hline $\mathrm{Se}, \mathrm{Cu}_{3} \mathrm{Se}_{2}, \mathrm{Bi}_{2} \mathrm{O}_{3}, \mathrm{BiFO}$ & -0.882 & -0.631 & -3.366 & -1.435 & 0.0 & $7.77 \times 10^{19}$ \\
\hline $\mathrm{Se}, \mathrm{Bi}_{7} \mathrm{~F}_{11} \mathrm{O}_{5}, \mathrm{Bi}_{2} \mathrm{O}_{2} \mathrm{Se}, \mathrm{Bi}_{2} \mathrm{Se}_{3}$ & -0.385 & -0.722 & -3.462 & -1.842 & 0.0 & $9.44 \times 10^{19}$ \\
\hline $\mathrm{Se}, \mathrm{Bi}_{2} \mathrm{O}_{3}, \mathrm{Bi}_{2} \mathrm{O}_{2} \mathrm{Se}, \mathrm{BiFO}$ & -0.611 & -0.722 & -3.456 & -1.615 & 0.0 & $1.31 \times 10^{20}$ \\
\hline $\mathrm{Se}, \mathrm{Bi}_{7} \mathrm{~F}_{11} \mathrm{O}_{5}, \mathrm{Bi}_{2} \mathrm{O}_{2} \mathrm{Se}, \mathrm{BiFO}$ & -0.415 & -0.722 & -3.456 & -1.811 & 0.0 & $1.01 \times 10^{20}$ \\
\hline $\mathrm{Se}, \mathrm{Cu}_{3} \mathrm{Se}_{2}, \mathrm{Bi}_{7} \mathrm{~F}_{11} \mathrm{O}_{5}, \mathrm{Bi}_{2} \mathrm{Se}_{3}$ & -0.385 & -0.631 & -3.421 & -1.932 & 0.0 & $3.23 \times 10^{19}$ \\
\hline
\end{tabular}

Table S23: Chemical potentials $\Delta \mu_{\mathrm{i}}$ (in eV) in all phase regions of the quinary Bi-Cu-Se-O-F phase space that are in equilibrium with $\mathrm{BiCuSeO}$. The corresponding charge carrier concentration in each phase region, as determined by charge neutrality at the typical synthesis temperature of $973 \mathrm{~K}$, is listed. 


\section{Phase Equilibria of Cl-Doped BiCuSeO}

\begin{tabular}{|c|c|c|c|c|c|c|}
\hline Equilibrium Phases & $\Delta \mu_{\mathrm{Bi}}$ & $\Delta \mu_{\mathrm{Cl}}$ & $\Delta \mu_{\mathrm{Cu}}$ & $\Delta \mu_{\mathrm{O}}$ & $\Delta \mu_{\mathrm{Se}}$ & $p-n\left(\mathrm{~cm}^{-3}\right)$ \\
\hline $\mathrm{Se}, \mathrm{BiClO}, \mathrm{Cu}_{3} \mathrm{Se}_{2}, \mathrm{Bi}_{2} \mathrm{Se}_{3}$ & -0.378 & -1.43 & -0.62 & -1.923 & 0.0 & $3.32 \times 10^{19}$ \\
\hline $\mathrm{Se}, \mathrm{Bi}_{2} \mathrm{O}_{2} \mathrm{Se}, \mathrm{Bi}_{2} \mathrm{O}_{3}, \mathrm{Bi}_{48} \mathrm{Cl}_{20} \mathrm{O}_{62}$ & -0.603 & -1.627 & -0.708 & -1.61 & 0.0 & $1.05 \times 10^{20}$ \\
\hline $\mathrm{Se}, \mathrm{BiClO}, \mathrm{Bi}_{2} \mathrm{O}_{2} \mathrm{Se}, \mathrm{Bi}_{48} \mathrm{Cl}_{20} \mathrm{O}_{62}$ & -0.446 & -1.518 & -0.708 & -1.767 & 0.0 & $7.95 \times 10^{19}$ \\
\hline $\mathrm{Se}, \mathrm{BiClO}, \mathrm{Bi}_{2} \mathrm{O}_{2} \mathrm{Se}, \mathrm{Bi}_{2} \mathrm{Se}_{3}$ & -0.378 & -1.518 & -0.708 & -1.835 & 0.0 & $7.92 \times 10^{19}$ \\
\hline $\mathrm{Se}, \mathrm{BiClO}, \mathrm{Cu}_{3} \mathrm{Se}_{2}, \mathrm{Bi}_{48} \mathrm{Cl}_{20} \mathrm{O}_{62}$ & -0.708 & -1.43 & -0.62 & -1.592 & 0.0 & $3.34 \times 10^{19}$ \\
\hline $\mathrm{Se}, \mathrm{Cu}_{3} \mathrm{Se}_{2}, \mathrm{Bi}_{2} \mathrm{O}_{3}, \mathrm{Bi}_{48} \mathrm{Cl}_{20} \mathrm{O}_{62}$ & -0.865 & -1.54 & -0.62 & -1.435 & 0.0 & $5.15 \times 10^{19}$ \\
\hline $\mathrm{Bi}, \mathrm{BiClO}, \mathrm{Bi}_{2} \mathrm{O}_{2} \mathrm{Se}, \mathrm{Bi}_{2} \mathrm{Se}_{3}$ & 0.0 & -1.643 & -0.582 & -2.087 & -0.252 & $2.18 \times 10^{19}$ \\
\hline $\mathrm{Bi}, \mathrm{BiClO}, \mathrm{Bi}_{2} \mathrm{O}_{2} \mathrm{Se}, \mathrm{Bi}_{48} \mathrm{Cl}_{20} \mathrm{O}_{62}$ & 0.0 & -1.666 & -0.559 & -2.064 & -0.297 & $1.71 \times 10^{19}$ \\
\hline $\mathrm{Bi}, \mathrm{Bi}_{2} \mathrm{O}_{2} \mathrm{Se}, \mathrm{Bi}_{2} \mathrm{O}_{3}, \mathrm{Bi}_{48} \mathrm{Cl}_{20} \mathrm{O}_{62}$ & 0.0 & -1.828 & -0.507 & -2.012 & -0.402 & $1.66 \times 10^{19}$ \\
\hline $\mathrm{Bi}, \mathrm{Cu}_{2} \mathrm{Se}, \mathrm{Cu}_{2} \mathrm{O}, \mathrm{Bi}_{48} \mathrm{Cl}_{20} \mathrm{O}_{62}$ & 0.0 & -1.697 & -0.223 & -2.054 & -0.643 & $-2.32 \times 10^{18}$ \\
\hline $\mathrm{Bi}, \mathrm{Cu}_{2} \mathrm{Se}, \mathrm{BiClO}, \mathrm{Bi}_{48} \mathrm{Cl}_{20} \mathrm{O}_{62}$ & 0.0 & -1.666 & -0.233 & -2.064 & -0.623 & $-2.35 \times 10^{18}$ \\
\hline $\mathrm{Bi}, \mathrm{Cu}_{2} \mathrm{O}, \mathrm{Bi}_{2} \mathrm{O}_{3}, \mathrm{Bi}_{48} \mathrm{Cl}_{20} \mathrm{O}_{62}$ & 0.0 & -1.828 & -0.244 & -2.012 & -0.664 & $-4.58 \times 10^{17}$ \\
\hline $\mathrm{Bi}, \mathrm{BiClO}, \mathrm{Cu}_{3} \mathrm{Se}_{2}, \mathrm{Bi}_{2} \mathrm{Se}_{3}$ & 0.0 & -1.514 & -0.452 & -2.216 & -0.252 & $4.83 \times 10^{18}$ \\
\hline $\mathrm{Bi}, \mathrm{Cu}_{2} \mathrm{Se}, \mathrm{BiClO}, \mathrm{Cu}_{3} \mathrm{Se}_{2}$ & 0.0 & -1.581 & -0.318 & -2.149 & -0.453 & $9.94 \times 10^{14}$ \\
\hline $\mathrm{Cu}_{2} \mathrm{O}, \mathrm{Cu}_{3} \mathrm{Se}_{2}, \mathrm{Bi}_{2} \mathrm{O}_{3}, \mathrm{Bi}_{48} \mathrm{Cl}_{20} \mathrm{O}_{62}$ & -0.603 & -1.627 & -0.445 & -1.61 & -0.262 & $8.51 \times 10^{18}$ \\
\hline $\mathrm{Cu}_{2} \mathrm{Se}, \mathrm{BiClO}, \mathrm{Cu}_{3} \mathrm{Se}_{2}, \mathrm{Bi}_{48} \mathrm{Cl}_{20} \mathrm{O}_{62}$ & -0.255 & -1.581 & -0.318 & -1.894 & -0.453 & $3.5 \times 10^{16}$ \\
\hline $\mathrm{Cu}_{2} \mathrm{Se}, \mathrm{Cu}_{2} \mathrm{O}, \mathrm{Cu}_{3} \mathrm{Se}_{2}, \mathrm{Bi}_{48} \mathrm{Cl}_{20} \mathrm{O}_{62}$ & -0.285 & -1.602 & -0.318 & -1.864 & -0.453 & $3.02 \times 10^{17}$ \\
\hline
\end{tabular}

Table S24: Chemical potentials $\Delta \mu_{\mathrm{i}}$ (in eV) in all phase regions of the quinary Bi-Cu-Se-O-Cl phase space that are in equilibrium with $\mathrm{BiCuSeO}$. The corresponding charge carrier concentration in each phase region, as determined by charge neutrality at the typical synthesis temperature of $973 \mathrm{~K}$, is listed. 


\section{Phase Equilibria of Br-Doped BiCuSeO}

\begin{tabular}{|c|c|c|c|c|c|c|}
\hline Equilibrium Phases & $\Delta \mu_{\mathrm{Bi}}$ & $\Delta \mu_{\mathrm{Br}}$ & $\Delta \mu_{\mathrm{Cu}}$ & $\Delta \mu_{\mathrm{O}}$ & $\Delta \mu_{\mathrm{Se}}$ & $p-n\left(\mathrm{~cm}^{-3}\right)$ \\
\hline $\mathrm{Bi}_{4} \mathrm{Br}_{2} \mathrm{O}_{5}, \mathrm{Cu}_{2} \mathrm{O}, \mathrm{Cu}_{3} \mathrm{Se}_{2}, \mathrm{Bi}_{2} \mathrm{O}_{3}$ & -0.603 & -1.082 & -0.445 & -1.61 & -0.262 & $1.02 \times 10^{19}$ \\
\hline $\mathrm{Bi}_{4} \mathrm{Br}_{2} \mathrm{O}_{5}, \mathrm{Cu}_{3} \mathrm{Se}_{2}, \mathrm{Bi}_{2} \mathrm{O}_{3}, \mathrm{Bi}_{6} \mathrm{Br}_{2} \mathrm{O}_{14} \mathrm{Se}_{3}$ & -0.833 & -1.006 & -0.599 & -1.456 & -0.032 & $4.75 \times 10^{19}$ \\
\hline $\mathrm{Bi}_{4} \mathrm{Br}_{2} \mathrm{O}_{5}, \mathrm{Cu}_{2} \mathrm{Se}, \mathrm{Cu}_{3} \mathrm{Se}_{2}, \mathrm{BiBrO}$ & -0.152 & -1.016 & -0.318 & -1.997 & -0.453 & $2.06 \times 10^{17}$ \\
\hline $\mathrm{Bi}_{4} \mathrm{Br}_{2} \mathrm{O}_{5}, \mathrm{Cu}_{2} \mathrm{O}, \mathrm{Cu}_{2} \mathrm{Se}, \mathrm{Cu}_{3} \mathrm{Se}_{2}$ & -0.285 & -1.082 & -0.318 & -1.864 & -0.453 & $1.07 \times 10^{18}$ \\
\hline $\mathrm{Bi}, \mathrm{Cu}_{2} \mathrm{Se}, \mathrm{Cu}_{3} \mathrm{Se}_{2}, \mathrm{BiBrO}$ & 0.0 & -1.016 & -0.318 & -2.149 & -0.453 & $1.92 \times 10^{17}$ \\
\hline $\mathrm{Bi}, \mathrm{Cu}_{3} \mathrm{Se}_{2}, \mathrm{BiBrO}, \mathrm{Bi}_{2} \mathrm{Se}_{3}$ & 0.0 & -0.949 & -0.452 & -2.216 & -0.252 & $5.31 \times 10^{18}$ \\
\hline $\mathrm{Bi}, \mathrm{Bi}_{4} \mathrm{Br}_{2} \mathrm{O}_{5}, \mathrm{Bi}_{2} \mathrm{O}_{2} \mathrm{Se}, \mathrm{Bi}_{2} \mathrm{O}_{3}$ & 0.0 & -1.283 & -0.507 & -2.012 & -0.402 & $1.94 \times 10^{19}$ \\
\hline $\mathrm{Bi}, \mathrm{Bi}_{4} \mathrm{Br}_{2} \mathrm{O}_{5}, \mathrm{Bi}_{2} \mathrm{O}_{2} \mathrm{Se}, \mathrm{Bi}_{2} \mathrm{Se}_{3}$ & 0.0 & -1.096 & -0.582 & -2.087 & -0.252 & $2.57 \times 10^{19}$ \\
\hline $\mathrm{Bi}, \mathrm{Bi}_{4} \mathrm{Br}_{2} \mathrm{O}_{5}, \mathrm{BiBrO}, \mathrm{Bi}_{2} \mathrm{Se}_{3}$ & 0.0 & -1.067 & -0.57 & -2.098 & -0.252 & $2.08 \times 10^{19}$ \\
\hline $\mathrm{Bi}, \mathrm{Bi}_{4} \mathrm{Br}_{2} \mathrm{O}_{5}, \mathrm{Cu}_{2} \mathrm{O}, \mathrm{Bi}_{2} \mathrm{O}_{3}$ & 0.0 & -1.283 & -0.244 & -2.012 & -0.664 & $-2.62 \times 10^{16}$ \\
\hline $\mathrm{Bi}, \mathrm{Bi}_{4} \mathrm{Br}_{2} \mathrm{O}_{5}, \mathrm{Cu}_{2} \mathrm{O}, \mathrm{Cu}_{2} \mathrm{Se}$ & 0.0 & -1.177 & -0.223 & -2.054 & -0.643 & $-1.37 \times 10^{18}$ \\
\hline $\mathrm{Bi}, \mathrm{Bi}_{4} \mathrm{Br}_{2} \mathrm{O}_{5}, \mathrm{Cu}_{2} \mathrm{Se}, \mathrm{BiBrO}$ & 0.0 & -1.067 & -0.267 & -2.098 & -0.554 & $-1.07 \times 10^{18}$ \\
\hline $\mathrm{Se}, \mathrm{Bi}_{4} \mathrm{Br}_{2} \mathrm{O}_{5}, \mathrm{Bi}_{2} \mathrm{O}_{3}, \mathrm{Bi}_{6} \mathrm{Br}_{2} \mathrm{O}_{14} \mathrm{Se}_{3}$ & -0.809 & -1.014 & -0.639 & -1.472 & 0.0 & $6.63 \times 10^{19}$ \\
\hline $\mathrm{Se}, \mathrm{Cu}_{3} \mathrm{Se}_{2}, \mathrm{Bi}_{2} \mathrm{O}_{3}, \mathrm{Bi}_{6} \mathrm{Br}_{2} \mathrm{O}_{14} \mathrm{Se}_{3}$ & -0.865 & -1.108 & -0.62 & -1.435 & 0.0 & $6.84 \times 10^{19}$ \\
\hline $\mathrm{Se}, \mathrm{Bi}_{4} \mathrm{Br}_{2} \mathrm{O}_{5}, \mathrm{Cu}_{3} \mathrm{Se}_{2}, \mathrm{BiBrO}$ & -0.605 & -0.865 & -0.62 & -1.695 & 0.0 & $3.58 \times 10^{19}$ \\
\hline $\mathrm{Se}, \mathrm{Bi}_{4} \mathrm{Br}_{2} \mathrm{O}_{5}, \mathrm{Cu}_{3} \mathrm{Se}_{2}, \mathrm{Bi}_{6} \mathrm{Br}_{2} \mathrm{O}_{14} \mathrm{Se}_{3}$ & -0.833 & -0.979 & -0.62 & -1.467 & 0.0 & $5.45 \times 10^{19}$ \\
\hline $\mathrm{Se}, \mathrm{Bi}_{4} \mathrm{Br}_{2} \mathrm{O}_{5}, \mathrm{BiBrO}, \mathrm{Bi}_{2} \mathrm{Se}_{3}$ & -0.378 & -0.941 & -0.696 & -1.847 & 0.0 & $7.51 \times 10^{19}$ \\
\hline $\mathrm{Se}, \mathrm{Bi}_{4} \mathrm{Br}_{2} \mathrm{O}_{5}, \mathrm{Bi}_{2} \mathrm{O}_{2} \mathrm{Se}, \mathrm{Bi}_{2} \mathrm{Se}_{3}$ & -0.378 & -0.97 & -0.708 & -1.835 & 0.0 & $8.8 \times 10^{19}$ \\
\hline Se, $\mathrm{Bi}_{4} \mathrm{Br}_{2} \mathrm{O}_{5}, \mathrm{Bi}_{2} \mathrm{O}_{2} \mathrm{Se}, \mathrm{Bi}_{2} \mathrm{O}_{3}$ & -0.603 & -1.083 & -0.708 & -1.61 & 0.0 & $1.11 \times 10^{20}$ \\
\hline $\mathrm{Se}, \mathrm{Cu}_{3} \mathrm{Se}_{2}, \mathrm{BiBrO}, \mathrm{Bi}_{2} \mathrm{Se}_{3}$ & -0.378 & -0.865 & -0.62 & -1.923 & 0.0 & $3.57 \times 10^{19}$ \\
\hline
\end{tabular}

Table S25: Chemical potentials $\Delta \mu_{\mathrm{i}}$ (in eV) in all phase regions of the quinary Bi-Cu-Se-O-Br phase space that are in equilibrium with $\mathrm{BiCuSeO}$. The corresponding charge carrier concentration in each phase region, as determined by charge neutrality at the typical synthesis temperature of $973 \mathrm{~K}$, is listed. 


\section{Phase Equilibria of I-Doped BiCuSeO}

\begin{tabular}{|c|c|c|c|c|c|c|}
\hline Equilibrium Phases & $\Delta \mu_{\mathrm{Bi}}$ & $\Delta \mu_{\mathrm{Cu}}$ & $\Delta \mu_{\mathrm{I}}$ & $\Delta \mu_{\mathrm{O}}$ & $\Delta \mu_{\mathrm{Se}}$ & $p-n\left(\mathrm{~cm}^{-3}\right)$ \\
\hline $\mathrm{Se}, \mathrm{Bi}_{4} \mathrm{I}_{2} \mathrm{O}_{5}, \mathrm{Bi}_{2} \mathrm{O}_{2} \mathrm{Se}, \mathrm{Bi}_{2} \mathrm{O}_{3}$ & -0.602 & -0.708 & -0.547 & -1.61 & 0.0 & $1.24 \times 10^{20}$ \\
\hline $\mathrm{Se}, \mathrm{Bi}_{4} \mathrm{I}_{2} \mathrm{O}_{5}, \mathrm{Bi}_{2} \mathrm{O}_{2} \mathrm{Se}, \mathrm{Bi}_{2} \mathrm{Se}_{3}$ & -0.378 & -0.708 & -0.435 & -1.835 & 0.0 & $1.18 \times 10^{20}$ \\
\hline $\mathrm{Se}, \mathrm{BiIO}, \mathrm{Bi}_{4} \mathrm{I}_{2} \mathrm{O}_{5}, \mathrm{Bi}_{2} \mathrm{Se}_{3}$ & -0.378 & -0.685 & -0.379 & -1.857 & 0.0 & $9.84 \times 10^{19}$ \\
\hline $\mathrm{Se}, \mathrm{BiIO}, \mathrm{Cu}_{3} \mathrm{Se}_{2}, \mathrm{Bi}_{2} \mathrm{Se}_{3}$ & -0.378 & -0.62 & -0.314 & -1.923 & 0.0 & $6.1 \times 10^{19}$ \\
\hline $\mathrm{Se}, \mathrm{BiIO}, \mathrm{Bi}_{4} \mathrm{I}_{2} \mathrm{O}_{5}, \mathrm{Cu}_{3} \mathrm{Se}_{2}$ & -0.573 & -0.62 & -0.314 & -1.727 & 0.0 & $6.16 \times 10^{19}$ \\
\hline $\mathrm{Se}, \mathrm{Bi}_{4} \mathrm{I}_{2} \mathrm{O}_{5}, \mathrm{Cu}_{3} \mathrm{Se}_{2}, \mathrm{Bi}_{2} \mathrm{O}_{3}$ & -0.865 & -0.62 & -0.46 & -1.435 & 0.0 & $7.2 \times 10^{19}$ \\
\hline $\mathrm{Bi}, \mathrm{BiIO}, \mathrm{CuI}, \mathrm{Bi}_{2} \mathrm{Se}_{3}$ & 0.0 & -0.455 & -0.401 & -2.213 & -0.252 & $1.33 \times 10^{19}$ \\
\hline $\mathrm{Bi}, \mathrm{BiIO}, \mathrm{Bi}_{4} \mathrm{I}_{2} \mathrm{O}_{5}, \mathrm{Bi}_{2} \mathrm{Se}_{3}$ & 0.0 & -0.559 & -0.505 & -2.109 & -0.252 & $3.57 \times 10^{19}$ \\
\hline $\mathrm{Bi}, \mathrm{Bi}_{4} \mathrm{I}_{2} \mathrm{O}_{5}, \mathrm{Bi}_{2} \mathrm{O}_{2} \mathrm{Se}, \mathrm{Bi}_{2} \mathrm{Se}_{3}$ & 0.0 & -0.582 & -0.561 & -2.087 & -0.252 & $4.6 \times 10^{19}$ \\
\hline $\mathrm{Bi}, \mathrm{Cu}_{2} \mathrm{O}, \mathrm{Bi}_{4} \mathrm{I}_{2} \mathrm{O}_{5}, \mathrm{Bi}_{2} \mathrm{O}_{3}$ & 0.0 & -0.244 & 748 & -2.012 & -0.664 & $2.41 \times 10^{18}$ \\
\hline $\mathrm{Bi}, \mathrm{Bi}_{4} \mathrm{I}_{2} \mathrm{O}_{5}, \mathrm{Bi}_{2} \mathrm{O}_{2} \mathrm{Se}, \mathrm{Bi}_{2} \mathrm{O}_{3}$ & 0.0 & -0.507 & -0.748 & -2.012 & -0.402 & $3.1 \times 10^{19}$ \\
\hline $\mathrm{Bi}, \mathrm{BiIO}, \mathrm{Bi}_{4} \mathrm{I}_{2} \mathrm{O}_{5}, \mathrm{CuI}$ & 0.0 & -0.351 & -0.505 & -2.109 & -0.46 & $4.14 \times 10^{18}$ \\
\hline $\mathrm{Bi}, \mathrm{Cu}_{2} \mathrm{Se}, \mathrm{Cu}_{2} \mathrm{O}, \mathrm{Bi}_{4} \mathrm{I}_{2} \mathrm{O}_{5}$ & 0.0 & -0.223 & -0.642 & -2.054 & -0.643 & $9.13 \times 10^{17}$ \\
\hline $\mathrm{Bi}, \mathrm{Cu}_{2} \mathrm{Se}, \mathrm{Bi}_{4} \mathrm{I}_{2} \mathrm{O}_{5}, \mathrm{CuI}$ & 0.0 & -0.229 & -0.627 & -2.06 & -0.63 & $9.66 \times 10^{17}$ \\
\hline $\mathrm{Bi}, \mathrm{Cu}_{3} \mathrm{Se}_{2}, \mathrm{CuI}, \mathrm{Bi}_{2} \mathrm{Se}_{3}$ & 0.0 & -0.452 & -0.404 & -2.216 & -0.252 & $1.32 \times 10^{19}$ \\
\hline $\mathrm{Bi}, \mathrm{Cu}_{2} \mathrm{Se}, \mathrm{Cu}_{3} \mathrm{Se}_{2}, \mathrm{CuI}$ & 0.0 & -0.318 & -0.538 & -2.149 & -0.453 & $4.2 \times 10^{18}$ \\
\hline $\mathrm{BiIO}, \mathrm{Cu}_{3} \mathrm{Se}_{2}, \mathrm{CuI}, \mathrm{Bi}_{2} \mathrm{Se}_{3}$ & -0.027 & -0.464 & -0.392 & -2.195 & -0.234 & $1.47 \times 10^{19}$ \\
\hline $\mathrm{BiIO}, \mathrm{Bi}_{4} \mathrm{I}_{2} \mathrm{O}_{5}, \mathrm{Cu}_{3} \mathrm{Se}_{2}, \mathrm{CuI}$ & -0.339 & -0.464 & -0.392 & -1.883 & -0.234 & $1.5 \times 10^{19}$ \\
\hline $\mathrm{Cu}_{2} \mathrm{O}, \mathrm{Bi}_{4} \mathrm{I}_{2} \mathrm{O}_{5}, \mathrm{Cu}_{3} \mathrm{Se}_{2}, \mathrm{Bi}_{2} \mathrm{O}_{3}$ & -0.603 & -0.445 & -0.547 & -1.61 & -0.262 & $2.05 \times 10^{19}$ \\
\hline $\mathrm{Cu}_{2} \mathrm{Se}, \mathrm{Cu}_{2} \mathrm{O}, \mathrm{Bi}_{4} \mathrm{I}_{2} \mathrm{O}_{5}, \mathrm{Cu}_{3} \mathrm{Se}_{2}$ & -0.285 & -0.318 & -0.547 & -1.864 & -0.453 & $4.45 \times 10^{18}$ \\
\hline $\mathrm{Cu}_{2} \mathrm{Se}, \mathrm{Bi}_{4} \mathrm{I}_{2} \mathrm{O}_{5}, \mathrm{Cu}_{3} \mathrm{Se}_{2}, \mathrm{CuI}$ & -0.266 & -0.318 & -0.538 & -1.883 & -0.453 & $4.22 \times 10^{18}$ \\
\hline
\end{tabular}

Table S26: Chemical potentials $\Delta \mu_{\mathrm{i}}$ (in eV) in all phase regions of the quinary Bi-Cu-Se-O-I phase space that are in equilibrium with $\mathrm{BiCuSeO}$. The corresponding charge carrier concentration in each phase region, as determined by charge neutrality at the typical synthesis temperature of $973 \mathrm{~K}$, is listed. 


\section{References}

(1) Hiramatsu, H.; Yanagi, H.; Kamiya, T.; Ueda, K.; Hirano, M.; Hosono, H. Crystal structures, optoelectronic properties, and electronic structures of layered oxychalcogenides $\mathrm{MCuOCh}(\mathrm{M}=\mathrm{Bi}, \mathrm{La} ; \mathrm{Ch}=\mathrm{S}$, $\mathrm{Se}, \mathrm{Te})$ : effects of electronic configurations of $\mathrm{M}^{3+}$ ions. Chem. Mater. 2008, 20, 326 .

(2) Lany, S. Semiconductor thermochemistry in density functional calculations. Phys. Rev. B 2008, 78, 245207.

(3) Stevanović, V.; Lany, S.; Zhang, X.; Zunger, A. Correcting density functional theory for accurate predictions of compound enthalpies of formation: Fitted elemental-phase reference energies. Phys. Rev. B 2012, 85, 115104 . 